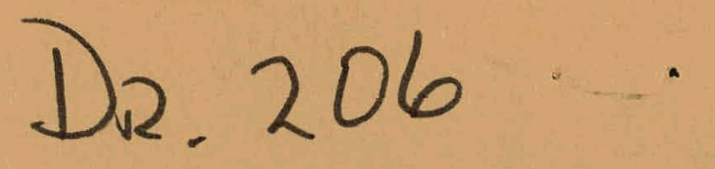

BNL 50703

\title{
THE ENERGY SITUATION IN \\ THE MID-ATLANTIC REGION
}

辛

\section{August 1977}

POLICY ANALYSIS DIVISION

NATIONAL CENTER FOR ANALYSIS OF ENERGY SYSTEMS BROOKHAVEN NATIONAL LABORATORY UPTON, NEW YORK 11973

Prepared for the UNITED STATES DEPARTMENT OF ENERGY 


\section{DISCLAIMER}

This report was prepared as an account of work sponsored by an agency of the United States Government. Neither the United States Government nor any agency Thereof, nor any of their employees, makes any warranty, express or implied, or assumes any legal liability or responsibility for the accuracy, completeness, or usefulness of any information, apparatus, product, or process disclosed, or represents that its use would not infringe privately owned rights. Reference herein to any specific commercial product, process, or service by trade name, trademark, manufacturer, or otherwise does not necessarily constitute or imply its endorsement, recommendation, or favoring by the United States Government or any agency thereof. The views and opinions of authors expressed herein do not necessarily state or reflect those of the United States Government or any agency thereof. 


\section{DISCLAIMER}

Portions of this document may be illegible in electronic image products. Images are produced from the best available original document. 
BNL 50703

UC-13

(General, Miscellaneous, and Progress Reports

(Nonnuclear) - TID-4500)

\section{THE ENERGY SITUATION IN THE MID-ATLANTIC REGION}

James S. Munson and Joel P. Brainard

with contributions by

Juan Divila, Charles L. Kelchner, John C. Lee

Martha McCoy, Eric Outwater, Philip F. Palmedo and Patricia Rice

\section{August 1977}

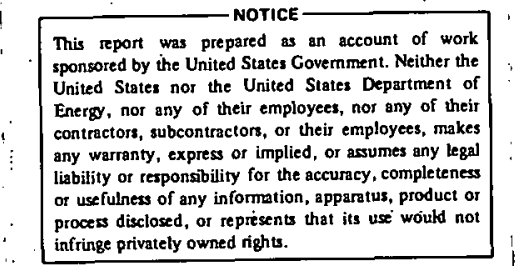

POLICY ANALYSIS DIVISION

NATIONAL CENTER FOR ANALYSIS OF ENERGY SYSTEMS BROOKHAVEN NATIONAL LABORATORY ASSOCIATED UNIVERSITIES, INC.

UNDER CONTRACT NO. EY-76-C-02-0016 WITH THE 
"The Department of Energy (DOE) is the successor to the Energy Research and Development Administration (ERDA) and all references to ERDA herein shall be deemed to refer to DOE."

\section{NOT I C E}

This report was prepared as an accouni of work sponsored by die United Blates Government. Neither the United States nor the United States Department of Energy (DOE), nor any of their employees, nor any of their contractors, subcontractors, or their employees, makes any warranty, express or implied, or assumes any legal liability or responsibility for the accuracy, completeness or usefulness of any information, apparatus, product or process disclosed, or represents that its use would not infringe privately owned rights.

Printed in the United States of America

Available from

National Technical Information Service

U.S. Department of Commerce

5285 Port Royal Road

Springfield, VA 22161

Price: Printed Copy $\$ 10.75$; Microfiche $\$ 3.00$ 


\section{ABSTRACT}

This report presents a review of the energy situation in the MidAtlantic Region. It describes the patterns of energy production; supply and demand by state and compares these to national and regional averages. It presents a picture of existing energy and environmental interactions and a view of potential energy and environmental conflicts. A review of the major issues by energy sector is included as is a description of the existing energy actors and major energy programs. 


\section{Acknowledgements}

A large number of individuals and groups contributed to the preparation of this report. In all of the states members of government were generous and frank in their discussion of energy issues. Juan Davila in Puerto Rico, Pat Rice at Oak Ridge National Laboratory, Martha McCoy and John Lee at Brookhaven National Laboratory, Charles L. Kelchner of ERDA, and Eric Outwater (Reg. II) and Michael J. Chern (Reg. III) of the regional EPA offices prepared material included in this document. Eugene Gleason of the Northeastern Legislative Conferenee and Hugh Montgomery of the Appalachian Regional Commission were of great help in providing data and interpretations of these data.

At Brookhaven, Carl Thien and Beverly Goldstein prepared an extensive compilation of newspaper clippings that was useful in defining recent trends and local concerns. Robert Stern, Donna Visone, Georgia Irving and Adele Hough contributed invaluably to the preparation of this report. 
Table of Contents

Page

Chapter I Introduction . . . . . . . . . . . . . . . . . 1

Chapter II Comparison of 1975 Energy Supply and Demand . . . . . . . . 2

Chapter III Energy Supply and Demand. . . . . . . . . . . . . 15

Introduction ..................... . . . 15

District of Columbia . . . . . . . . . . . . . 15

Delaware ........................ 21

Maryland . . . . . . . . . . . . . . . . . 26

New Jersey . . . . . . . . . . . . . . . . . 31

New York...................... 36

Ohio . . . . . . . . . . . . . . . . . . . 41

Pennsylvania . . . . . . . . . . . . . . . . . . 47

Puerto Rico. . . . . . . . . . . . . . . . . . . . 52

Virginia . . . . . . . . . . . . . . . . . . . . . 59

Virgin Islands... . . . . . . . . . . . . . . . . 65

United States. . . . . . . . . . . . . . . . . 74

References and Notes................... 78

Chapter IV Environmental Quality and Concerns . . . . . . . . . . 80

Delaware ...................... 83

Maryland ....................... 84

New Jersey . . . . . . . . . . . . . . . . . . . 84

New York . . . . . . . . . . . . . . . . . . 86

Pennsylvania . . . . . . . . . . . . . . . . . . 87

Virginia . . . . . . . . . . . . . . . . . . . . 88

West Virginia. . . . . . . . . . . . . . . . . 89

Puerto Rico......................... 90

Virgin Islands . . . . . . . . . . . . . . . . . . 91

Chapter V Energy Issues and Actions. . . . . . . . . . . . . . . 92

Petroleum. . . . . . . . . . . . . . . . 95

Natural Gas ...................... . . . . 99

Coal ........................... 102

Nuclear. . . . . . . . . . . . . . . . 107

Solar, Wind, Solid Waste . . . . . . . . . . . . . . 112

Alternatives . . . . . . . . . . . . . . . . 115

Conservation . . . . . . . . . . . . . . . . . . . 117

Utility Regulation, Rates. . . . . . . . . . . . . 128

Chapter VI The Actors. . . . . . . . . . . . . . . . . 129

The Governors. . . . . . . . . . . . . . . . . . 130

State Agencies . . . . . . . . . . . . . . . . . . . 139

State Legislatures . . . . . . . . . . . . . . . 143 
Regional Groups. .. . . . . . . . . . . . . . . . . $\frac{\text { Page }}{151}$

Regional Organizations. . . . . . . . . . . . . . 155

The Utilities . . . . . . . . . . . . . . . . . . . 156

The Industries. . . . . . . . . . . . . . . . . . 160

Appendix A State Agencies with Energy Related Functions . . . . . . . 165 
"The Region of Analysis"

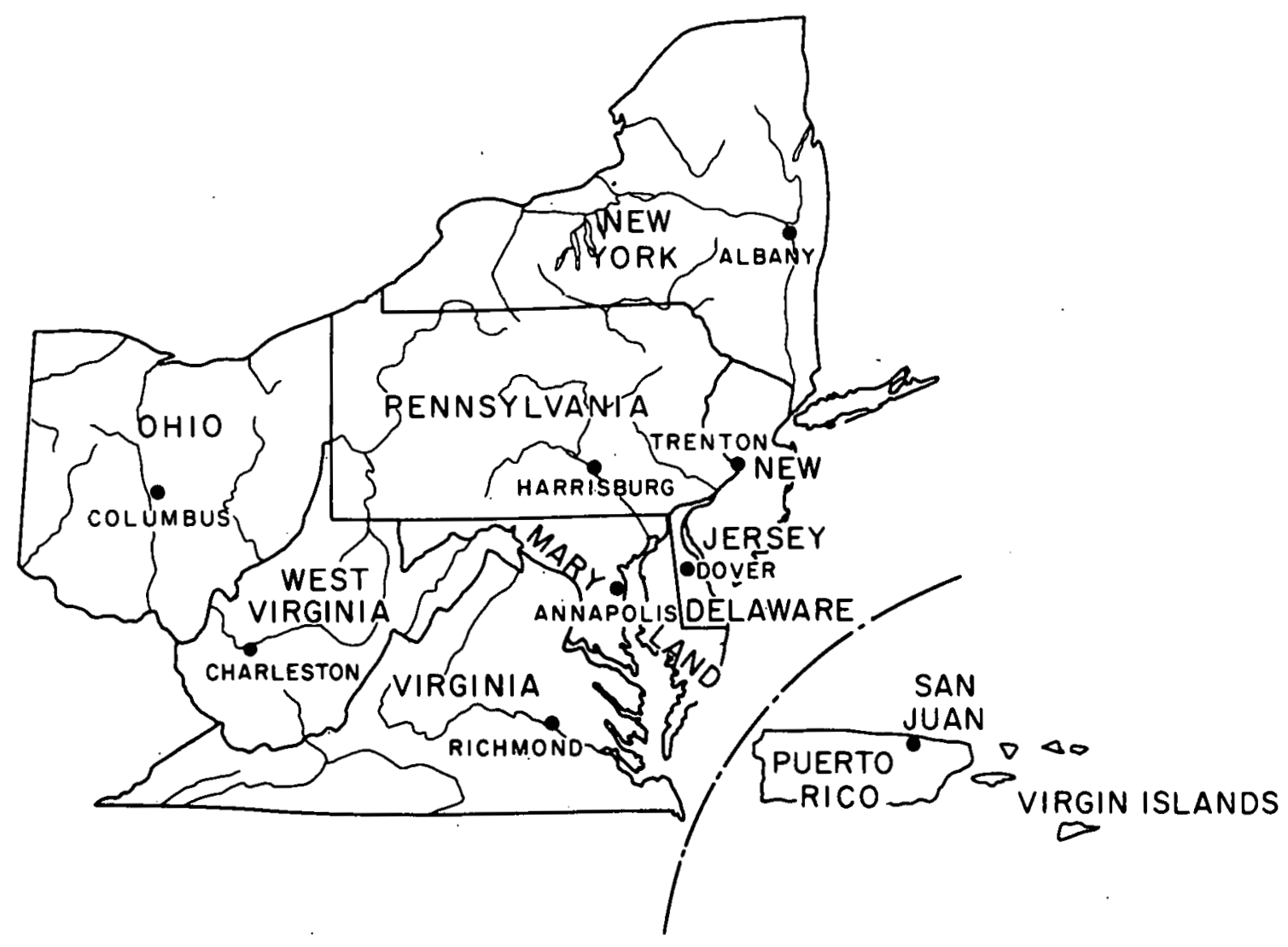




\section{Introduction}

This briefing book is designed to give an overview of the energy situation and of attitudes towards current energy issues in the States of the Middle-Atlantic region, Puerto. Rico and the Virgin Islands.* It was prepared by the Policy Analysis Division of the National Center for Analysis of Energy Systems at Brookhaven National Laboratory in preparation for public meetings that were planned to be held October, 1977 sponsored by the Energy Research and Development Administration on behalf of the new Department of Energy. Although those meetings were not held, the material collected for this report were judged of sufficient interest to warrent its publication in this form.

Many of the central problems of U.S. energy policy are manifested in the region in a magnified form. The region both produces energy resources and consumes imported fuels. It is characterized by highly varied population densities. It economic enterprises run the gamut from agriculture and recreaction to intense industrialization. Environmentally, it has areas of pristine beauty and aesthetic wealth and areas marked by pollution dangerous to the health and welfare of 1ts citizens.

Although the future supply of energy to the region is critically dependent on energy resource polices, for example policies related to coal development, current concerns cluster around policies and technologies that are percelved to have a more direct impact on social welfare. Thus, environmental regulation, energy conservation, utility regulation, the price of energy, and the development of indigenous energy resources are issues of paramount concern and debate.

These issues are discussed in more detall in the body of this report. It should be borne in mind, however, that the energy situation changes rapidly. The current version was revised and updated from a draft completed in April 1977 and, particularly in terms of its representation of reglonal concerns and attitudes, should be used with caution as time progresses from that point.

*The region consists of Ohio, New York, New Jersey, Pennsylvania, Delaware Maryland, Virginia, West Virginia, The District of Columbia, Puerto Rico, and the Virgin Islands. 
CHAPTER II

COMPARISON OF 1975 ENERGY SUPPIY AND DEMAND

\section{Introduction}

A great deal of information is avallable on the energy systems of the states and the District of Columbia, but unfortunately the accuracy of the data and the procedures used to classify them vary greatly. We have attempted to overcome these problems in part by relying on the same source for data on a particular subject for all states and the District of Columbia.

In Chapter III we present a separate description of each of the states, comnonwealths, and the District of Columbia. In this chapter, the states and the District of Columbia are discussed as a group. Those who wish to read about energy supply and demand in Puerto Rico and the Virgin Islands should. turn to Chapter 111.

\section{Energy Demand}

Table 1 shows energy consumption by fuel type. Total electricity sales are shown but not included in the total since the resources used to generate electricity are included.

Table 2 shows the energy consumption by sector. Table 3 shows the percentage distribution of energy consumption across sectors (excluding the utilities)。 Rather substantial differences exist among the states.

Over $60 \%$ of the energy used in both Delaware and West Virginia was used in the industrial sector. As expected, much less was used in this sector in the District of Columbia: approximately $12 \%$ of total energy consumption. There are similarly striking differences among all the sectors.

Tables 4 and 5 show the growth rates for gross energy consumption and for particular fuels. With few exceptions, energy consumption leveled off or declined in the period 1972 to 1975.

Figures 1 through 6 show the trends in total energy consumption and selected fuels since 1960. The U.S. average is shown along with the maximum and minfmum over all the states in the region and the District of Columbia. 
TABLE I

GROSS ENERGY CONSUMPTION ${ }^{1}=1975$

$\left(10^{12}\right.$ Btu $)$

$\begin{array}{lrrrrrrr} & \text { OIL } & \text { NAT. GAS } & \text { COAL } & \text { NUCLEAR } & \text { HYDRO } & \text { TOTAL* } & \text { ELECT } \\ \text { D.C. } & 76.6 & 26.8 & 10.3 & .0 & .0 & 113.7 & 19.7 \\ \text { Delaware } & 305.6 & 19.8 & 24.3 & .0 & .0 & 349.8 & 17.7 \\ \text { Maryland } & 607.5 & 148.4 & 202.4 & 46.1 & 24.0 & 1028.4 & 93.5 \\ \text { New Jersey } & 1577.5 & 253.9 & 58.4 & 33.0 & -2.9 & 1920.0 & 148.3 \\ \text { New York } & 2751.8 & 604.7 & 303.3 & 137.6 & 292.3 & 4089.7 & 325.9 \\ \text { Ohio } & 1301.8 & 996.1 & 1580.0 & .0 & .1 & 3878.0 & 356.6 \\ \text { Pennsylvania } & 1530.4 & 677.0 & 1586.0 & 166.7 & 16.4 & 3976.5 & 300.4 \\ \text { Virginia } & 917.2 & 130.9 & 170.2 & 94.2 & 13.2 & 1325.7 & 132.6 \\ \text { West Virginia } & 244.0 & 162.3 & 831.0 & .0 & 4.9 & 1242.3 & 57.8\end{array}$

TABLE 2

ENERGY CONSUMPTION BY SECTOR ${ }^{1}$ - 1975

$$
\left(10^{12} \mathrm{Btu}\right)
$$

$\begin{array}{lrrrrrrr} & \text { RES. } & \text { COM. } & \text { IND. } & \text { TRAN. } & \text { AGRIC. } & \text { UTILITY } & \text { TOTAI* } \\ \text { D.C. } & 24.6 & 40.9 & 14.9 & 36.9 & .1 & 16.6 & 113.7 \\ \text { Delaware } & 23.6 & 20.1 & 202.8 & 53.4 & 1.5 & 66.1 & 349.8 \\ \text { Maryland } & 161.2 & 98.8 & 283.0 & 292.7 & 5.8 & 280.5 & 1028.4 \\ \text { New Jersey } & 334.7 & 279.3 & 672.5 & 516.1 & 3.5 & 262.2 & 1920.0 \\ \text { New York } & 885.3 & 641.0 & 722.3 & 993.2 & 13.9 & 1159.8 & 4089.7 \\ \text { Ohio } & 651.4 & 313.7 & 1461.6 & 754.8 & 18.3 & 1034.7 & 3878.0 \\ \text { Pennsylvania } & 561.5 & 309.8 & 1515.4 & 757.8 & 20.3 & 1112.1 & 3976.5 \\ \text { Virginia } & 168.7 & 113.1 & 332.7 & 457.5 & 7.2 & 379.1 & 1325.7 \\ \text { West Virginia } & 82.2 & 41.3 & 417.8 & 136.2 & 2.3 & 620.3 & 1242.3\end{array}$

*Electricity consumption omitted from total. Resources used by electric utilities included. 
TABLE 3

ENERGY CONSUMPTION BY SECTOR - $1975^{*}$

(Percent)

$\begin{array}{lrrrrrr} & \text { RES. } & \text { COM. } & \text { IND. } & \text { TRAN. } & \text { AGRIC. } & \text { TOTAL } \\ \text { D.C. } & 21.1 & 35.0 & 12.2 & 31.6 & .1 & 100.0 \\ \text { Delaware } & 7.8 & 6.7 & 67.3 & 17.7 & .5 & 100.0 \\ \text { Maryland } & 19.2 & 11.7 & 33.6 & 34.8 & .7 & 100.0 \\ \text { New Jersey } & 18.5 & 15.5 & 37.2 & 28.6 & .2 & 100.0 \\ \text { New York } & 27.2 & 19.7 & 22.2 & 30.5 & .4 & 100.0 \\ \text { Ohio } & 20.4 & 9.8 & 45.7 & 23.6 & .6 & 100.0 \\ \text { Pennsylvania } & 17.7 & 9.8 & 47.9 & 23.9 & .6 & 100.0 \\ \text { Virginia } & 15.6 & 10.5 & 30.8 & 42.4 & .7 & 100.0 \\ \text { West Virqinia } & 12.1 & 6.1 & 61.5 & 20.0 & .3 & 100.0 \\ & & & & & & \\ \text { United States } & 17.5 & 11.2 & 39.1 & 31.2 & 1.1 & 100.0\end{array}$

*Excludes utility resource use. Includes electricity consumption.

TABLE 4

ANNUAE GROSS ENFRGY CONSUMPTTON GROWTH. RATF ${ }^{l}(\%)$

$\begin{array}{lcc} & \underline{1900-1972} & \frac{1972-1975}{11.0} \\ \text { D.C. } & 3.9 & -11.7 \\ \text { Delaware } & 4.1 & -3.4 \\ \text { Maryland } & 4.2 & -6.9 \\ \text { New Jersey } & 3.6 & -2.8 \\ \text { New York } & 2.9 & -2.0 \\ \text { Ohio } & 3.1 & -2.5 \\ \text { Pennsylvania } & 2.7 & -0.7 \\ \text { Virginia } & 3.4 & -0.9 \\ \text { West Virginia } & 5.9 & -0.7 \\ \text { United States } & 4.6 & \end{array}$


TABLE 5

ANNUAL CONSUMPTION GROWTH RATE BY FUEL TYPE ${ }^{1}$ (1\%)

$\underline{1960-1972 \quad 1972-1975}$

D.C.

Delaware

Maryland

New Jersey

New York

Ohio

Pennsylvania

Virginia

west Virginia

United States
OIL

6.0

2.9

5.5

4. 4

4.7

3.3

3.4

5.9

3.7

4.2

0.7

6.5

1960
6.
8.
7
6
4.
4.
4.
7.
4.

GAS 1972-1975

$-3.7$

$-5.4$

$-7.3$

$-9.3$

$-5.5$

$-5.8$

$-7.9$

$-6.8$

$-.11 .5$

$-4.0$

2.5

$1960-197$
-6.2
2.4
0.2
-12.5
-4.9
2.2
2.5
-3.4
7.1
2.5

COAL

$1972-1975$

$-8.3$

5.8

$-4.8$

20.1

$-4.8$

$-1.5$

$-1.9$

$-8.1$

1.0

0.4

5.2

9.6

*As shown in FEA Strawman data. 

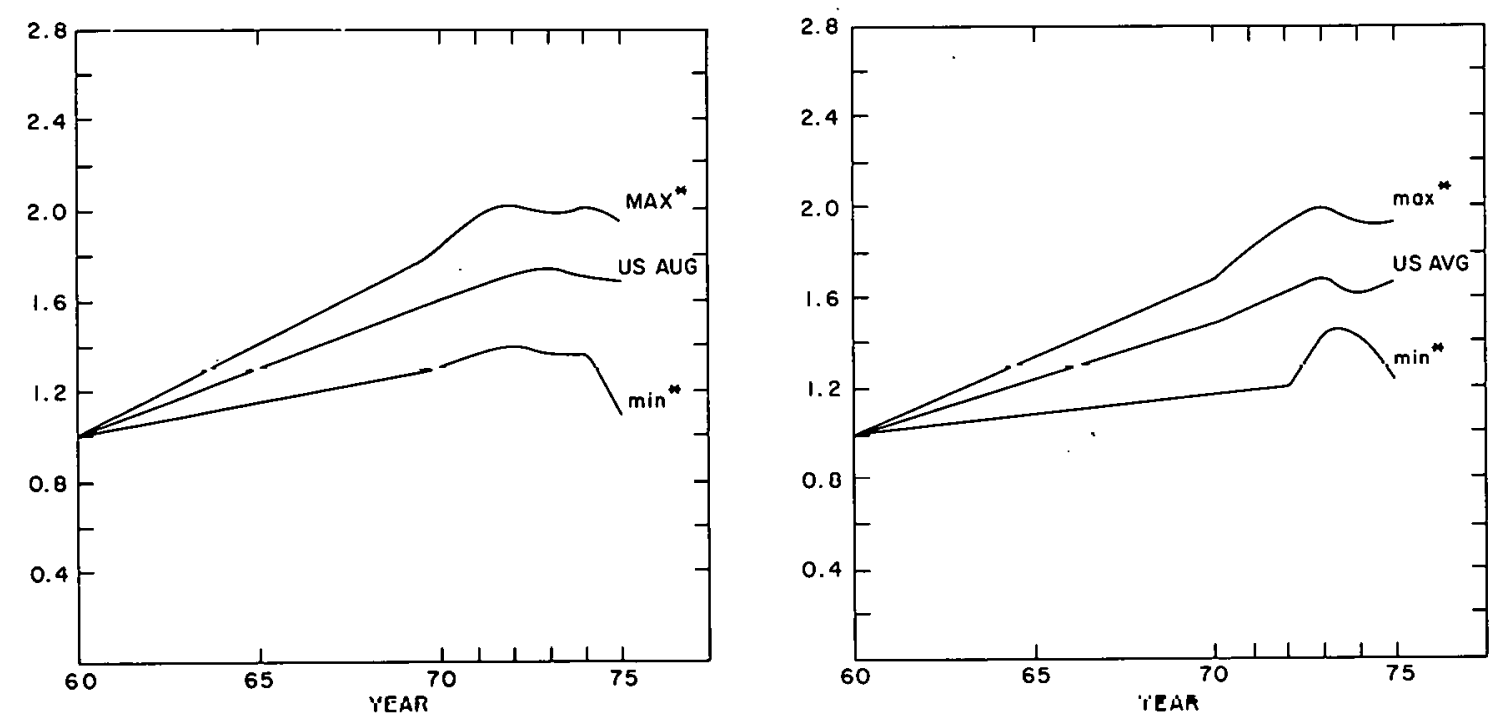

Figure 1. Relative energy use $(1960=1.0)$. Figure 2. Relative gasoline use $(1960=1.0)$.
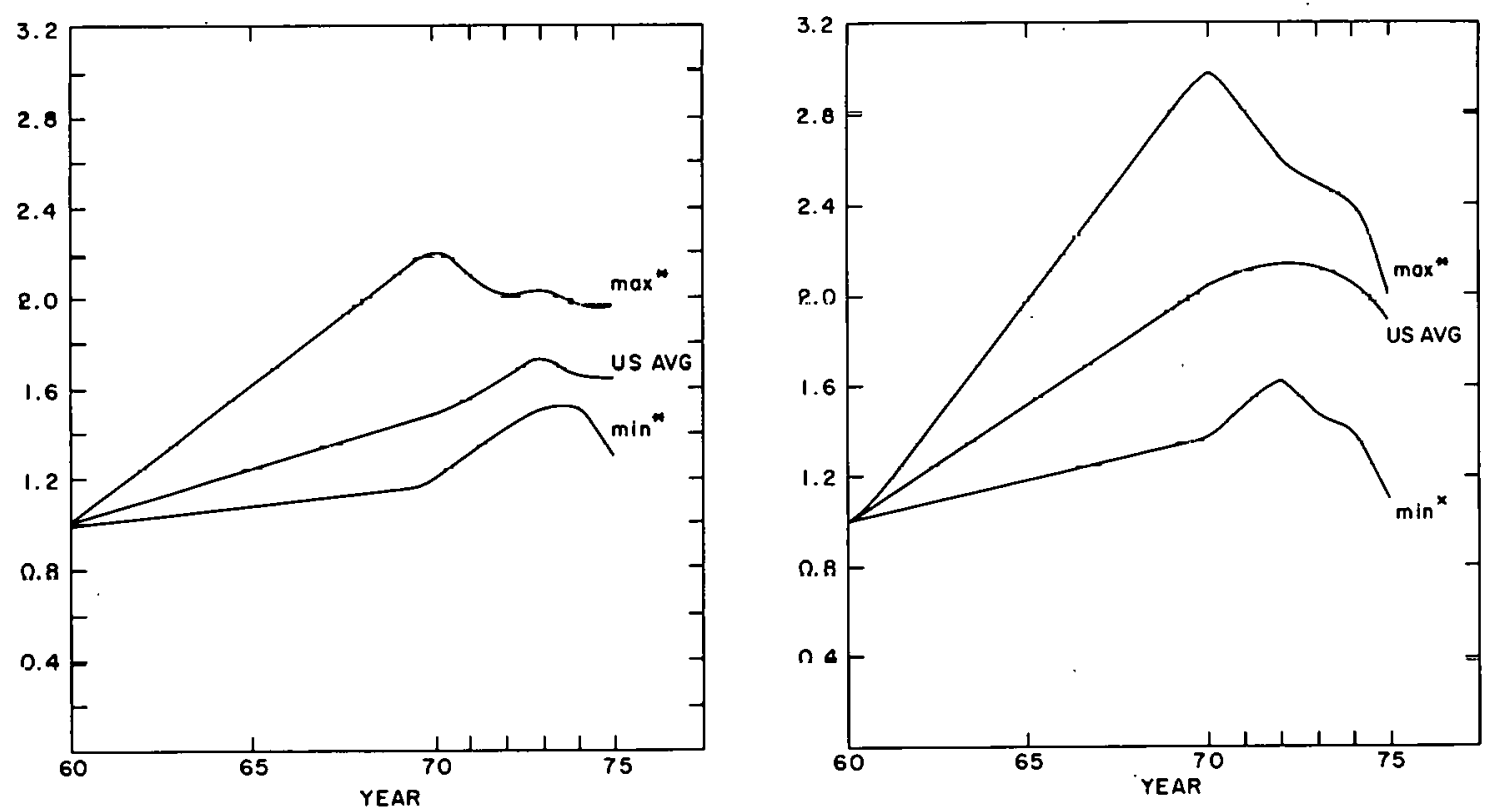

*Maximum and minimum over all the states in the region and the District of Columbia.

Figure 3. Relative ofl use $(1960=1.0)$. Figure 4. Relative natural gas use $(1960=1.0)$. 

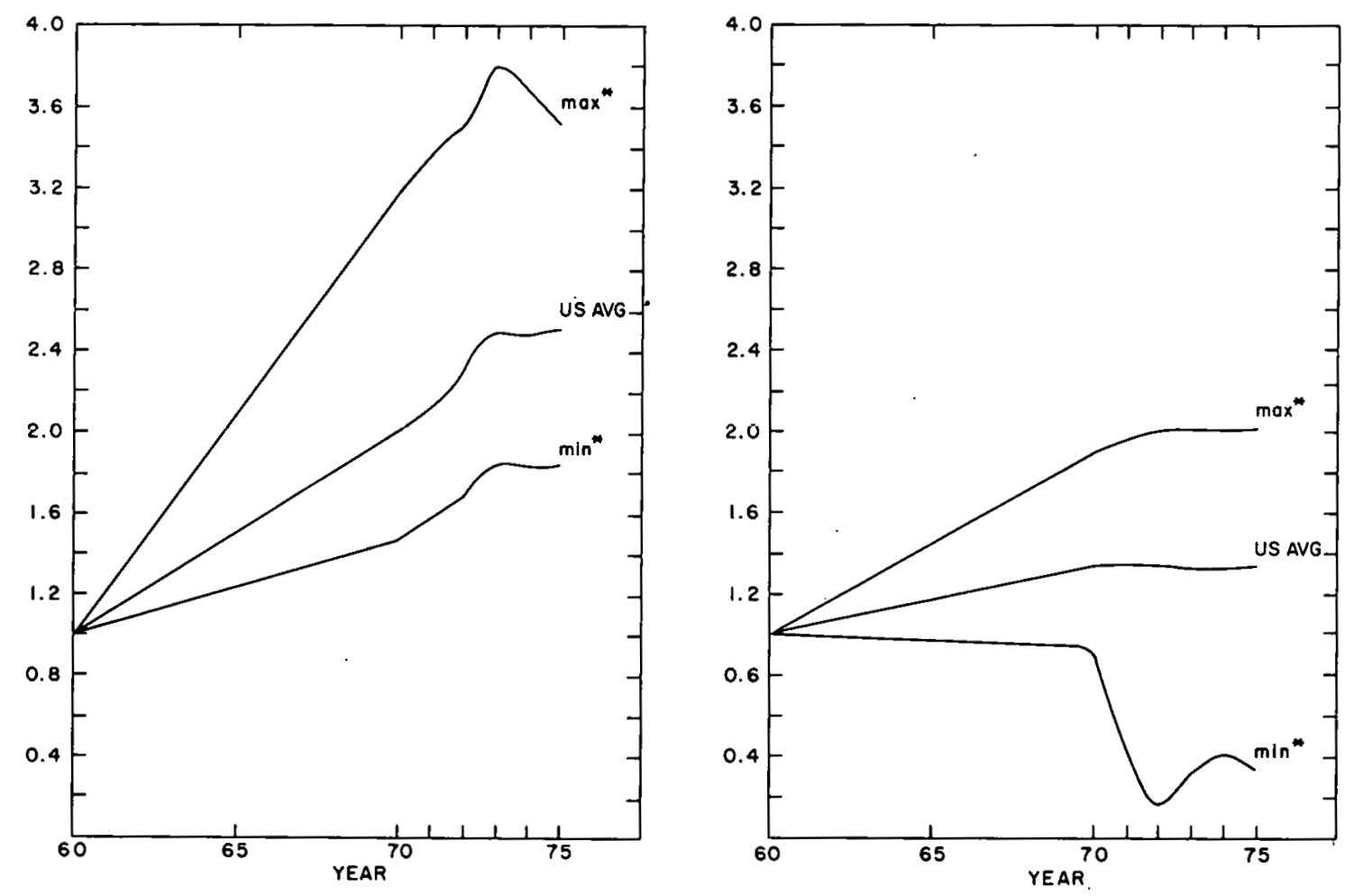

*Maximum and minimum over all the states in the region and the District of Columbia.

F1gure 5. Relative electricity use $(1960=1.0)$. Figure 6 . Relative coal use (1960 1.0$)$. 
Table 6 shows the energy resources used by electric utilities in 1975 and Table 7 shows the percentage mix of fuels used. The very large differences in fuel mix are readily apparent. In Ohio and West Virginia, coal is used almost exclusively. The District of Columbia, Delaware, New Jersey, New York and Virginia are all very dependent on oil. None of the areas dertve a large percentage of its electricity from natural gas.

Some of the states are large importers of electricity, while others are large exporters. For example, New Jersey uses about $87 \%$ more electricity than is generated in the state, while West Virginia exports to other states about $72 \%$ of the electricity generated in the state.

Energy Supply

Table 8 shows the level of energy resource production in 1975 . No state produces more of a resource than it consumes except Virginia, West Virginia, and Pennsylvania. These states produce more coal than they consume. West Virginia produces almost as much natural gas as it consumes. All the areas are dependent on outside supplies for their petroleum.

\section{Prices}

Table 9 shows prices for a few selected fuels. Table 10 shows the ratio of these prices to the average US price for the fuel. 011 prices (to utilities) and gasoline prices do not appear to vary widely on average. Prices for the other fuels do vary. widely. Prlce averages should be used with caution since they hide large variations in prices that may exist within the area over which the data were averaged. For example, in New York in 1975, residential electricity prices varled from about $1.3 \mathrm{c}$ per $\mathrm{kWh}$ to $8.4 \mathrm{c}$ per $\mathrm{kWh}$ for the same type of service. ${ }^{2}$ The state average was $5.1 \mathrm{c}$ per $\mathrm{kWh}$.

\section{Other Data}

Figures 7 and 8 show the average per capita 1ncome and average unemployment rates for 1975. Table 11 shows the ratio of these measures to the U.S, average. While the variations-are striking for the average, it should be remembered that here too the averages hide large varlations that existed within states and tend to mask the very high rates of unemployment that existed for short periods of time during the natural gas shortage. Also 
TABLE 6

ENERGY RESOURCES USED BY ELECTRIC UTILITIES ${ }^{1}$ - 1975.

D.C.

Delaware

Maryland

New Jersey

New York

Ohio

Pennsylvania

Virginia

West Virginia

$$
\left(10^{12} \mathrm{Btu}\right)
$$

OIL

13.9

40.6

113.0

165.9

569.9

23.7

92.8

175.5

4.1

\begin{abstract}
GAS
\end{abstract}
.0

1.8

.5

8.9

14.0

6.3

1.3

.5

.4
COAL

2.7

23.7

96.9

57.3

146.0

1004.6

834.9

95.7

610.9
NUC LEAR

.0

.0

46.1

33.0

137.6

.0

166.7

94.2

.0

$\begin{array}{rr}\text { HYDRO } & \text { TOTAL } \\ .0 & 16.6 \\ .0 & 66.1 \\ 24.0 & 280.5 \\ -2.9 & 262.2 \\ 292.3 & 1159.8 \\ .1 & 1034.7 \\ 16.4 & 1112.1 \\ 13.2 & 379.1 \\ 4.9 & 620.3\end{array}$


TABLE 7

MIX OF RESOURCES USED

BY ELECTRIC UTILITIES \& 1975

(Percent)

$\begin{array}{lrrrrr} & \text { OIL } & \text { GAS } & \text { COAL } & \text { NUCLEAR } & \text { HYDRO } \\ \text { D.C. } & 83.6 & .0 & 16.4 & .0 & .0 \\ \text { Delaware } & 61.5 & 2.7 & 35.8 & .0 & .0 \\ \text { Maryland } & 40.3 & .2 & 34.5 & 16.4 & 8.6 \\ \text { New Jersey } & 63.3 & 3.4 & 21.8 & 12.6 & -1.1 \\ \text { New York } & 49.1 & 1.2 & 12.6 & 11.9 & 25.2 \\ \text { Ohio } & 2.3 & .6 & 97.1 & .0 & .0 \\ \text { Pennsylvania } & 8.3 & .1 & 75.1 & 15.0 & 1.5 \\ \text { Virginia } & 46.3 & .1 & 25.2 & 24.9 & 3.5 \\ \text { West Virginia } & .7 & .1 & 98.5 & .0 & .8 \\ & & & . & & 15.1\end{array}$

TABLE 8

ENERGY RESUURCE FRUUUL'L'LUN ${ }^{3}-19 \% 5$

$\left(10^{12} \mathrm{Btu}\right)$

D. C.

Delaware

Maryland

New Jersey

New York

Ohio

Pennsylvania

Virginia

iJest Virginia

$\begin{array}{rrrr}\text { OIL } & \text { NGL } & \text { GAS } & \text { LUAL } \\ .0 & .00 & .0 & 0 \\ .0 & .00 & .0 & 0 \\ .0 & .00 & .0 & 67 \\ .0 & .00 & .0 & 0 \\ 5.1 & .00 & 6.8 & 0 \\ 55.6 & .00 & 87.9 & 1104 \\ 18.6 & .27 & 86.8 & 2349 \\ .0 & .00 & 6.2 & 966 \\ 14.9 & 23.45 & 151.3 & 2841\end{array}$


TABLE 9

AVERAGE PRICES FOR SELECTED FUELS ${ }^{4}-1975$

$\begin{array}{lccccc} & \begin{array}{c}\text { OIL } \\ \text { UTIIIT } \\ (\$ / \mathrm{Bb} 1)\end{array} & \begin{array}{c}\text { GAS } \\ \text { RESIDENIIAL } \\ \left(\$ / 10^{6} \mathrm{Btu}\right)\end{array} & \begin{array}{c}\text { COAL } \\ \text { UTILITY } \\ (\$ / \text { ton })\end{array} & \begin{array}{c}\text { GASOLINE } \\ (\xi / \text { gallon })\end{array} & \begin{array}{c}\text { ELECTRICITY } \\ \text { RESIDENIAL } \\ (\xi / \text { Kwh })\end{array} \\ \text { D. C. } & 11.76 & 2.40 & 31.77 & 58.50 & 3.95 \\ \text { Delaware } & 11.76 & 2.34 & 31.77 & 56.70 & 4.35 \\ \text { Maryland } & 11.76 & 2.31 & 31.77 & 56.70 & 3.95 \\ \text { New Jersey } & 12.83 & 2.59 & 40.52 & 61.20 & 4.92 \\ \text { New York } & 12.00 & 2.43 & 29.43 & 59.90 & 5.13 \\ \text { Ohio } & 13.77 & 1.51 & 21.65 & 57.20 & 3.41 \\ \text { Pennsylvania } & 13.11 & 1.90 & 22.70 & 53.90 & 4.00 \\ \text { Virginia } & 11.61 & 2.29 & 29.04 & 57.20 & 3.45 \\ \text { West Virginia } & 12.00 & 1.47 & 22.00 & 57.60 & 3.27 \\ \text { United States. } & 12.24 & 1.69 & 18.71 & 57.20 & 3.21\end{array}$

TABLE 10

RATIO OF ENERGY PRICES TO AVERAGE FOR U.S. - :1975

$\begin{array}{ccccc}\text { OIL } & \text { GAS } & \text { COAL } & & \text { EIFCIRICITY } \\ \text { UTILITY } & \text { RESIDENTIAL } & \text { UTILITY } & \text { GASOLINE } & \text { RESIDENIIAL } \\ (\$ / \mathrm{Bbi}) & \left(\$ / 10^{6} \mathrm{Btu}\right) & (\$ / \text { ton }) & (\xi / \text { gallon }) & (\xi / \mathrm{KWh})\end{array}$

$\begin{array}{lrrrrr}\text { D. C. } & .96 & 1.42 & 1.70 & 1.02 & 1.23 \\ \text { Delaware } & .96 & 1.38 & 1.70 & .99 & 1.36 \\ \text { Maryland } & .96 & 1.37 & 1.70 & .99 & 1.23 \\ \text { New Jersey } & 1.05 & 1.53 & 2.17 & 1.07 & 1.53 \\ \text { New York } & .98 & .95 & 1.57 & 1.05 & 1.60 \\ \text { Ohio } & 1.13 & .89 & 1.16 & 1.00 & 1.06 \\ \text { Pennsylvania } & 1.07 & 1.12 & 1.21 & .94 & 1.25 \\ \text { Virginia } & .95 & 1.36 & 1.55 & 1.00 & 1.07 \\ \text { West Virginia } & .98 & .87 & 1.18 & 1.01 & 1.02\end{array}$




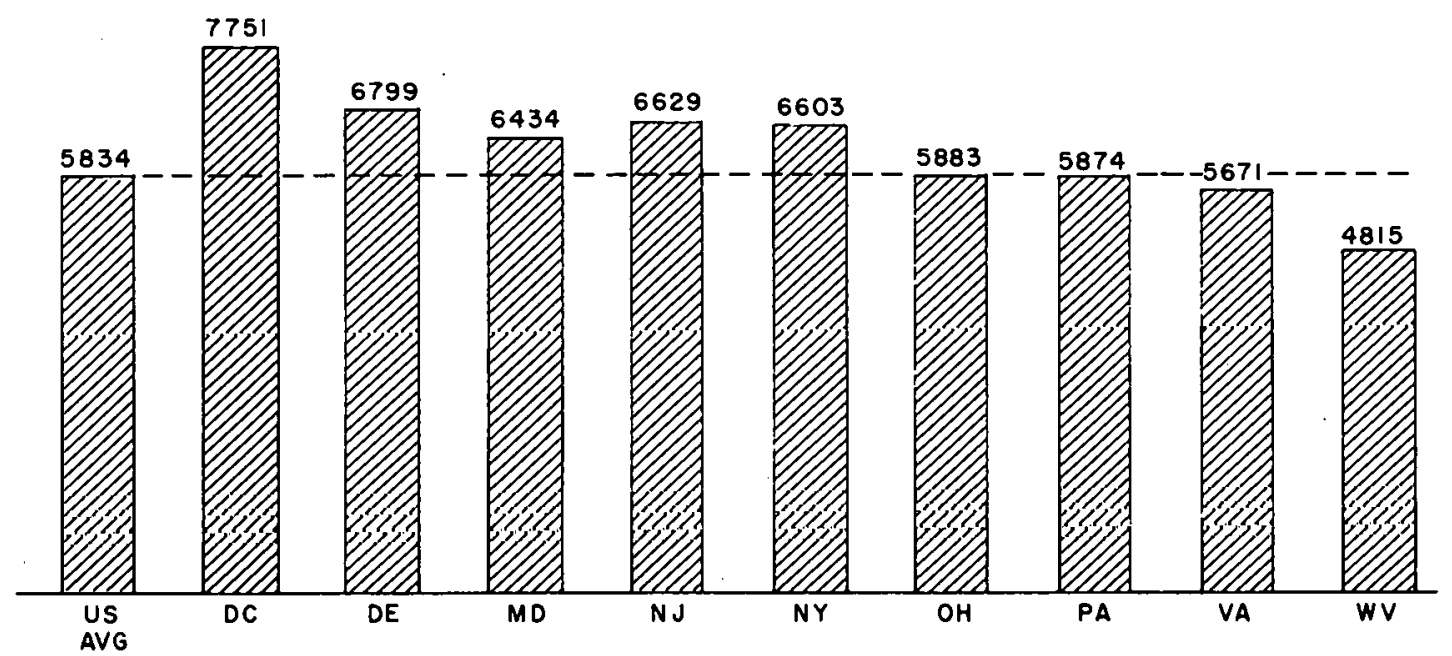

Figure 7. Average per capita income $-1975^{5}$.

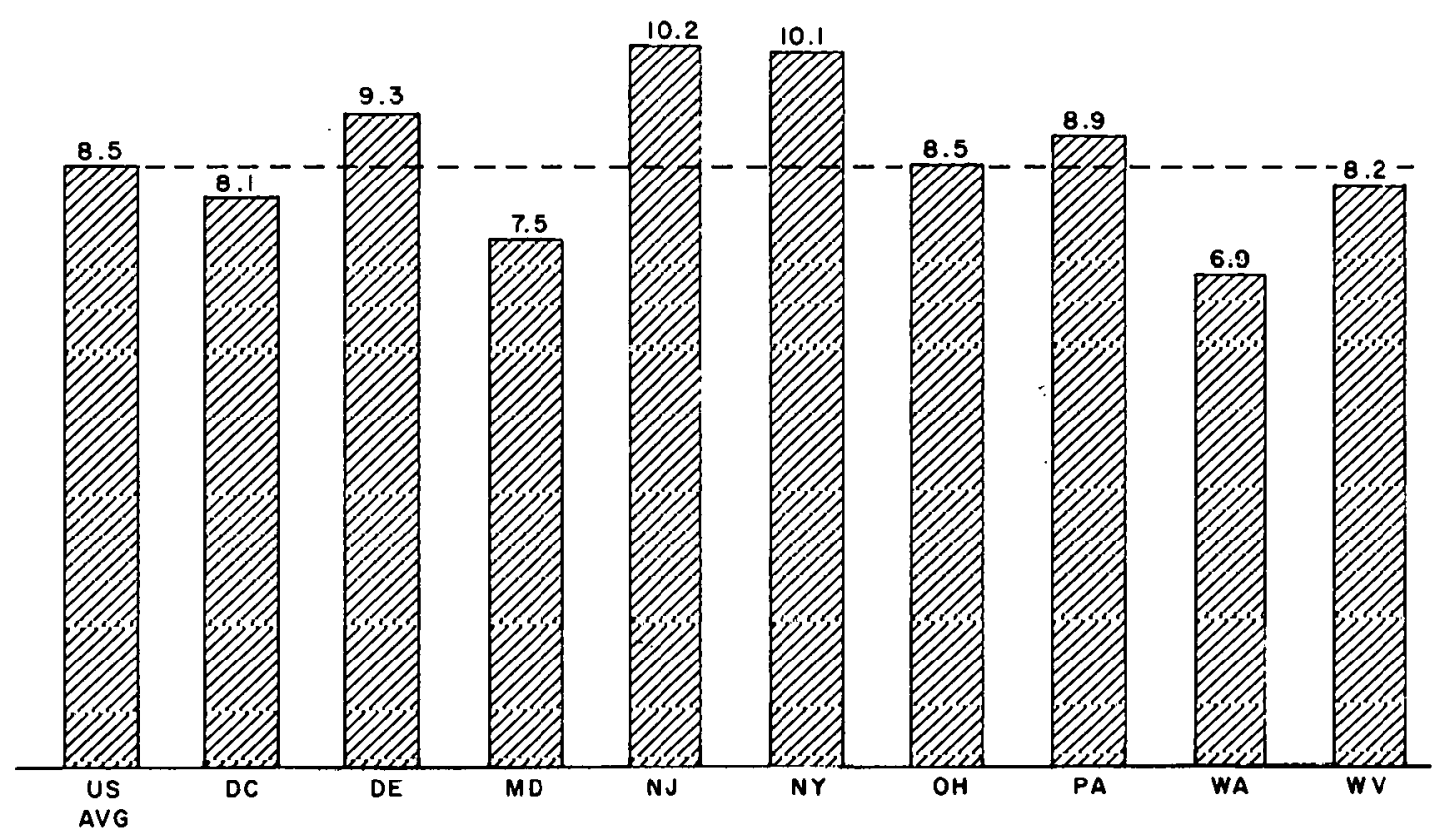

Figure 8. Average unemployment rate - 1975 . 
TABLE 11

RATIO OF PER CAPITA INCOME AND UNEMPLOYMENT RATES TO AVERAGE FOR U.S. - 1975

$\begin{array}{cc}\text { PER CAPITA } & \text { UNEMPLOYMENT } \\ \text { INCOME } & \text { RATE }\end{array}$

$\begin{array}{lrr}\text { D. C. } & 1.33 & .95 \\ \text { Delaware } & 1.17 & 1.09 \\ \text { Maryland } & 1.10 & .88 \\ \text { New Jersey } & 1.14 & 1.20 \\ \text { New York } & 1.13 & 1.19 \\ \text { Ohio } & 1.01 & 1.00 \\ \text { Pennsylvania } & 1.01 & 1.05 \\ \text { Virginia } & .97 & .81 \\ \text { West Virginia } & .83 & .96\end{array}$


hidden are differences in income levels and unemployment rates that exist between sexes, races, and skill groups.

Climatic conditions can have a significant impact on energy consumption levels. The winter of 1976-77 was colder than normal throughout the Northeast and Mid-Atlantic regions. The impact was far from uniform however. Heating degree days in the District of Columbia were about $12 \%$ above normal through March of this past winter, but in Cincinnati, they were more than $30 \%$ above normal. The change this winter over last is particularly striking. Many areas experienced increases in heating degree days this winter over last of more than $40 \%$. cold winter should not be used as a scapegoat for the energy shortages that occurred last winter, however. Equally at fault are residencies, commercial establishments, and industries that are inadequately insulated and use inefficient heating equipment, processes, and operating procedures. This situation is in part a result of energy prices that have been kept low by government regulation. Supply problems were aggravated by outdated and cumbersome federal regulations, and miscalculations on the part of some utilities concerning appropriate storage levels for natural gas. 
CHAPTER III

ENERGY SUPPLY AND DEMAND

$\underline{\text { Introduction }}$

In this chapter we present basic energy supply, demand and price data for the states of Delaware, Maryland, New Jersey, New York, Ohio, Pennsylvania, Virginia, and West Virginia, the District of Columbia, and the Commonwealths of Puerto Rico and the Virgin Islands. Selected economic, demographic, and climatic characteristics are also presented. At the end of this chapter, tables similar to those presented for the states and the District of Columbia are given so that comparisons with national averages can be made.

Information on the energy systems of Puerto Rico and the Virgin Islands is presented in a different format than used for the other areas being described because 1) the energy systems of Puerto Rico and the Virgin Islands differ radically from those of the states and the District of Columbia, and 2) information on the commonwealths was not available on a basis consistent with the data for the states and the District of Columbia.

District of Columbia (D.C.)

Energy. Demand

When examining the energy statistics that are presented below for the District of Columbia, it should be remembered that large numbers of persons live in Virginia and Maryland and commute to and from the District. Because of this, the energy system of the District is intimately tied to activities in the netghboring states.

Gross energy demand grew at an average rate of $6.3 \%$ per year from 1960 to $1970 .^{1}$ From 1970 to 1975 energy consumption decreased at about $9 \%$ per year. The rate of decline from 1972 to 1975 was particularly dramatic: $11 \%$ per year.

Energy consumption data for the major sectors, including estimates of feedstocks, are shown in Table 12. Electricity demand is omtted from the 
TABLE 12

D.C. ENERGY CONSUMPTION IN $1975^{1}$

$$
\left(10^{12} \mathrm{Btu}\right)
$$

$\begin{array}{lrrrrrrr}\text { FUEL } & \text { RES. } & \text { COM. } & \text { IND. } & \text { TRAN. } & \text { AGRIC. } & \text { UTIIITY } & \text { TOTAL } \\ \text { ELECTRICITY } & 3.2 & 11.7 & 4.7 & .1 & .0 & .0 & 19.7 \\ \text { PETROLEUM } & 7.6 & 16.7 & 1.5 & 36.8 & .1 & 13.9 & 76.6 \\ \text { NAT. CAS } & 13.6 & 12.4 & .8 & .0 & .0 & .0 & 26.8 \\ \text { COAL } & .2 & .1 & 7.2 & .0 & .0 & 2.7 & 10.3 \\ \text { NUCLEAR } & .0 & .0 & .0 & .0 & .0 & .0 & .0 \\ \text { HYDRO } & .0 & .0 & .0 & .0 & .0 & .0 & .0 \\ \text { TOTAL } & 24.6 & 40.9 & 14.2 & 36.9 & .1 & 16.6 & 113.7 * \\ \text { PER CAP. (10. }{ }^{6} \text { BtuL } & 34.3 & 57.1 & 19.9 & 51.5 & .1 & 23.2 & 158.7\end{array}$

TABLE 13

DISTRIBUTION OF ENERGY CONSUMPIION FOR D.C.

(PERCENT)

$\begin{array}{lrrrrrrr}\text { FUEL } & \text { RES. } & \text { COM. } & \text { IND. } & \text { TRAN. } & \text { AGRIC. } & \text { UTILITYY } & \text { IOIAL* } \\ \text { ELECTRICITY } & 13.0 & 28.6 & 33.0 & .3 & .0 & .0 & .0 \\ \text { PETROLEUM } & 30.9 & 40.8 & 10.6 & 99.7 & 100.0 & 83.6 & 67.6 \\ \text { NAT. GAS } & 55.3 & 30.3 & 5.6 & .0 & .0 & .0 & 23.6 \\ \text { COAL } & .8 & .3 & 50.8 & .0 & .0 & 16.4 & 9.0 \\ \text { NUCLEAR } & .0 & .0 & . .0 & .0 & .0 & .0 & .0 \\ \text { HYDRO } & .0 & .0 & .0 & .0 & .0 & .0 & .0 \\ \text { TOTAL } & 100.0 & 100.0 & 100.0 & 100.0 & 100.0 & 100.0 & 100.0\end{array}$

*Electricity omitted to avoid double counting. 
total entry to avoid double counting (resources used to generate electricity are included).

The distribution of fuels used in each sector, and for all sectors combined, is shown in Table 13. Electricity consumption was excluded from the total column when this distribution was calculated. Compared with the U.S. (shown in Table 71), D.C. is much more reliant on petroleum, but uses, on a percentage basis, much less coal.

Demand for electricity grew at 8.5\% per year from 1960 to 1970 and at $1.4 \%$ from 1970 to 1975 .

The mix of fuels used by the electric utilities is shown in Table 14 .

TABLE 14

PERCENTAGE MIX OF FUELS USED BY ELECTRIC UTILITIES

OIL GAS COAL NUCLEAR HYDRO

1960

2.6

$.0 \quad 97.4$

.0

.0

1970

59.0

$.0 \quad 41.0$

.0

.0

1975

83.6

$.0 \quad 16.4$

.0

.0

The shift to oil away from coal is dramatic. This shift, prior to 1973, was partially a response to changing relative prices of coal and oil. In more recent years environmental factors have been an influence.

Energy Supply

There is no significant production of energy resources in D.C.

$\underline{\text { Prices }}$

Prices for selected energy products are shown in Table 15. The large increase in oil prices in general, and for utilities in particular, is clear. 
TABLE 15

A COMPARISON OF AVERAGE PRICES PAID FOR

SELECTED ENERGY PRODUCTS 4

D.C.

Fuel

1972

$i 975$

Percent Increase

oil

Residential - Retail

( $\$ / 100$ gallons)

19.78

42.48

$115 \%$

Utility (AVG for $\mathrm{MD}, \mathrm{DC}, \& \mathrm{DE}$ )

$(\$ / B b 1)$

$3.69 \quad 11.76$

$219 \%$

Gas

Residential
$\left(\$ / 10^{6} \mathrm{Btu}\right)$
1.55
2.40
$55 \%$

Commercial

$\left(\mathrm{S} / 10^{6} \mathrm{Btu}\right)$

1.19

2.00

$68 \%$

Industrial

$\left(\$ / 10^{6} \mathrm{Btu}\right)$

.95

1.49

$57 \%$

Utility (AVG for $M D, D C, \& D E$ )

( $/$ Mcf)

47.1

90.7

$1 / 1 \%$

Coal - Ut1lity (AVG for $M D, D C, \& D E$ )
(\$/ton)
13.46
31.77
$136 \%$

Gasoline - Regular inc. tax

(c/gallon)

$37.65 \quad 58.48$

$55 \%$

Electricity

Total Utility Fossil Fuel Costs

(c/Kivin) (AVG for MD, DC, \& DE).6 $1.74 \quad 190 \%$

Resj.dential

$$
(c / \mathrm{kwh})
$$

2.62

3.95

$51 \%$

Comnercial and Industriai

$$
\begin{gathered}
\text { Sinall ( } c / \text { Kwh) } \\
\text { Large ( } c / \text { Kwh) } \\
\text { Total Sales } \\
\text { ( } c / \text { Kwh) }
\end{gathered}
$$

2.44

3.85

$58 \%$

Large $(c /$ Kwh)

1.42

2.67

$88 \%$

2.12

3.49

$65 \%$

Consumer Price Index $(1967=100)$ 
As seen in Tables 12 and 13 , the residential and commercial sectors rely heavily on natural gas. Price increases of natural gas used in these sectors were larger than the national average (see Table 73). In 1975, residential gas prices in D.C. were $42 \%$ higher than the U.S. average.

\section{Other Data}

General economic, demographic, and climatic characteristics are shown in Table 16. Per capita income was about 33\% higher than the U.S. average in 1975. The unemployment rate was close to the national average. Heating degree days in D.C. were $12 \%$ above normal through March of the winter of 1976-1977. For those who were lulled into a false sense of contentment by the relatively warm winters of 1974-1975 and 19.75-1976, the change in 1976-1977 was particularly jarring. Heating degree days through March of 1976-1977 were almost $40 \%$ above the previous year. 
GENERAL ECONOMIC AND DEMOGRAPHIC CHARACTERISTICS

$$
\text { D.C. IN } 1975^{6}
$$

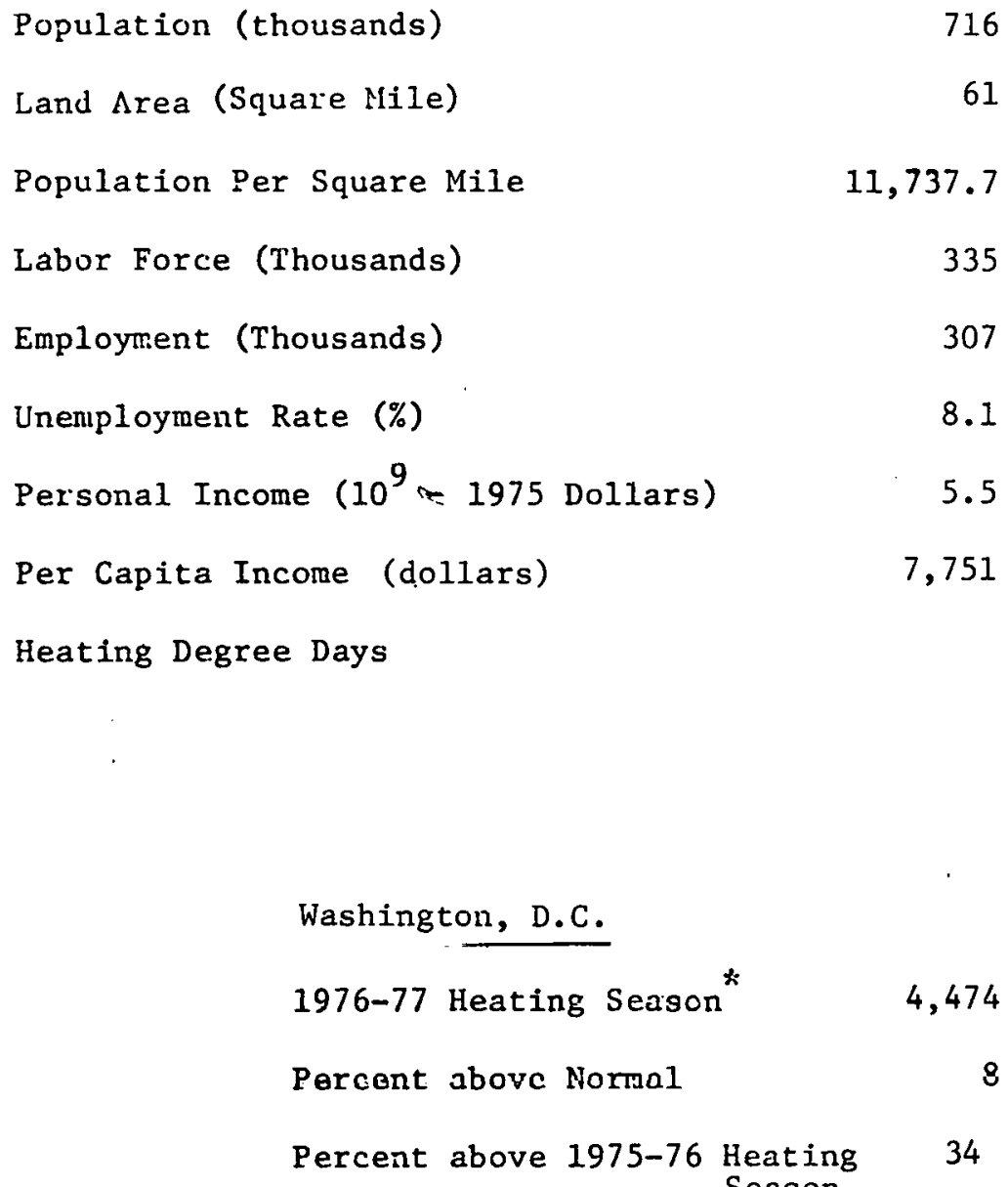

*Accumulation from July 1 to May 1 . 
Delaware

\section{Energy Demand}

Gross energy demand grew at an average rate of $4.4 \%$ per year from 1960 to 1970. From 1970 to 1975 growth averaged 2.2\%.

Energy Consumption data for the major sectors are shown in Table 17. Feedstock estimates are included. Electricity demand is omitted from the grand total entry to avoid double counting since resources used to generate electricity are included.

The percentage of total consumption in each sector met by a particular fuel is shown in Table 18. When the percentages were calculated for the total column, electricity consumption was excluded since resources used to generate the electricity were included.

All sectors rely very heavily on petroleum. Over $87 \%$ of the energy used in Delaware comes from petroleum compared with about $46 \%$ for the U.S. The relatively high energy consumption in the industrial s̃ector, as indicated by the high per capita consumption shown in Table 17 for that sector, is partially a result of the large volume of energy intensive products produced in Delaware for use outside the state.

Demand for electricity grew at a 12.3\% per year from 1960 to 1970. Th1s high growth rate dropped to $2.2 \%$ per year over the period 1970 to 1975 . The mix of fuels used by the electric utilities is shown in Table 19.

\section{TABLE 17}

PERCENTAGE MIX OF FUELS USED BY ELECTRIC UTILITIES

OIL GAS COAL NUCLEAR HYDRO

1960

1.1

18.3

80.6

.0

.0

1970

26.4

9.0

64.6

.0

.0

1975

61.5

2.7

35.8

.0

.0 
TABLE 18

DELAWARE ENERGY CONSUMPTION IN $1975^{1}$

$$
\left(10^{12}\right. \text { Btu) }
$$

\begin{tabular}{lrrrrrrr} 
FUEL & RES. & COM. & \multicolumn{1}{c}{ IND. } & TRAN. & AGRIC. & UTILITY & TUTAL \\
ELECTRICITY & 5.1 & 4.1 & 8.5 & .0 & .0 & .0 & 17.7 \\
PETROLEUM & 11.3 & 12.9 & 185.9 & 53.4 & 1.5 & 40.6 & 305.6 \\
NAT. GAS & 7.2 & 3.1 & 7.7 & .0 & .0 & 1.8 & 19.8 \\
COAL & .0 & .0 & .6 & .0 & .0 & 23.7 & 24.3 \\
NUCLEAR & .0 & .0 & .0 & .0 & .0 & .0 & .0 \\
$\begin{array}{l}\text { HYDRO } \\
\text { TOTAL }\end{array}$ & .0 & .0 & .0 & .0 & .0 & .0 & .0 \\
& 23.6 & 20.1 & 202.8 & 53.4 & 1.5 & 66.1 & 349.8 * \\
PER CAP. $\left(10^{6} \mathrm{Btu}\right)$ & 40.8 & 31.7 & 350.2 & 92.2 & 2.6 & 114.1 & 604.1
\end{tabular}

TABLE 19

DISTRIBUTION OF ENERGY CONSUMPTION FOR DFI.AWARF,

(PERCENT)

$\begin{array}{lrrrrrrr}\text { HUEL } & \text { RES. } & \text { COM. } & \text { IND. } & \text { TRAN. } & \text { AGRIC. } & \text { UTTITTY } & \text { TYTAL * } \\ \text { ELECTRICITY } & 21.6 & 20.4 & 4.2 & .0 & .0 & .0 & .0 \\ \text { PETROLEUM } & 47.9 & 64.2 & 91.7 & 100.0 & 100.0 & 61.5 & 87.4 \\ \text { NAT. GAS } & 30.5 & 15.4 & 3.8 & .0 & .0 & 2.7 & 5.7 \\ \text { COAL } & .0 & .0 & .3 & .0 & .0 & 35.8 & 7.0 \\ \text { NUCLEAR } & .0 & .0 & .0 & .0 & .0 & .0 & .0 \\ \text { HYDRO } & .0 & .0 & .0 & .0 & .0 & .0 & .0 \\ \text { TOTAL } & 100.0 & 100.0 & 100.0 & 100.0 & 100.0 & 100.0 & 100.0\end{array}$

*Electricity omitted to avoid double counting. 
Energy Supply

There is no significant production of energy resources in Delaware. Prices

Prices for selected fuels are shown in Table 20.

Since prices in Delaware were not always read1ly avallable for all the fuels listed, prices shown in Table 20 are sometimes for nelghboring areas and are marked as such.

Electricity prices increased more than the national average. In 1975 the average cost of a kwh in the Delaware, Maryland and D.C. area, was $33 \%$ more than the U.S. average. This is partially due to the heavy reliance of the electric utilities in this area on oil and the very large increase in the cost of oil to utilities.

\section{Other Data}

General economic, demographic, and climatic characteristics are shown in Table 21. Per cap1ta income in Delaware in 1975 was about 17\% above the national average, however the unemployment rate was about $10 \%$ above the national average $(9.3 \%$ vs $8.5 \%)$. 
TABLE 20

A COMPARISON OF AVERAGE PRICES PAID FOR

SELECTED ENERGY PRODUCTS ${ }^{4}$

DELAWARE

Fuel

1972

1975

Percent Increase

Oil

Residential - Retail (For Baltimore)
(3/100 gullons)
19.3'
41.06
$112 \%$

Utility (AVG for $M D, D E, \& D C$ )

$$
(\$ / \mathrm{Bb} I)
$$

3.69

11.76

$219 \%$

Gas

Residential

$$
\left(\$ / 10^{6} \mathrm{Btu}\right)
$$

1.65

2.34

$42 \%$

Commercial

$\left(\mathrm{S} / 10^{6} \mathrm{Btu}\right)$

1.26

1.88

$49 \%$

Industrial

$\left(\$ / 10^{6} \mathrm{Btu}\right)$

.62

1.20

$94 \%$

Utility (AVG for $M D, D E, \& D C$ )

$$
(\epsilon / \mathrm{McF})
$$

47.1

90.7

$141 \%$

Coal - Utility (AVG for MD, DE, \& DC)

$$
(\$ / \text { ton })
$$

13.46

31.77

$136 \%$

Gasoline - Regular

$$
\text { (c/gallon) }
$$

38.06

56.68

$49 \%$

Electricity

Total Utility Fossil Fuel Costs

$$
\text { (c/Kwh) (AVG for } M D, D E, D C \text { ) } .6
$$

1.74

$190 \%$

\section{Residential}

$$
\text { (c/Kwh). }
$$

3.04

4.35

$43 \%$

Commercial and Industrfal

Smal1 (c/Kwh)

2.55

4.0

$57 \%$

Large ( $c / K w h)$

1.51

2.93

$94 \%$

Total Sales

(c/Kwh)

2.13

3.59

$69 \%$ 
TABLE 21

GENERAL ECONOHIC AND DEMOGRAPHIC CHARACTERISTICS

$$
\text { OF DELAWARE IN } 1975^{6}
$$

Population (thousands)

Land Area (Square Mile)

1,982

Population Per Square Mile

292.1

Labor Force (Thousands)

Employment (Thousands)

Unemployment Rate (\%)

9.3

Personal Income $\left(10^{9}-1975\right.$ Dollars $)$

3.9

Per Capita Income (1975 Dollars)

6,799

Heating Degree Days

Wilmington

1976-77 Heating Seascn ${ }^{*} \quad 5,316$

Percent above Normal

10

Percent above 1975-76 Heating

25

Season

*Accumulation from July 1 to My 1 . 


\section{Maryland}

Energy Demand

Gross energy demand grew at an average rate of $4.5 \%$ from 1960 to 1970. From 1970 to 1975 energy consumption declines by slightly more than $1 \%$ per year.

Energy consumption data, which includes estimates of fuels used for feedstocks, are shown in Table 22 for all the major sectors. Electricity demand is omfred from the grand total entry to avoid double counting since resources used to generate electricity are included.

TABLE 22

MARYLAND ENERGY CONSUMPTION IN $1.975^{1}$

$$
\left(10^{12}\right. \text { Btu) }
$$

\begin{tabular}{|c|c|c|c|c|c|c|c|}
\hline FUEL & RES. & COM. & IND. & TRAN. & AGRIC. & UTILITY & TOTAL \\
\hline ELECTRICITY & 32.7 & 25.4 & 34.8 & .6 & .0 & .0 & 93.5 \\
\hline PETROLEUM & 56.8 & 46.9 & 95.1 & 289.9 & 5.8 & 113.0 & 607.5 \\
\hline NAT. GAS & 71.4 & 26.4 & 47.9 & 2.2 & .0 & .5 & 148.4 \\
\hline COAL & .3 & .1 & 105.1 & .0 & .0 & 96.9 & 202.4 \\
\hline NUCLEAR & .0 & .0 & .0 & .0 & .0 & 46.1 & 46.1 \\
\hline HYDRO & .0 & .0 & .0 & .0 & .0 & 24.0 & 24.0 \\
\hline TOTAL & 161.2 & 98.8 & 283.0 & 292.7 & 5.8 & 280.5 & $1028.4 *$ \\
\hline PER CAP. $\left(10^{6}\right.$ Btu $)$ & 39.3 & 24.1 & 69.0 & 71.4 & 1.4 & 68.4 & 251.0 \\
\hline
\end{tabular}

*Electricity omitted to avoid double counting.

The percentage of total consumption in each sector met by a particular fuel is shown in Table 23. Energy from coal supplies are approximately the same percentage of total energy demand in Maryland as in the U.S. 0il supplies about $14 \%$ more of the energy demand in Maryland than 1s typical for the nation as a whole. 
Demand for electricity grew at 9.6\% per year from 1960 to 1970 and $4.1 \%$ from 1970 to 1975 .

The mix of fuels used by the electric utilities is shown in Table $24^{\circ}$. Note the rapid growth in the use of nuclear power.

TABLE 23

\section{DISTRIBUTION OF ENERGY CONSUMPTION FOR MARYLAND}

(PERCENT)

$\begin{array}{lrrrrrrr}\text { FUEL } & \text { RES. } & \text { COM. } & \text { IND. } & \text { TRAN. } & \text { AGRIC. } & \text { UTIIITY } & \text { TOTAL * } \\ \text { ELECTRICITY } & 20.3 & 25.7 & 12.3 & .2 & .0 & .0 & .0 \\ \text { PETROLEUM } & 35.2 & 47.4 & 33.6 & 99.0 & 100.0 & 40.3 & 59.1 \\ \text { NAT. GAS } & 44.3 & 26.7 & 16.9 & .8 & .0 & .2 & 14.4 \\ \text { COAL } & .2 & .1 & 37.2 & .0 & .0 & 34.5 & 19.7 \\ \text { NUCLEAR } & .0 & .0 & .0 & .0 & .0 & 16.4 & 4.5 \\ \text { HYDRO } & .0 & .0 & .0 & .0 & .0 & 8.6 & 2.3 \\ \text { TOTAL } & 100.0 & 100.0 & 100.0 & 100.0 & 100.0 & 100.0 & 100.0\end{array}$

*Electricity omitted to avoid double counting.

TABLE 24

PERCENTAGE MIX OF FUELS USED BY ELECTRIC UTILITIES ${ }^{1}$

$\begin{array}{rrrrrr} & \text { OIL } & \text { GAS } & \text { COAL } & \text { NUCLEAR } & \text { HYDRO } \\ 1960 & 2.8 & .1 & 83.2 & .0 & 13.8 \\ 1970 & 26.6 & 4.4 & 61.4 & .0 & 7.5 \\ 1975 & 40.3 & .2 & 34.5 & 16.4 & 8.6\end{array}$

While coal was used for a much smaller percentage of generation in 1975 than 1960, the actual amount of coal used in 1975 was about 14\% greater than in 1960 . 


\section{Energy. Supply}

There is no significant production of oil, natural gas liquids, or natural gas in Maryland. However in 1975 approximately $67 \times 10^{12}$ Btu of coal were mined. The reserve/production ratio in 1975 was approximately 400 . About $65 \%$ of the coal is estimated to have a sulfur content of $1 \%-3 \%$.

\section{Prices}

Prices for selected fuels are shown in Table 25.

Other Data

General economic, demographic, and climatic characteristics are shown in Table 26. Per capita income was about $10 \%$ above the national average in Maryland in 1975. The unemployment rate was about 7.5 compared to the national average of $8.5 \%$. 
TABLE 25

A COMPARISON OF AVERAGE PRICES PAID FOR

SELECTED ENERGY TRONICTS ${ }^{4}$

MARYLAND

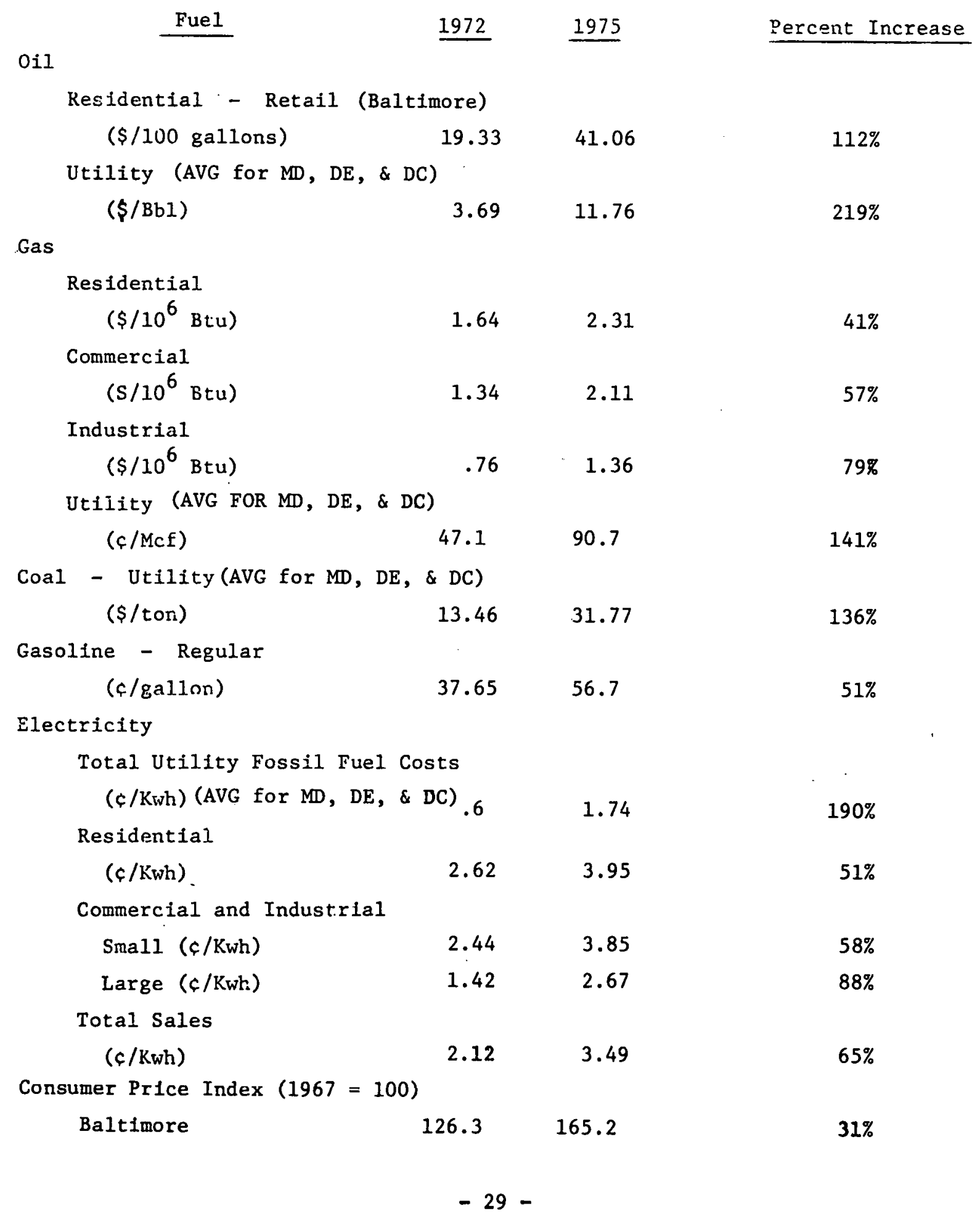


TABLE 26

GENERAL ECONOMIC AND DEMOGRAPHIC CHARACTERISTICS

$$
\text { OF MARYLAND IN } 1975^{6}
$$

$\begin{array}{lr}\text { Population (thousands) } & 4,098 \\ \text { Land Area (Square Mile) } & 9,891 \\ \text { Population Yer Square Mile } & 414.3 \\ \text { Labor Force (Thousands) } & 1,833 \\ \text { Employment (Thousands) } & 1,696 \\ \text { Unemployment Rate (\%) } & 26.4 \\ \text { Personal Income (10 }{ }^{9} \text { - } 1975 \text { Dollars) } & 6,434 \\ \text { Per Capita Income (1975 Dollars) } & \\ \text { Heating Degree Days } & \end{array}$

Baltimore

1976-77 Heating Season ${ }^{*} \quad 5,025$

Percent above Normal 9

Percent above 1975-76 Heating 28

*Accumulation from July 1 to May 1. 
New Jersey

Energy Demand

Gross energy demand grew at an average rate of $4.2 \%$ per year from 1960 to 1970. From 1970 to 1975 however, energy consumption decreased at about $4.1 \%$ per year.

Energy consumption data, which include estimates of fuels used for feedstocks, are shown in Table 27. Electricity consumption is omitted from the grand total to avold double counting since resources used to generate electricity are included.

The percentage of the total consumption in each sector that is met by a particular fuel is shown in Table 28. While all sectors are large users of petroleum, the industrial and transportation sectors account for about $68 \%$ of all petroleum use in the state. Over $82 \%$ of the energy used in New Jersey comes from petroleum compared with about $46 \%$ for the U.S.

Demand for electricity grew at a 8\% per year from 1960 to 1970 and about $2.7 \%$ per year from 1970 to 1975 . The $\mathrm{mix}$ of fuels used by electric utilities is shown in Table 29.

TABLE 27

NEW JERSEY ENERGY CONSUMPTION IN $1975^{1}$

$\left(10^{12} \mathrm{Btu}\right)$

$\begin{array}{lrrrrrrr}\text { FUEL } & \text { RES. } & \text { COM. } & \text { IND. } & \text { TRAN. } & \text { AGRIC. } & \text { UTILITY } & \text { TOTAL } \\ \text { ELECTRICITY } & 49.7 & 47.7 & 50.9 & .0 & .0 & .0 & 148.3 \\ \text { PETROLEUM } & 151.5 & 176.5 & 564.4 & 515.7 & 3.5 & 165.9 & 1577.5 \\ \text { NAT, GAS } & 133.5 & 55.1 & 56.0 & .4 & .0 & 8.9 & 253.9 \\ \text { COAL } & .0 & .0 & 1.1 & .0 & .0 & 57.3 & 58.4 \\ \text { NUCLEAR } & .0 & .0 & .0 & .0 & .0 & 33.0 & 33.0 \\ \text { HYDRO } & .0 & .0 & .0 & .0 & .0 & -2.9 & -2.9 \\ \text { TOTAL } & 334.7 & 279.3 & 672.5 & 516.1 & 3.5 & 262.2 & 1920.0 * \\ \text { PF.R S.AP. }\left(10^{6} \text { B.tu }\right) & 45.8 & 38.2 & 91.9 & 70.5 & .5 & 35.8 & 262.4\end{array}$

*Electricity omitted to avold double counting. 
TABLE 28

DISTRIBUTION OF ENERGY CONSUMPTION FOR NEW JERSEY (PERCENT)

$\begin{array}{lrrrrrrr}\text { FUEL } & \text { RES. } & \text { COM. } & \text { IND. } & \text { TRAN. } & \text { AGRIC. } & \text { UTTITIY } & \text { TOTAL * } \\ \text { ELECTRICITY } & 14.8 & 17.1 & 7.6 & .0 & .0 & .0 & .0 \\ \text { PETROLEUM } & 45.3 & 63.2 & 83.9 & 99.9 & 100.0 & 63.3 & 82.2 \\ \text { NAT. GAS } & 39.9 & 19.7 & 8.3 & .1 & .0 & 3.1 & 13.2 \\ \text { COAL } & .0 & .0 & .2 & .0 & .0 & .21 .8 & 3.0 \\ \text { NUCLEAR } & .0 & .0 & .0 & .0 & .0 & 12.6 & 1.7 \\ \text { HYDRO } & .0 & .0 & .0 & .0 & .0 & -1.1 & -.2 \\ \text { TOTAL } & 100.0 & 100.0 & 100.0 & 100.0 & 100.0 & 100.0 & 100.0\end{array}$

*Electricity omitted to avoid double counting.

TABLE 29

PEKCENTAGE MIX OF FUELS USED BY ELECTRIC UTILITIES

$\begin{array}{rrrrrr} & \text { OIL } & \text { GAS } & \text { CONL } & \text { NUCLEAR } & \text { HYDRO } \\ 1960 & 37.4 & 13.3 & 19.1 & .0 & .2 \\ 1970 & 57.0 & 10.9 & 24.6 & 8.4 & -1.0 \\ 1975 & 63.3 & 3.4 & 21.8 & 12.6 & -1.1\end{array}$

About $59 \%$ as much coal was used by the utilities in 1975 as was used in 1960; but about $124 \%$ more o1l was used in 1975 than in 1960 .

Energy Supply

There is no significant production of energy resources in New Jersey.

Prices

Prices for selected fuels are shown in Table 30 . The cost of gas to utilities in New Jersey has not increased as much (either in absolute or percentage terms) as in the U.S., but the increase in the cost of gas to 
industry has been astounding. In 1972 gas to industry in New Jersey cost about 24\% less than the corresponding national price. In 1975 the price in the state had risen to about $63 \%$ above the national average.

\section{Other Data}

General economic, demographic, and climatic characteristics are shown in Table 31. Per capita income in New Jersey in 1975 was $13 \%$ above the national average. The unemployment rate was $20 \%$ higher than the national average (10.2 vs 8.5$)$. 
TABLE .30

A COMPARISON OF AVERAGE PRICES PAID FOR

SELECTED ENERGY PRODÏCTS ${ }^{4}$

NEW JERSEY

Fuel

1972

1975

Percent Increase

oil

Reoidential - Retall (NYC area)
( $\$ / 100$ gallons)
20.4
43.42
$112 \%$

Ut111ty

$(\$ / B b 1)$

4.25

12.83

$202 \%$

Gas

Residential
( $\left.\$ / 10^{6} \mathrm{Btu}\right)$
1.78
2.59
$46 \%$

Commercial

$$
\text { (S/10 } 6 \text { Btu) }
$$

1.45

2.26

$56 \%$

Industrial

$$
\left(\$ / 10^{6} \mathrm{Btu}\right)
$$

.34

1.61

$374 \%$

Utility

$$
\text { (c/MCF) }
$$

57.2

90.5

$72 \%$

Coal - Utility

$$
\text { ( } \$ / \text { ton) }
$$

16.26

40.52

$149 \%$

Gasoline - Kegular (NYC area)

$$
\text { (r/galion) }
$$

$37.57 \quad 61.15$

$63 \%$

Electricity

Total Utilit.y Fossil Fuel Cost.s

$$
\text { ( } c / \mathrm{K} \text { wh })
$$

.76

2.13

$180 \%$

Resiảential

$$
\text { (c/Kwh) }
$$

3.06

4.92

$61 \%$

Commercial and Industrial

Sma11 ( $c /$ Kwh)

$2: 73$

4.6

$69 \%$

Large ( $c / K w h)$

1.61

3.18

$98 \%$

Total Sales

$$
\text { (c/Kwh) }
$$

2.46

4.26

$73 \%$

Consumer Price Index $(1967=100)$

NYC area

$131.4 \quad 166.6$ 
TABLE 31

GENERAL ECONOIIC AND DEMOGRAPHIC CHARACTERISTICS

OF NEW JERSEY IN $1975^{6}$

Population (thousands)

7,316

Land Area (Square Mile)

7,521

Population Per Square Mile

972.7

Labor Force (Thousands)

3,202

Employment (Thousands)

2,875

Unemployment Rate (\%)

10.2

Personal Incoine $\left(10^{9}-1975\right.$ Dollars $)$

48.5

Per Capita Income (1975 dollars)

6,629

Heating Degree Days

Atlantic City

1976-77 Heating Season ${ }^{*} \quad 5,283$

Percent above Normal

22

Percent above 1975-76 Heating

Trenton

1975-76 Heating Season

5,133

Percent Above Normal

18

Percent Above 1975-76 Heating

34

*Accumulation froin July I to March 29. 
New York

Energy Demand

Gross energy demand grew at an average rate of $3.8 \%$ per year from 1960 to 1970. From 1970 to 1975 the consumption of energy decreased at about $2.4 \%$ per year.

Energy consumption data, which include estimates of fuels used for feedstocks; are shown in Table 32. Electricity consumption is omitted from the glatud total encry to avoid double counting since resources used to generate electricity are included.

The percentage of total consumption in each sector that is met by a particular fuel is shown in Table 33. The very heavy reliance on petroleum is clear. The transportation sector alone uses about $36 \%$ of all the petroleum used in the state. Utilities are the next largest users, accounting for about $21 \%$ of total petroleum consumption.

Demand for electricity grew at $5.9 \%$ per year from 1960 to 1970 . This high growth rate dropped to $1.8 \%$ per year from 1970 to 1975 . The mix of fuels used by the electric utilities is shown in Table 34 .

TABLE 32

NEW YORK ENERGY CONSUMPTION IN $1975^{1}$

(1012 Dtu)

$\begin{array}{lrrrrrrr}\text { FUEL } & \text { RES. } & \text { COM. } & \text { IND. } & \text { TRAN. } & \text { AGRIC. } & \text { UTILITY } & \text { TOTAL } \\ \text { ELECTRICITY } & 97.9 & 126.3 & 9.7 .5 & 8.2 & .0 & .0 & 325.9 \\ \text { PETROLEUM } & 448.1 & 381.5 & 356.4 & 982.0 & 13.9 & 569.9 & 2751.8 \\ \text { NAT. GAS } & 337.9 & 132.4 & 117.4 & 3.0 & .0 & 14.0 & 604.7 \\ \text { COAL } & 1.4 & .8 & 155.0 & .0 & .0 & 146.0 & 303.3 \\ \text { NUCLEAR } & .0 & .0 & .0 & .0 & .0 & 137.6 & 137.6 \\ \text { HYDRO } & .0 & .0 & .0 & .0 & .0 & 292.3 & 292.3 \\ \text { TOTAL } & 885.3 & 641.0 & 722.3 & 993.2 & 13.9 & 1159.8 & 4089.7 \\ \text { PER CAP. }\left(10^{6} \mathrm{Btu}\right) & 48.9 & 35.4 & 39.9 & 54.8 & .8 & 64.0 & 225.7\end{array}$

*Electricity omitted to ayoid double counting. 
TABLE 33

DISTRIBUTION OF ENERGY CONSUMPTION FOR NEW YORK

(PERCENT)

\begin{tabular}{lrrrrrrr} 
FUEL & RES. & \multicolumn{1}{c}{ COM. } & IND. & TRAN. & AGRIC. & UIITTY & TOTAL $^{*}$ \\
ELECTRICITY & 11.1 & 19.7 & 12.9 & .8 & .0 & .0 & .0 \\
PETROLEUM & 50.6 & 59.5 & 49.3 & 98.9 & 100.0 & 49.1 & 67.3 \\
NAT. GAS & 38.2 & 20.7 & 16.3 & .3 & .0 & 1.2 & 14.8 \\
COAL & .2 & .1 & 21.5 & .0 & .0 & 12.6 & 7.4 \\
NUCLEAR & .0 & .0 & .0 & .0 & .0 & 11.9 & 3.4 \\
HYDRO & .0 & .0 & .0 & .0 & .0 & 25.2 & 7.1 \\
TOTAL & 100.0 & 100.0 & 100.0 & 100.0 & 100.0 & 100.0 & 100.0
\end{tabular}

*Electricity omitted to avoid double counting.

TABLE 34

PERCENTAGE MIX OF FUELS USED BY ELECTRIC UTILITIES

$\begin{array}{lllccc} & \text { OIL } & \text { GAS } & \text { COAL } & \text { NUCLEAR } & \text { HYDRO } \\ 1960 & 11.9 & 10.8 & 55.3 & .0 & 22.0 \\ 1970 & 35.1 & 10.2 & 26.4 & 4.2 & 24.1 \\ 1975 & 49.1 & 1.2 & 12.6 & 11.9 & 25.2\end{array}$

Energy Supply

Table 35 shows the 1975 reserve and production estimates for energy resources extracted in New York. 
TABLE 35

NEW YORK ENERGY RESOURCES - 1975

$10^{12}$ Btu

$\begin{array}{lcc} & \text { OIL } & \text { GAS } \\ \text { Reserves } & 58 & 221 . \\ \begin{array}{l}\text { Production } \\ \begin{array}{l}\text { Reserve/Prodiction } \\ \text { Ratio }\end{array}\end{array} & 5.1 & 6.8 \\ & 11 & 33\end{array}$

Prices

Prices for selected fuels are shown in Table 36.

Other Data

General economic, demographic, and climatic characteristics are shown in Table 37. Per capita income was $13 \%$ higher than the national average in 1976, but the unemployment rate was almost $19 \%$ above the national average (10. $1 \%$ vs $8.5 \%)$. 
TABLE 36

A COMPARISON OF AVERAGE PRICES PAID FOR

SELECTED ENERGY PRODUCTS 4

NEW YORK.

Fuel

0 il

1972

1975

43.4

43.1

$112 \%$

( $\$ / 100$ gallons) (Buffalo)

21.6

3.65

12 .

$229 \%$

Gas

Residential

$$
\left(\$ / 10^{6} \mathrm{Btu}\right)
$$

1.60

2.43

$52 \%$

Commercial

$$
\left(\mathrm{s} / 10^{6} \mathrm{Btu}\right)
$$

1,42

2.04

$44 \%$

Industrial

$$
\left(\$ / 10^{6} \mathrm{Btu}\right)
$$

.91

$$
1.43
$$

$57 \%$

Utility

$$
\text { (c/Mcf) }
$$

56.6

110.6

$95 \%$

Coal - Ut1lity

$$
\text { (\$/ton) }
$$

12.6

29.43

$134 \%$

Gasoline - Regular (NYC area) (c/gallon) (Buffalo)

37.57

61.15

$63 \%$

$71 \%$

Electricity

Total Utility Fossil Fuel Costs

$$
(c / \mathrm{Kwh})
$$

.66

1.93

$192 \%$

Residential

$$
\text { ( } c / k w h)
$$

\subsection{6}

5.13

$58 \%$

Commercial and Industrial

$$
\begin{aligned}
& \text { Small ( } c / \text { Kwh) } \\
& \text { Large ( } c / \text { Kwh) } \\
& \text { Total Sales } \\
& \text { ( } c / \text { Kwh) }
\end{aligned}
$$

3.25

5.27

$62 \%$

1.34

2.52

$88 \%$

2.59

4.41

$71 \%$

Consumer Price Index (NYC area)

$131.4 \quad 166.6$

$27 \%$

$$
\begin{array}{lll}
\text { (Buffalo) } & 126.6 & 161.8
\end{array}
$$


TABLE 37

GENERAI ECONOHIC AND LEMOGRAPHIC CHARACTERISTICS

OF NEW YORK IN 1975

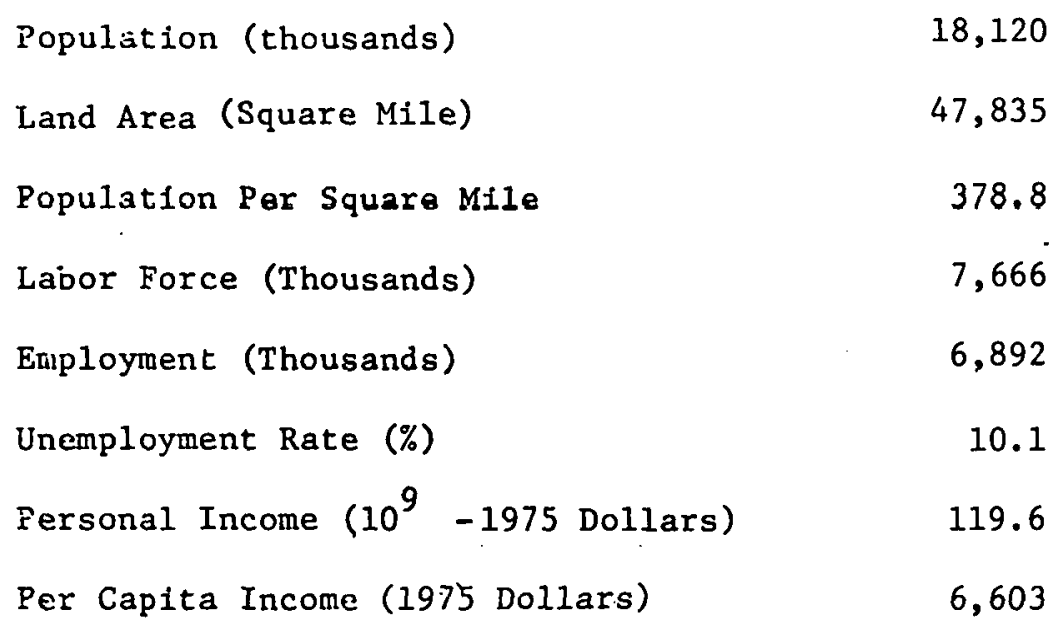


$\underline{\text { Ohio }}$

Energy Demand

Gross energy demand grew at an average rate of $3.3 \%$ per year from 1960 to 1970. From 1970 to 1975, consumption fell slightly at an average rate of about . $3 \%$ per year.

Energy consumption data, which includes estimates of fuels used for feedstocks, are shown in Table 38. Electricity consumption is omitted from the grand total entry to avoid double counting since resources used to generate electricity are included.

The percentage of total consumption in each sector that is met by a particular fuel is shown in Table 39. Despite the fact that a large percentage of demand is met with oil and gas in Ohio, these percentages are less than the national average. However, Ohio meets approximately $22 \%$ more of its energy demand with coal than is the case for the U.S. as a whole. Over $60 \%$ of the gas consumed in Ohio in 1975 was used in the residential and commercial sectors. Utilities used about $64 \%$ of the coal and the transportation sector used about $57 \%$ of the petroleum.

Industrial consumption of natural gas grew about 55\% from 1960 to 1975. Residential and commercial consumption of gas increased $25 \%$ over the same period.

Demand for electricity grew at $4 \%$ per year from 1960 to 1970 , and about $4.4 \%$ per year from 1970 to 1975 . Demand declined at .9\% per year from 1973 to 1975. The mix of fuels used by the electric utilities is shown in Table 40. Utility preference for coal is clear.

Energy Supply

Table 41 shows the 1975 reserve and production estimates for energy resources extracted in ohio.

Unfortunately, less than $1 \%$ has a sulfur content under $1 \%$. About $60 \%$ has a sulfur content greater than $3 \%$.

\section{Prices}

Prices for selected fuels are shown in Table 42. While coal prices rose more in Uhfo than nationally, Lhe lupact on energy prices in Ohio wao less than the impact that oil price increases had on energy prices in other parts of the U.S. that are more dependent on o1l. 
TABLE 38

OHIO ENERGY CONSUMPTION IN $1975^{1}$

$$
\left(10^{12} \mathrm{Btu}\right)
$$

\begin{tabular}{lrrrrrrr} 
FUEL & \multicolumn{1}{c}{ RES. } & \multicolumn{1}{c}{ COM. } & IND. & TRAN. & AGRIC. & UTILITY & TOTAL \\
ELECTRICITY & 95.6 & 76.4 & 184.5 & .1 & .0 & .0 & 356.6 \\
PETROLEUM & 101.7 & 55.7 & 357.0 & 745.4 & 18.3 & 23.7 & 1301.8 \\
NAT. GAS & 441.5 & 174.8 & 364.2 & 9.3 & .0 & 6.3 & 996.1 \\
COAL & 12.6 & 6.8 & 556.0 & .0 & .0 & 1004.6 & 1580.0 \\
NUCLEAR & .0 & .0 & .0 & .0 & .0 & .0 & .0 \\
HYDRO & .0 & .0 & .0 & .0 & .0 & .1 & .1 \\
TOTAL & 651.4 & 313.7 & 1461.6 & 754.8 & 18.3 & 1034.7 & $3878.0 *$ \\
PER CAP. $\left(10{ }^{6}{ }^{\mathrm{Btu}}\right)$ & 60.5 & 29.2 & 135.9 & 70.2 & 1.7 & 96.2 & 360.4
\end{tabular}

TABLE 39

DISTRIBUTION OF ENERGY CONSUMPTION FOR OHIO

(HEKK'E'NI')

\begin{tabular}{|c|c|c|c|c|c|c|c|}
\hline FIIFI. & RES. & SMM. & IND. & TIRAN. & AGRIC. & UTIITTY & TOTAL * \\
\hline ELECTRICITY & 14.7 & 24.4 & 12.6 & .0 & .0 & .0 & .0 \\
\hline PETROLEUM & 15.6 & 17.8 & 24.4 & 98.8 & 100.0 & 2.3 & 33.6 \\
\hline NAT. GAS & 67.8 & 55.7 & 24.9 & 1.2 & .0 & .6 & 25.7 \\
\hline COAL & 1.9 & 2.2 & 38.0 & .0 & .0 & 97.1 & 40.7 \\
\hline NUCLEAR & .0 & .0 & .0 & .0 & .0 & .0 & .0 \\
\hline HYDRO & .0 & .0 & .0 & .0 & .0 & .0 & .0 \\
\hline TOTAL & 100.0 & 100.0 & 100.0 & 100.0 & 100.0 & 100.0 & $100.0 *$ \\
\hline
\end{tabular}


TABLE 40

\begin{tabular}{rrrrrr}
\multicolumn{5}{c}{ PERCENTAGE MIX } & OF FUELS USED BY ELECTRIC UTILITIES \\
& OIL & GAS & COAL & NUCLEAR & HYDRO \\
1960 & .3 & .6 & 99.1 & .0 & .0 \\
1970 & 1.1 & 2.6 & 96.3 & .0 & .0 \\
1975 & 2.3 & .6 & 97.1 & .0 & .0
\end{tabular}

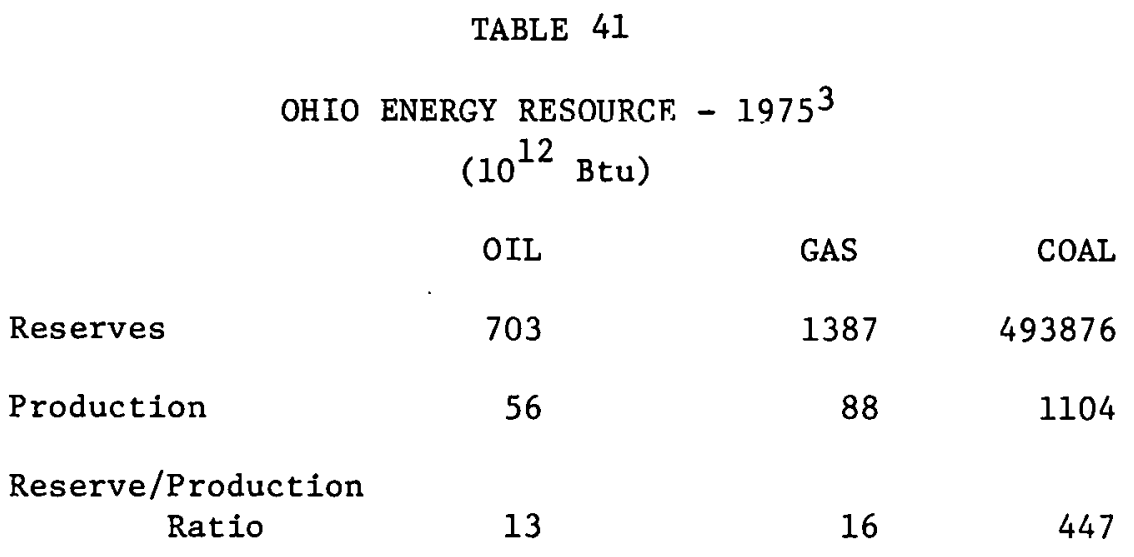


TABLE 42

A COMPARISON OF SELECTED AVERAGE PRICES ${ }^{4}$

OHIO

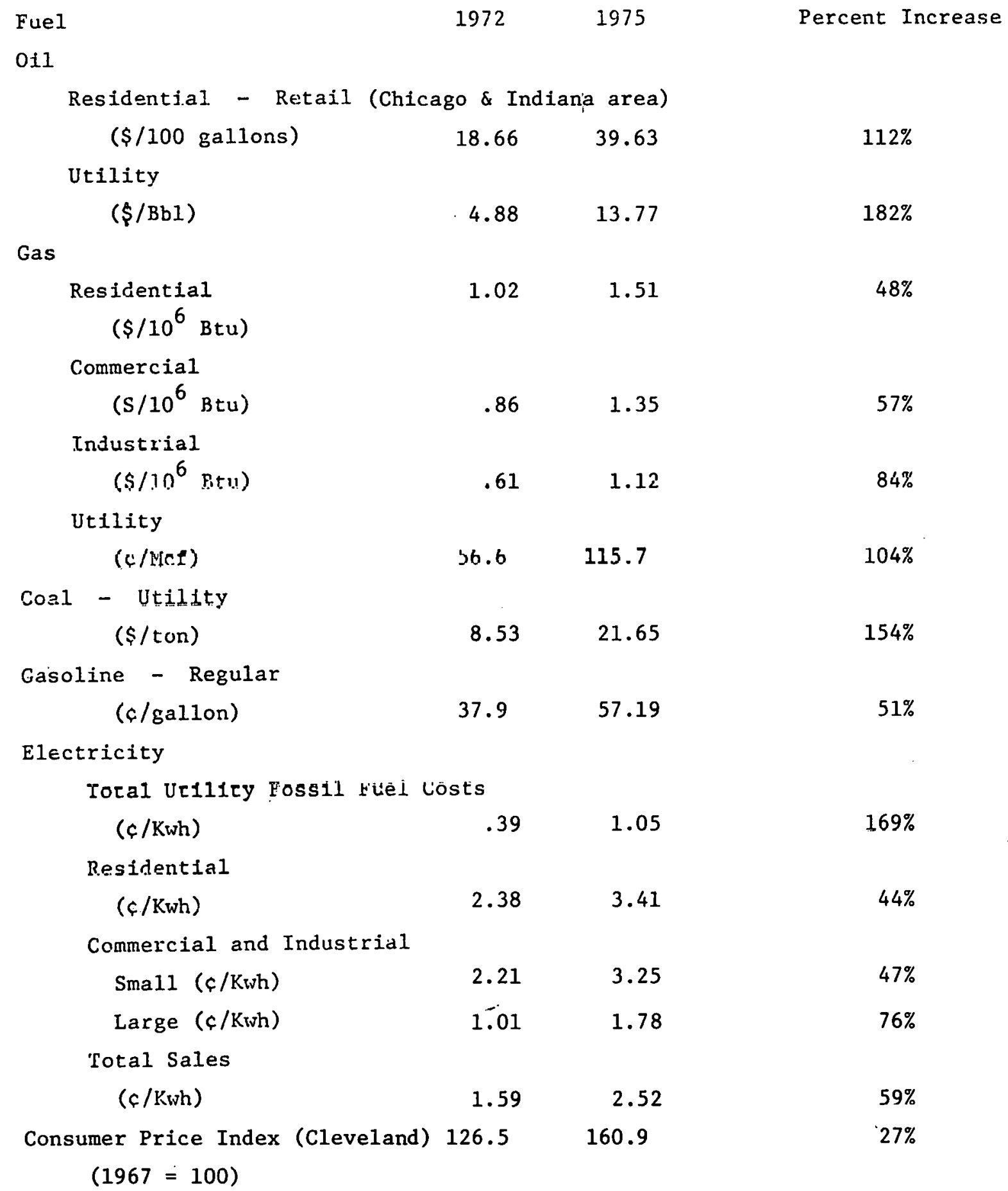




\section{Other Data}

General economic, demographic, and climatic characteristics are shown in Table 43. Per capita income was less than $1 \%$ above the national average in 1975. The unemployment rate was about the same as the national average. Heating degree days in parts of Ohio this past winter were $25 \%$ above normal. The shock of this cold weather was even greater since it came after a period of warmer than normal winters. Heating degree days through March of this past winter in Cincinnati were $45 \%$ above the level of the previous winter. 
TABLE 43

GENERAL ECONOHIC AND DEMOGRAPHIC CHARACTERISTICS 6

OF OHIO IN 1975

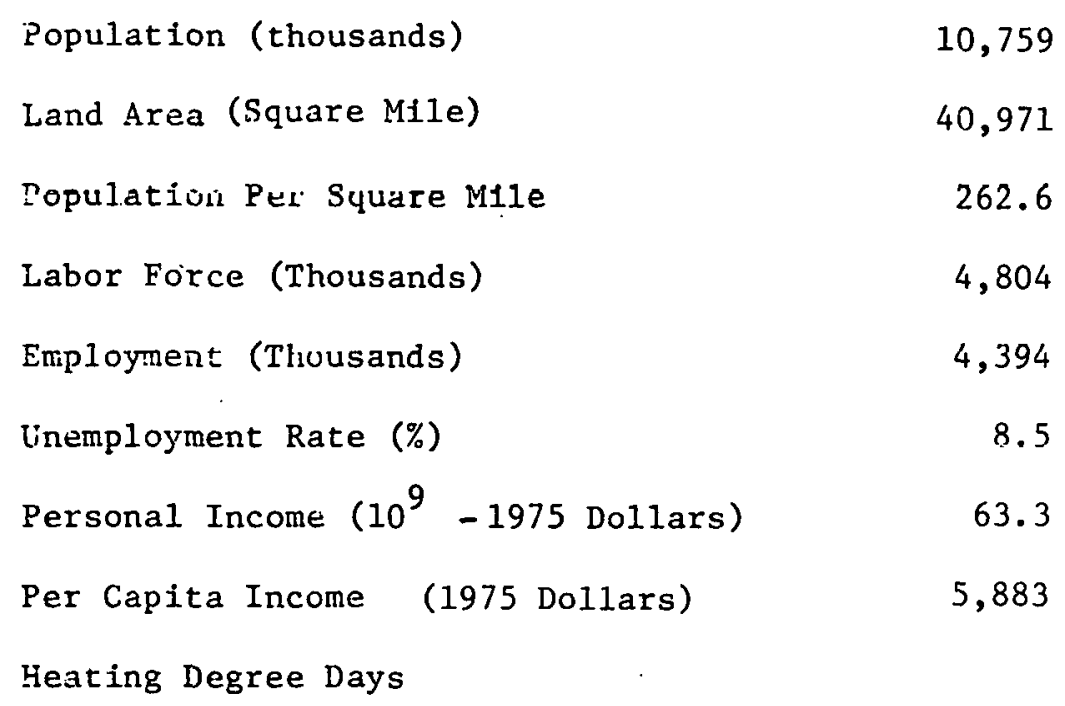


$\underline{\text { Pennsylvania }}$

Energy Demand

Gross energy demand grew at an average rate of $2.7 \%$ per year from 1960 to 1970 . From 1970 to 1975 consumption declined slightly at .4\% per year.

Energy consumption data, which includes estimates of fuels used for feedstocks, are shown in Table 44. Electriclty consumption is omfted from the grand total entry to avold double counting since resources use to generate electricity are included.

The percentage of total consumption in each sector that was met by a particular fuel in 1975 is shown in Table 45. While a large percentage of energy demand was met with petroleum in 1975 , about $21 \%$ more of the total energy demand was met with coal in Pennsylvania than was typical for the U.S. Natural gas is used extensively in the residential sector and use In this and the commercial sector accounted for about $56 \%$ of the total gas consumed in 1975 . The industrial sector used about $40 \%$. About $48 \%$ of the petroleum was used in the transportation sector. The industrial and utility sectors each used about half of coal consumed in the state.

Demand for electricity grew at $6.8 \%$ per year from 1960 to 1970 and at about 3.1\% from 1970 to 1975. Demand declined slightly from 1973 to 1975. The mix of fuels used by the electric utilities is shown in Table 46.

TABLE 44

PENNSYLVANTA ENERGY CONSUMPTION IN $1975^{1}$

\begin{tabular}{|c|c|c|c|c|c|c|c|}
\hline \multicolumn{8}{|c|}{$\left(10^{12} \mathrm{Btu}\right)$} \\
\hline FUEL & RES. & COM. & IND. & TRAN. & AGRIC. & UTITITY & TOTAL \\
\hline ELECTRICITY & 94.6 & 61.7 & 141.0 & 3.1 & .0 & .0 & 300.4 \\
\hline PETROLEUM & 181.5 & 143.7 & 355.7 & 736.4 & 20.3 & 92.8 & 1530.4 \\
\hline NAT. GAS & 281.4 & 102.2 & 273.8 & 18.3 & .0 & 1.3 & 677.0 \\
\hline COAL & 4.0 & 2.2 & 745.0 & .0 & .0 & 834.9 & 1586.0 \\
\hline NUCLEAR & .0 & .0 & .0 & .0 & .0 & 166.7 & 166.7 \\
\hline HYDRO & .0 & .0 & .0 & .0 & .0 & 16.4 & 16.4 \\
\hline TOTAL & 561.5 & 309.8 & 1515.4 & 757.8 & 20.3 & 1112.1 & 3976.5 * \\
\hline PER CAP. $\left(10^{6} \mathrm{Btu}\right)$ & 47.5 & 26.2 & 128.1 & 64.1 & 1.7 & 94.0 & 336.2 \\
\hline
\end{tabular}


TABLE $\cdot 45$.

DISTRIBUTION OF ENERGY CONSUMPTION FOR PENNSYLVANIA (PERCENT)

\begin{tabular}{lrrrrrrr} 
FUEL & \multicolumn{1}{c}{ RES. } & COM. & IND. & IRAN. & AGRIC. & \multicolumn{1}{l}{ UTITITY } & TOTAL * \\
ELECTRICITY & 16.8 & 19.9 & 9.3 & .4 & .0 & .0 & .0 \\
PETROLEUM & 32.3 & 46.4 & 23.5 & 97.2 & 100.0 & 8.3 & 38.5 \\
NAT. GAS & 50.1 & 33.0 & 18.1 & 2.4 & .0 & .1 & 17.0 \\
COAL & .7 & .7 & 49.2 & .0 & .0 & 75.1 & 39.9 \\
NUCLEAR & .0 & .0 & .0 & .0 & .0 & 15.0 & 4.2 \\
HYDRO & .0 & .0 & .0 & .0 & .0 & 1.5 & .4 \\
TOTAL & 100.0 & 100.0 & 100.0 & 100.0 & 100.0 & 100.0 & 100.0
\end{tabular}

*Electricity omitted to avoid double counting.

TABLE 46

PERCENTAGE MIX OF FUELS USED BY ELECTRIC UTILITIES

$\begin{array}{rrrrrr} & \text { OIL } & \text { GAS } & \text { COAL } & \text { NUCLEAR } & \text { HYDRO } \\ 1960 & 5.1 & 1.5 & 89.0 & .0 & 4.4 \\ 1970 & 19.4 & 1.1 & 77.4 & .6 & 1.5 \\ 1975 & 8.3 & .1 & 75.1 & 10.0 & 1.5\end{array}$

Coal consumption grew by $120 \%$ from 1960 to 1975 in the utility sector. Uil consumption grew by $330 \%$ over the same period but st 111 only accounted for $8.3 \%$ of the resources used in 1975 .

Wieregy Supply

Table 47 shows the 1975 reserve and production estimates for energy resources extracted in Pennsylvania. 


\begin{tabular}{|c|c|c|c|c|}
\hline \multicolumn{5}{|c|}{$\begin{array}{l}\text { PENNSYLVANIA ENERGY RESOURCES }-1975 \\
\left(10^{12} \mathrm{Btu}\right)\end{array}$} \\
\hline & OIL & NGL & GAS & CQAL \\
\hline Reserves & 279 & 2.1 & 1723 & 806020 \\
\hline Production & 18.6 & .27 & 87 & 2349 \\
\hline $\begin{array}{c}\text { Reserve/Production } \\
\text { Ratio }\end{array}$ & 15 & 8 & 20 & 422 \\
\hline
\end{tabular}

About $24 \%$ of the coal has a sulfur content under $1 \%$. Over $54 \%$ has a sulfur content between 1 and $3 \%$.

\section{$\underline{\text { Prices }}$}

Prices for selected fuels are shown in Table 48. Although the cost of coal to utilities rose more in the state between 1972 and 1975 than the U.S. average, the increase was less than the increase in prices utilities paid for petroleum. This fact, and the fact that utilities in the state rely heavily on coal, help explain why total utility fossil fuel costs rose less than the national average.

\section{Other Data}

General economic, demographic, and climatic characteristics are shown in Table 49. Per capita income in Pennsylvania was about the same as the U.S. average in 1975 . Unemployment was slightly higher $(8.9 \%$ vs $8.5 \%$ for the U.S.). 


\section{TABLE 48}

A COMPARISON OF AVERAGE PRICES PAID FOR

$$
\text { SELECTED ENERGY PRODUCTS } 4
$$

PENNSYLVANIA

\begin{tabular}{|c|c|c|c|}
\hline Fue1. & 1972 & 1975 & Percent Increase \\
\hline \multicolumn{4}{|l|}{011} \\
\hline \multicolumn{4}{|c|}{ Residential - Retail } \\
\hline (\$/100 ga1lons) & 19.23 & 41.03 & $113 \%$ \\
\hline \multicolumn{4}{|l|}{ Utility } \\
\hline$(\$ / B b 1)$ & 4.37 & 13.11 & $200 \%$ \\
\hline \multicolumn{4}{|l|}{ Gas } \\
\hline \multicolumn{4}{|l|}{ Residential } \\
\hline$\left(\$ / 10^{6} R+11\right)$ & 1.33 & 1.90 & $43 \%$ \\
\hline \multicolumn{4}{|l|}{ Commercial } \\
\hline$\left(\mathrm{s} / 10^{6} \mathrm{Btu}\right)$ & 1.08 & 1.66 & $54 \%$ \\
\hline \multicolumn{4}{|l|}{ Industrial } \\
\hline$\left(\$ / 10^{6} \mathrm{Btu}\right)$ & .69 & 1. .41 & $104 \%$ \\
\hline \multicolumn{4}{|l|}{ Utility } \\
\hline$(c / M c f)$ & 69.2 & 139.2 & $101 \%$ \\
\hline \multicolumn{4}{|l|}{ Coal - Utility } \\
\hline$(\$ /$ ton $)$ & 9.89 & 22.7 & $130 \%$ \\
\hline \multicolumn{4}{|l|}{ Gasoline - Regular } \\
\hline (c/gallon) & 36.7 & 53.9 & $47 \%$ \\
\hline \multicolumn{4}{|l|}{ Electricity } \\
\hline \multicolumn{4}{|c|}{ Total Utility Fossil Fuel Costs } \\
\hline$(\phi /$ Kwh $)$ & .48 & 1.1 & $129 \%$ \\
\hline \multicolumn{4}{|l|}{ Residential } \\
\hline$(c / K w h)$ & 2.77 & 4.0 & $44 \%$ \\
\hline \multicolumn{4}{|c|}{ Commercial and Industrial } \\
\hline Small (c/Kwh) & 2.46 & 3.63 & $48 \%$ \\
\hline Large (c/Kwh) & 1.42 & 2.53 & $78 \%$ \\
\hline \multicolumn{4}{|l|}{ Total Sales } \\
\hline$(c / \mathrm{Kwh})$ & 2.04 & 3.25 & $59 \%$ \\
\hline \multicolumn{4}{|c|}{ Consumer Price Index $(1967=100)$} \\
\hline Phtladelphia & 127.0 & 164.2 & $29 \%$ \\
\hline P1ttsburgh & 125.3 & 160.0 & $28 \%$ \\
\hline
\end{tabular}


GENERAL ECONO:IIC AND DEMOGRAPHIC CHARACTERISTICS

OF PENNSYLVANIA IN 1975

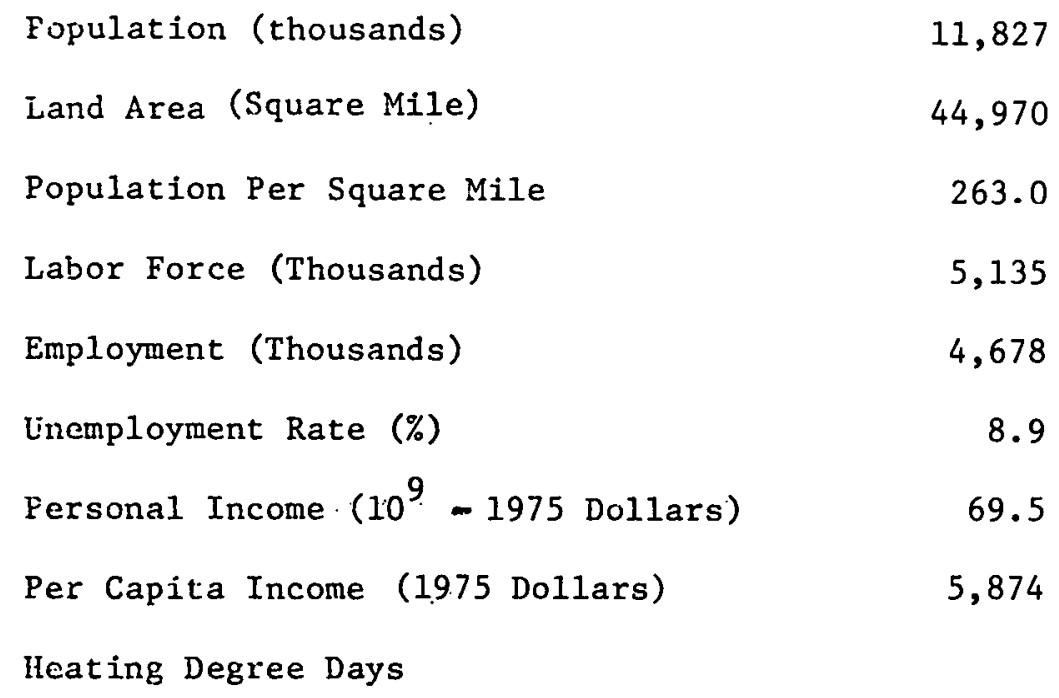

\section{Harrisburg}

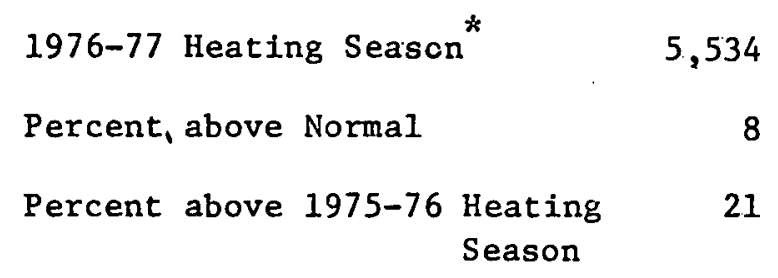

Pittsburgh

1975-76 Heating Season 6,976

Percent Above Normal 22

Percent Above 1975-76 Heating 33

*Accumulation from July 1 to May 1. 
Puerto Rico

Energy Supply and Demand

Calendar year 1976 showed an increase in the consumption of most fuel products except for residual and naphtha. During calendar year 1976, wholesale distributors in Puerto Rico sold a total of 24.5 million barrels (mmb) of refined products. This figure represents an additional increase of $1.7 \mathrm{mmb}$. over last year. In particular, motor gasoline sales increased by $7.9 \%$; (equivalent to $1.1 \mathrm{mmb}$ ). Residual fuels consumption ( $65.7 \%$ of the total for electricity generation, and $34.3 \%$ by the remaining sectors) registered a reduction with respect to 1975. In 1976, the decrease was $7.6 \%$ as compared with 1975. There have been no shortfalls or curtailments of energy supplies in Puerto Rico. The consumption (by sector) of petroleum products is shown in Table 50 .

Table jo

PETROLEUM CONSUMPTION

$\begin{array}{lrr}\text { Sector of Consumption } & (\%) \\ \text { Electricity Generation } & & \\ \text { Transportation } & 1.8 .0 & 17.2 \\ \text { Manufacture } & 17.6 & 16.8 \\ \text { Others } & 22.7 & 21.7 \\ \text { Subtotal } & \frac{3.6}{61.9} & \frac{3.4}{59.2} \\ \text { Exports Total } & \frac{42.7}{104.6} & \frac{40.8}{00.0}\end{array}$

\footnotetext{
${ }^{\mathrm{a} C o n s u m e d ~ E l e c t r i c i t y ~ a t t r i b u t e d ~ t o ~ t h e ~ m a n u f a c t u r i n g ~ s e c t o r ~}(2.8 \mathrm{mmb}-$ and to the "Others" sector $(3.5 \mathrm{mmb})$; losses of $1.9 \mathrm{mmb}$ attributed to manufacturers. Data for electricity. is based on information supplied by refineries. Nevertheless the Water Resources Authority consumed $21.7 \mathrm{mmb}$ and Generated $7.6 \mathrm{mmb}$, which implies additional imports and or utilization of inventories to satisfy consumption requirements. Lost and used energy adapted from U.S, and States Statistics.

* Most of this section has been taken verbatim from "Synopsis of the Energy Situation in Puerto Rico-1976" prepared by The Office of Petroleum Fuels Affairs, office of the Governor, Commonwealth of Puerto Rico.
} 
Puerto Rico is totally dependent on external sources in order to satisfy its needs for the refinery and petrochemical sector. The production of the refining sector of Puerto Rico in 1976 was $75.4 \%$ of capacity. This production not only covers the internal needs for fuels of the island but also provided export requirements for petroleum products which amounted to $42.7 \mathrm{mmb}$ for that year, (Table. 51).

\section{TABLE 51}

SUPPLY AND DEMAND RELATION OF PETRCLEUM PRODUCTS (1976)

$$
\left(10^{6} \mathrm{bbls}\right)
$$

\section{Imports $\quad$ Internal Consumption Exports}

$\begin{array}{lccr}\text { Crude } & 83.1 & & \\ \text { Naptha } & 20.0^{\mathrm{a}} & 4.7 & \\ \text { Refinery Gas } & 0.1 & 5.4 & 12.4 \\ \text { Middle Distillates } & & 6.7 & 6.8 \\ \text { Residual Fuel 0ils } & 0.1 & 24.2 & 14.0 \\ \text { Motor Gasoline } & 0.8 & 15.1 & \\ \text { Aviation Fuel } & 1.1 & 1.8 & 9.6 \\ \text { Others } & 0.2 & 4.1^{\mathrm{b}} & 42.7\end{array}$

a. Includes adjustments in Naptha used by the refineries as petrochemical feedstocks; excludes imports by the petrochemical sector.

b. Includes Loss in Process.

c. Figures may not add to total due to rounding.

Source: Office of Petroleum Affairs, Economic and Planning Division, Puerto Rico 
Up to 1973, Venezuela had been the principal supplier of crude and naphtha. For 1976, participation in crude and naphtha imports was $42.2 \%$ and $44.4 \%$, respectively. Venezuela's participation in total imports of crude and naphtha has been reduced to $42.9 \%$ in favor of imports from Other Foreign Countries and the Middle East (Tahle. 52.);

TABLE 52

PETROLEUM IMPORTS TO PUERTO RICO

Product/Country

of Origin

Crude

Venezuela

Middle East

Other

Naptha

Venezuela

Middle East

and Other

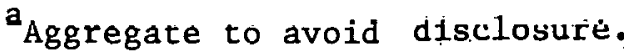

50.7

27.5

21.8

34.4

44.4

65.6

55.6

\section{Energy Prices in Puerto Rico}

Since Puerto Rico imports practically all of its energy raw material and petrochemical feedstocks, OPEC pricing policy reflects upon local prices more severely. than on the mainland. This has caused price increases on raw material that have reversed Puerto Rico's formerly competitive position in petroleum refining, petrochemicals, electricity and steam costs to the point of wiping out benefits induced from oil imports allocations, whose lower priccs also compensated for higher two-way shipping eosts for raw material imports and sales of finished products in the U.S. market. 
Annual acquisition cost for crude and naphtha were $\$ 12.48 / \mathrm{bb} 1$ and $\$ 14.18 / \mathrm{bb} 1$ for Calendar Year 1976, respectively. These acquisition costs have induced increases in the cost of locally produced finished product. In particular, motor gasoline has soared to $0.56 \mathrm{c} / \mathrm{gal}$. for December 1976, and the annual average was $0.54 \mathrm{c} / \mathrm{ga}$. at the wholesale level. At the pump, unleaded gasoline was sold at 72.51 cents/gal. and leaded gasoline was sold at 74.22 cents/gal. during December 1976. Average prices for Calendar Year 1976 were 70.65 cents/ gal. for unleaded and 72.14 cents/gal. for leaded.

For locally consumed energy prouducts, these prices reflect the partial pass through of the supplementary licenses fee retained by the government in order to meet revenue requirements for budget financing. Other decontrolled products consumed locally reflect these impacts.

Table. 53 reflects fuel cost increases to the electric generating sector.

TABLE 53

FUEL PRICES INCREASES

$\begin{array}{lccc}\text { Type } & \text { Feb. } 1976 & \begin{array}{c}\text { Cost }(\$ / \text { Barrel }) * \\ \text { August } 1976\end{array} & \text { Feb. } 1977 \\ \text { Fuel 011-No. } 6 & 11.48 & 12.57 & 13.65 \\ \text { Light Dist111ate } & 14.66 & 15.38 & 18.82 \\ \text { Propane } & 14.91 & 14.91 & 15.75 \\ \text { Diese1 } & - & - & 21.00 \\ \begin{array}{l}\text { *Does Not include handling charge: PRWRA estimates a } 10 \% \text { yearly escelating } \\ \text { factor beginning with fiscal year }\end{array}\end{array}$

Although PRWRA has not revised its rates during the last year, a major component in computing charges for electric services is the cost of fuel oil. The Authorfty's rates for all classes of customers include fuel oil 
adjustment provisions under which adjustments in charges for electric service are made to reflect increases or decreases in fuel oil costs over the base cost of $\$ 2.00$ per barrel (except for three large power users whose base cost is $\$ 3.00$ per barrel as per Special Rate 371 and one power user with $\$ 1.60$ per barrel base cost as per Special Rate 370 - Interruptible Service).

Table 54 includes a comparison of fuel oil adjustment charges to customers during February 1976, August 1976 and February 1977.

\section{TABLE 54}

FUEL OIL ADJUSTMENT

$\$ /$ Kwh

Type of Service

Secondary distribution voltage

Primary distribution voltage

Secondary transmission voltage

Interruptible service (Air Products)

Special Rate 371 (At generating bus bar and base cost of $\$ 3.00$ per barrel)
Feb. 1976

0.024754

0.024082

0.023442

0.020054

0.01761 .2

0.019501

0.020340
Feb. 1977

0.028204

0.027629

0.027072

0.022671

0.022079

Selected Aspects Related to the Economic Activity in Puerto Rico: 1975-76

During this fiscal year, the economy of Puerto Ricn was afferted for the third consecutiye year by various recession-inflation related prohlems which dampened its rate of growth to only $4.8 \%$ in reference to $1974-75$; at constant prices this was reduced to only $1.2 \%$. 
In money terms, the above is equivalent to a GNP of $\$ 7,492.9$ million as compared with $\$ 7,141.1$ the previous year. This is $1.8 \%$ less than the. $6.6 \%$ increase registered for 1974-19.75. In real terms, this corresponds to $\$ 3,430.0$ million for $1975-76$, which implies the rate of $1.2 \%$ referred to above. During this same period, the GNP in current prices in the U.S. grew at a rate of $11 \%$ and at $4 \%$ in real terms. In contrast to the U.S., where monetary growth of GNP was the result of rises in all its components, in Puerto Rico the growth is primarily attributed to the increases registered by personal expenditures, the other components registered either diminished or had a negligible increase.

Total personal income, income from all sources, was $\$ 7,682.1$ million, implying a rise of $12.0 \%$ over last year. This increase, however, was induced primarily by transfer payments. In fact, it is estimated that from the $\$ 824.9$ million increase in personal income, $\$ 570.0$ million, $69.1 \%$ was originated by transfer payments. In the case of income originating from the production process and which goes to personal income, these reached $\$ 5,563.3$ million for $1975-76$; that is, $\$ 254.90$ over last year's.

It is worth noting that within this context, personal expenditure increments in the price index increased by $8.2 \%$ and $9.0 \%$ respectively for motor gasoline and electricity. This compares correspondingly with $25.8 \%$ and $31.4 \%$, and $30.9 \%$ and $38.6 \%$ for $1974-75$ and $1973-74$.

It is of particular interest that the average wage paid in the manufacturing sector for 1976 was $\$ 2.86 / \mathrm{hr}$., whereas, in the mainland the comparable figure was $\$ 5.08 / \mathrm{hr}$.: a difference of $\$ 2.22$.

The unemployment rate for $1975-76$ was $19.4 \%$, which represents around 172,000 people out of jobs from a working force of 890,000 . As shown in Table 55 employment has increased radically over the past 5 years. 
TABLE 55

TOTAL UNEMPLOYMENT AND UNEMPLOYMENT RATE

Fisca1 Year

1971-72

$1972-73$

$1973-74$

1974-75

$1975-76$
Tota1 Unemployed (000)

100.0

101.0

109.0

134.0

172.0

19.4

Source:

Departamento del Trabajo Negociado de Estadisticas Division Grupo Trabejador 


\section{Virginia*}

Energy Demand

Gross energy demand grew at an average rate of $3.6 \%$ per year from 1960

to 1970 and about . $4 \%$ from 1970 to 1975 . Consumption has declined about $4.7 \%$.

per year from 1973 to 1975.

Energy consumption data, which includes estimates of fuels used for feedstocks, are shown in Table 56. Electricity consumption is omitted from the grand total entry in order to avoid double counting since resources used to generate electricity are included.

The percentage of total consumption in each sector that was met by a particular fuel in 1975 is shown in Table 57. Table 58 shows the growth of electricity consumption in Virginia over the past ten years.

TABLE 56
VIRGINIA ENERGY CONSUMPTION, $1975^{1}$
$\left(10^{12} \mathrm{Btu}\right)$

FUEL RES.

COM. IND. TRAN. AGRIC. UTIEITY TOTAL ELECTRICITY 52.7 50.1

29.8 .0

$$
.0
$$
$\begin{array}{ll}.0 & 132.6\end{array}$ PETROLEUM 61.6 27.5

191.1

454.3

7.2

175.5

917.2

NAT. GAS

50.4

33.4

43.4

3.2

.5

130.9

COAL 4.0 .

2.1

68.4

NUCLEAR

$: 0$

.0

$95.7 \quad 170.2$

HYDRO

.0

.0

$$
.0
$$

.0

.0

94.2

94.2

TOTAL

168.7

113.1

332.7

.0

.0

13.2

13.2

PER CAP. $\left(10^{6}\right.$ Btu $)$

$34.0 \quad 22.8 \quad 67.0$

457.5

7.2

379.1

$1325.7^{*}$

*Electricity omftted to avold double counting. 
TABLE 57

DISTRIBUTION OF ENERGY CONSUMPTION FOR VIRGINIA

(PERCENT)

\begin{tabular}{|c|c|c|c|c|c|c|c|}
\hline FUEL & RES. & COM. & IND. & TRAN. & AGRIC. & UTIIITY & TOTAL \\
\hline ELECTRICITY & 31.2 & 44.3 & 9.0 & .0 & .0 & .0 & .0 \\
\hline PETROLEUM & 36.5 & 24.3 & 57.4 & 99.3 & 100.0 & 46.3 & 69.2 \\
\hline NAT. GAS & 29.9 & 29.5 & 13.0 & .7 & .0 & .1 & 9.9 \\
\hline COAL & 2.4 & 1.9 & 20.6 & .0 & .0 & 25.2 & 12.8 \\
\hline NUCLEAR & .0 & .0 & .0 & .0 & .0 & 24.9 & 7.1 \\
\hline HYDRO & .0 & .0 & .0 & .0 & .0 & 3.5 & 1.0 \\
\hline TOTAL & 100.0 & 100.0 & 100.0 & 100.0 & 100.0 & 100.0 & $100.0^{*}$ \\
\hline
\end{tabular}

*Electricity omitted to avoid double counting.

TABLE 58

CONSUMPTION OF ELECTRICITY: 1965-1974

(millions of kilowatt hours)

Va. U.S. V. U.S.

\begin{tabular}{lrccc} 
Sector & \multicolumn{2}{c}{ Growth } & \multicolumn{2}{c}{ Annun1 frowth Rate } \\
Residential & 8,251 & 273,990 & $9.7 \%$ & $7.9 \%$ \\
Commercial & 4,755 & 190,604 & $8.0 \%$ & $1.7 \%$ \\
Industrial & 3,701 & 256,070 & $6.1 \%$ & $5.3 \%$ \\
\multicolumn{1}{c}{ TOTAL } & 19,474 & 747,355 & $8.9 \%$ & $6.6 \%$
\end{tabular}

Over $69 \%$ of Virginia's energy demand in 1975 was met with petroleum as compared with about $46 \%$ for the U.S. About half of the petroleum was used in the transportation sector. The industrial and utility sectors

* Some of the information in this section comes from a report prepared for this briefing document by Patricia Rice of ORNL. 
usped about $20 \%$ each. Over $60 \%$ of the natural gas used in the state was consumed in the residential and commercial sectors. Industries used about $33 \%$. Over $56 \%$ of the coal was used by the utilities and over $40 \%$ was used by industries.

Demand for electricity grew at about $9.8 \%$ per year from 1960 to 1970 and about 5.8\% per year from 1970 to 1975. From 1973 to 1975 growth has been about $2.4 \%$ per year. The mix of fuels used by the electric utilities is shown in Table 59.

\section{TABLE 59}

\begin{tabular}{rrrrrr}
\multicolumn{5}{c}{ PERCENTAGE MIX } & OF FUELS USED BY ELECTRIC UTILITIES \\
& OIL & GAS & COAL & NUCLEAR & HYDRO \\
1960 & .8 & .8 & 91.5 & .0 & 6.9 \\
1970 & 38.5 & 1.5 & 57.6 & .0 & 2.4 \\
1975 & 46.3 & .1 & 25.2 & 24.9 & 3.5
\end{tabular}

Despite the large amount of coal produced in the state (see discussion below), the utilities used about $58 \%$ as much coal in 1975 as they did in 1960 .

Energy Supply

Table 60 shows the 1975 resource and production estimates for energy resources extracted in Virginia.

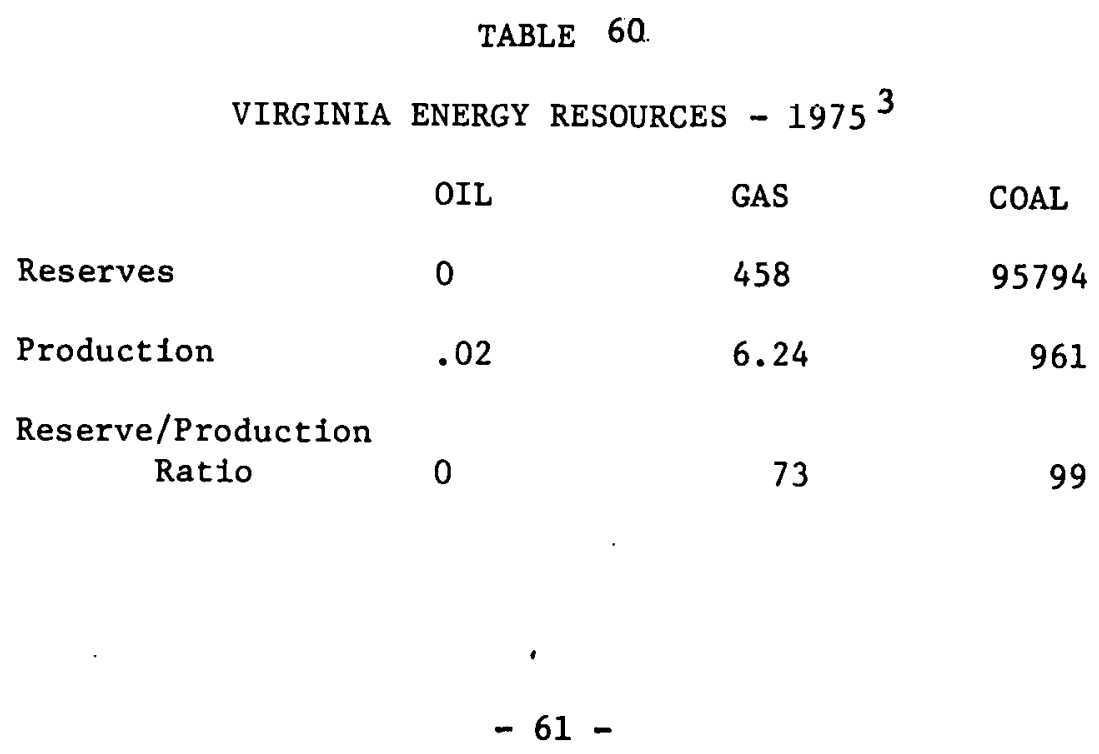


Virginia imports over $80 \%$ of its energy, producing very little petroleum or natural gas. Its only large primary energy resource is coal, located in the southwestern part of the state on the eastern edge of the Appalachian coal field. Over. $58 \%$ of the coal has a sulfur content of less then $1 \%$. Another $32 \%$ has a sulfur content between $1 \%$ and $3 \%$. Despite the large production of coal, consumption of coal in Virginia is relatively low due to the lack of heavy Industry in the state and the extensive use of oil for the generation of electric power.

Prices

Prices for selected fuels are shown in Table 61. One reason utilities do not use more coal may be related to the high cost of coal to utilities in Virginia. In 1975, the price of coal to utilities in Virginia was $55 \%$ higher than the national average. However, petroleum prices faced by utilities were about $5 \%$ less than the national average.

Üther Data

General economic, demographic and climatic characteristics are shown in Table 62. Per capita income in Virginia was almost $3 \%$ below the national average in 1975 . Unemployment was about $19 \%$ less than the U.S. average (6.9\% vs $8.5 \%$ ). 
TABLE 61

A COMPARISON OF AVERAGE PRICES PAID FOR

SELECTED ENERGY PROIICCTS 4

VIRGINIA

\begin{tabular}{|c|c|c|c|}
\hline Fuel & 1972 & 1975 & Percent Increase \\
\hline \multicolumn{4}{|l|}{$0 i 1$} \\
\hline \multicolumn{4}{|c|}{ Residential - Retail (For DC) } \\
\hline (\$/100 gallons) & 19.78 & 42.48 & $115 \%$ \\
\hline \multicolumn{4}{|l|}{ Utility } \\
\hline$(\$ / B b 1)$ & 2.77 & 11.61 & $319 \%$ \\
\hline \multicolumn{4}{|l|}{ Gas } \\
\hline \multicolumn{4}{|l|}{ Residential } \\
\hline$\left(\$ / 10^{6} \mathrm{Btu}\right)$ & 1.62 & 2.29 & $41 \%$ \\
\hline \multicolumn{4}{|l|}{ Commercial } \\
\hline$\left(\mathrm{s} / 10^{6} \mathrm{Btu}\right)$ & 1.16 & 1.80 & $55 \%$ \\
\hline \multicolumn{4}{|l|}{ Industrial } \\
\hline$\left(\$ / 10^{6} \mathrm{BCu}\right)$ & .62 & 1.12 & $81 \%$ \\
\hline \multicolumn{4}{|l|}{ Utility } \\
\hline$(c / M c f)$ & 42.6 & 107.8 & $153 \%$ \\
\hline \multicolumn{4}{|l|}{ Coal - Utility } \\
\hline$(\$ /$ ton $)$ & 10.86 & 29.04 & $167 \%$ \\
\hline \multicolumn{4}{|l|}{ Gasoline - Regular } \\
\hline (c/gallon) & 36.9 & 57.23 & $55 \%$ \\
\hline \multicolumn{4}{|l|}{ Electricity } \\
\hline \multicolumn{4}{|c|}{ Total Ut1lity Fossil Fuel Costs } \\
\hline$(c / K w h)$ & .45 & 1.69 & $276 \%$ \\
\hline \multicolumn{4}{|l|}{ Residential } \\
\hline$(c /$ Kwh $)$ & 2.10 & 3.45 & $64 \%$ \\
\hline \multicolumn{4}{|c|}{ Commercial and Industrial } \\
\hline $\operatorname{Sma11}(c / K w h)$ & 1.97 & 3.40 & $72 \%$ \\
\hline Large $(c /$ Kwh $)$ & 1.16 & 2.33 & $101 \%$ \\
\hline \multicolumn{4}{|l|}{ Total Sales } \\
\hline$(c /$ Kwh $)$ & 1.72 & 3.03 & $76 \%$ \\
\hline \multicolumn{4}{|c|}{ Consumer Price Index $(1967$ - 100) } \\
\hline Washington, D. C. & 126.9 & 161.6 & $27.3 \%$ \\
\hline
\end{tabular}


TABLE 62

GENERAL ECONOMIC AND DEMOGRAPHIC CHARACTERISTICS

OF VIRGINIA IN $1975^{6}$

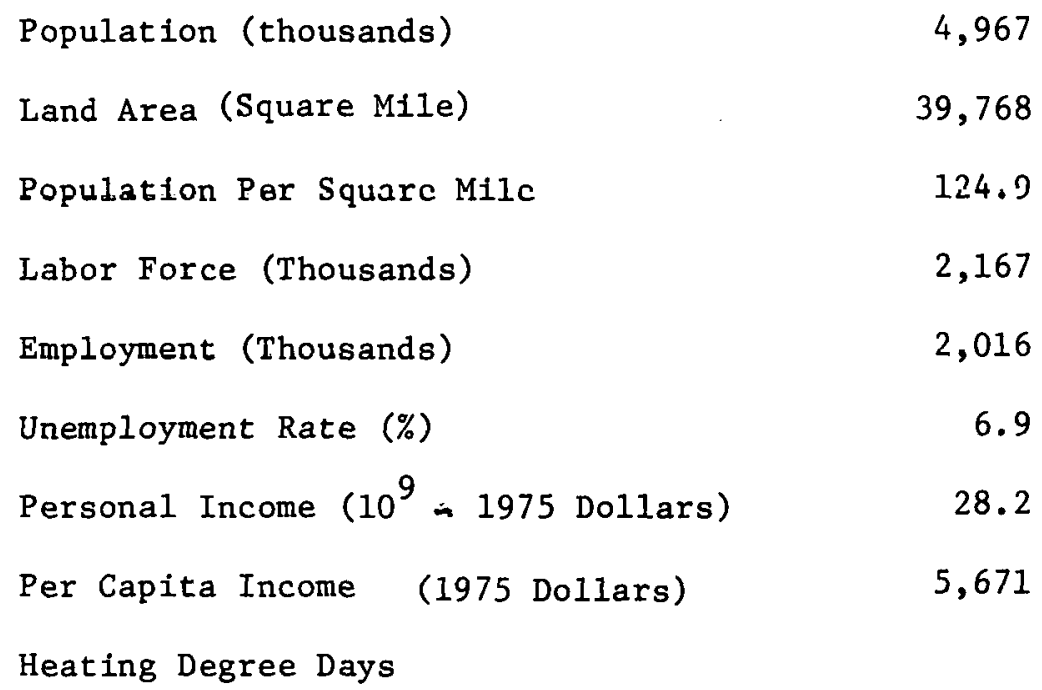




\section{Virgin Islands}

Energy Supply and Demand

Total energy consumption in the Virgin Islands has increased by $77 \%$ since 1970, but appears to be leveling off (Figure 2). In 1975 the islands consumed 125.2 trillion Btu's or approximately $1.74 \%$ of total U.S. consumption. As shown in Figure 10 industry used $83.4 \%$ of the total. The largest industrial consumers and dominant factors in energy use in the islands with $78 \%$ of total consumption are the refining and petrochemical industrles. Of the remaining $16.6 \%$, one third was used in the production of electricity and de-salted water (approximately 1 million bbl's per year) by the V.I. Water and Power Authority (WAPA) at separate facilities on each island (maximum demand for electricity, on each-1́sland, is less than 35 Mwe). Approximately $11 \%$ (the remainder) was consumed in the residential, commercial and transportation sectors.

All energy consumed in the Virgin Islands was imported. Most was derived from imported crude refined to product and consumed in the islands. Some of the imported crude was refined and exported to domestic U.S. markets (156 million bbl's in 1975). Only small amounts of refined product such as aviation gas, gasoline and residual fuel (used in the alumina refinery) were imported to the Virgin Islands (Figure11).

There have been no actual shortfalls or curtailments of petroleum but there have been occasional power outages and water curtailments from WAPA breakdowns. Small size and plant inefficiencies contribute to irregularities in electric supply.

Employment and the Economy

Price changes for energy have been modest relative to cost-of-living increases. Inflation in the Virgin Islands since 1970 has been over double the U.S. rate (58 to $24 \%$ ). A major contributing factor to this difference is the high energy component (importation, storage, and cooling) of most articles sold in the Virgin Islands (virtually all products consumed or sold in the Virgin Islands are imported).

*Taken from the Virgin Islands Conservation Plan. 


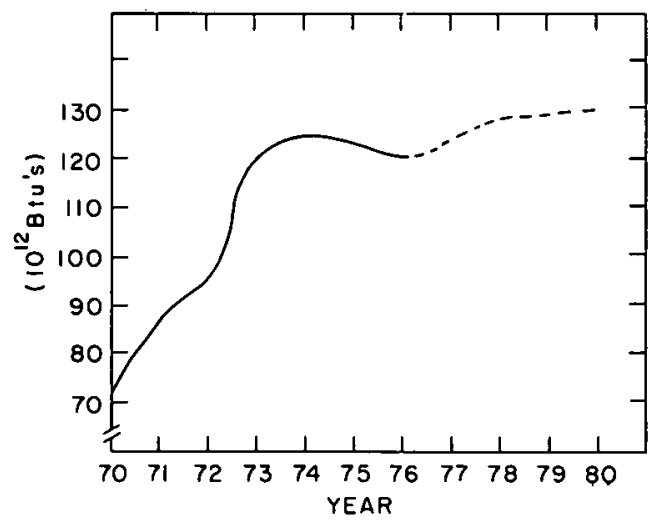

Figure 9. Total energy consumption in the Virgin Islands 1970-1975, and projected energy consumption 1976-1980.

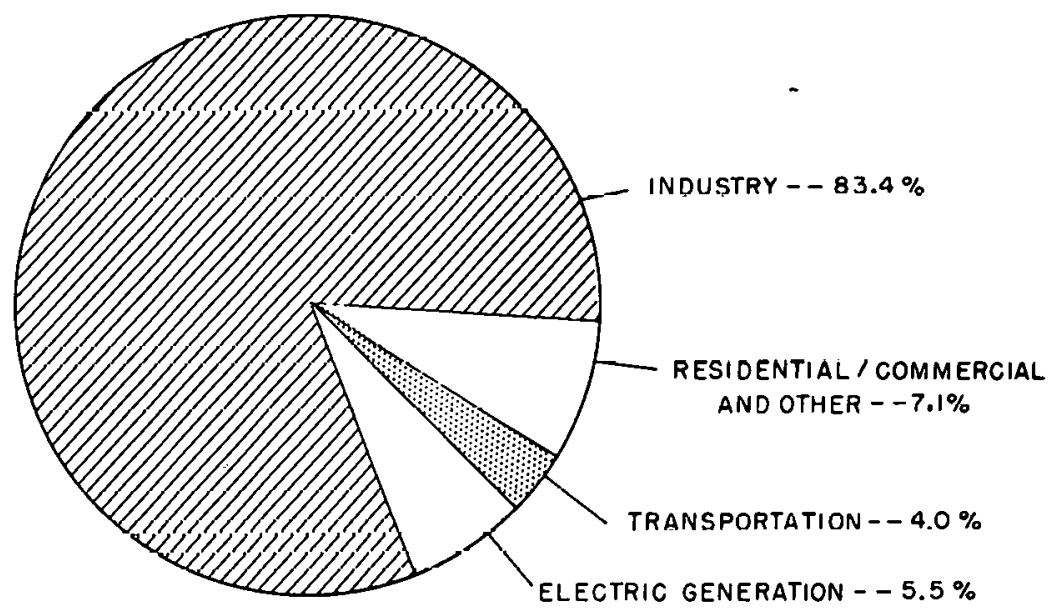

F1gure 10. Energy consumption by economic sector, 1975.

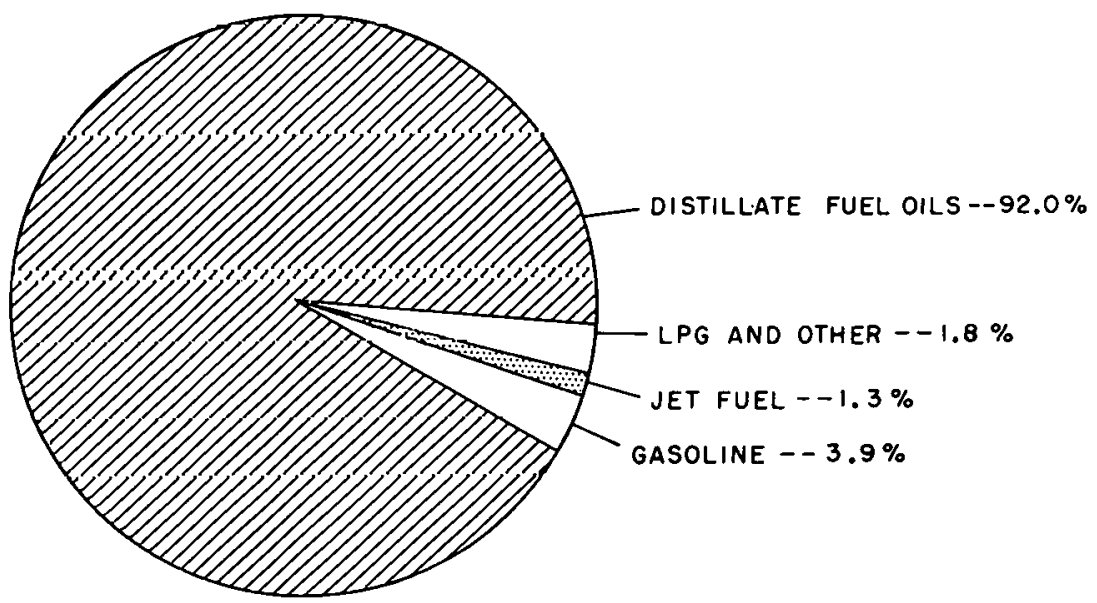

Figure 11. Fuel imports to the U.S. Virgin Islands, 1975. 
The Virgin Islands Gross Domestic Product, exclusive of the oil refinery, is estimated at approximately $\$ 430$ million. It has been roughly constant for the past three years due to diminished tourist activity resulting from the U.S. recession and an increase in the cost of flying to the Virgin Islands.

Average wages in the Virgin Islands are 65 to $75 \%$ of U.S. average. Mandated minimum wages are nearly at mainland levels (2.00-2.25 hr.), but mid-level positions are paid considerably less. Per capita personal income is $63 \%$ of U.S. average (1975 estimated).

Employment in energy related industries (o11 refinery and WAPA) equals approximately 2,000 of a labor force of 43,000. Another 300 to 500 workers are employed in the distribution and retail trade of petroleum products. Unemployment is not accurately known; reliable estimates for past five years are 1972-3\%; $1973-4.5 \% ; 1974-9 \% ; 1975-9 \% ; 1976-8 \%$. These are annual averages and do not reflect severe seasonal unemployment peaks, which are more severe and more profoundly felt during slack tourism seasons.

Few, if any employment effects can be directly traced to fuel curtailments. There is an immediate and current risk however that water curtailments, because of production problems at the Water and Power Authority, may result in reduced water supplies to hotels and resort services, which would result in reduced employment. 


\section{West Virginia*}

Energy Demand

Gross energy demand grew at an average rate of $4.8 \%$ from 1960 to 1970 and at 4\% per year from 1970 to 1975. From 1972 to 1975, consumption fell about $1 \%$ per year.

Energy consumption data, which includes estimates of fuels used for feedstocks, are shown in Table 63. Electricity consumption is omitted from the grand total entry in order to avold double counting since resources used to generate electricity are included.

The percentage of total consumption in each sector that was met by a particular fuel in 1975 is shown in Table 64. Table 65 shows the growth of electricity consumption in West Virginia over the past ten years.

TABLE 63

WEST VIRGINIA ENERGY CONSUMPTION In $1975^{1}$

$\left(10^{12} \mathrm{Btu}\right)$

\begin{tabular}{|c|c|c|c|c|c|c|c|}
\hline FUEL & RES. & com. & IND. & TRAN. & AGRIC. & UTITITY & TOTAL \\
\hline FT.ECTRICTTY & 16.6 & 10.0 & 31.2 & .0 & n & .0 & 57.8 \\
\hline PETROLEUM & 9.8 & 4.2 & 101.9 & 121.7 & 2.3 & 4.1 & 244.0 \\
\hline NAT. GAS & 52.9 & 25.6 & 68.9 & 14.5 & .0 & .4 & 162.3 \\
\hline COAL & 2.9 & 1.5 & 215.7 & .0 & .0 & 610.9 & 831.0 \\
\hline NUCLEAR & .0 & .0 & .0 & .0 & .0 & .0 & .0 \\
\hline HYDRO & .0 & .0 & .0 & .0 & $: 0$ & 4.9 & 4.9 \\
\hline TOTAL & 82.2 & 41.3 & 417.8 & 136.2 & 2.3 & 620.3 & 1242.3 * \\
\hline I'ER GAP. $\left(10^{6} \mathrm{Btu}\right)$ & $4 \dot{3} .6$ & 22.9 & 231.7 & 75.5 & 1.3 & 344.0 & 689.0 \\
\hline
\end{tabular}

*Electrictty omitted to avoid double counting. 
TABLE 64

DISTRIBUTION OF ENERGY CONSUMPTION FOR WV

(PERCENT)

\begin{tabular}{lrrrrrrr} 
FUEL & RES. & \multicolumn{1}{c}{ COM. } & IND. & TRAN. & AGRIC. & UTILITY & TOTAL * \\
ELECTRICITY & 20.2 & 24.2 & 7.5 & .0 & .0 & .0 & .0 \\
PETROLEUM & 11.9 & 10.2 & 24.4 & 89.4 & 100.0 & .7 & 19.6 \\
NAT. GAS & 64.4 & 61.9 & 16.5 & 10.6 & .0 & .1 & 13.1 \\
COAL & 3.5 & 3.7 & 51.6 & .0 & .0 & 98.5 & 66.9 \\
NUCLEAR & .0 & .0 & .0 & .0 & .0 & .0 & .0 \\
HYDRO & .0 & .0 & .0 & .0 & .0 & .8 & .4 \\
TOTAL & 100.0 & 100.0 & 100.0 & 100.0 & 100.0 & 100.0 & 100.0
\end{tabular}

*Electricity omitted to avoid double counting.

TABLE 65

CONSUMPTION OF ELECTRICITY: 1965-1974

(millions of kilowatt hours)

W. Va. U.S. W. Va. U.S.

Sector

Residential

Commercial

Industrial

TOTAL
Growth

2,442

1,356

2,186

5,978

747,355
Annual Growth Rate

$9.0 \% \quad 7.9 \%$

$8.3 \% \quad 7.7 \%$

$2.8 \%$

$5.3 \%$

$4.9 \%$

$6.6 \%$

\footnotetext{
* Some of the Information in this section comes from a report prepared for this briefing document by Patricia Rice of ORNL.
} 
Over $66 \%$ of the states energy demand in 1975 was met with coal as compared with the national average of about $18 \%$. Of the coal consumed, over $73 \%$ was used by utilities. Almost all the rest was used by industries. The transportation sector used about half of the petroleum consumed in the state. The industrial sector used about $42 \%$. Industries met more of their demand with natural gas than petroleum. Gas consumption in the industrial sector accounted for $42.5 \%$ of the total gas consumption. The residential sector used $33 \%$.

Demand for electricity grew at about 5.9\% per year from 1960 to 1970 and at 2.9\% per year from 1970 to 1975. Demand continued to rise from 1973 to 1975 at about $1.3 \%$ per year. Much of the electricity generated in West Virginia was exported. Of the $61.4 \times 10^{9} \mathrm{kwh}$ generated in $1975 \mathrm{in}$ West Virginia, only $16.9 \times 10^{9} \mathrm{kwh}$ were sold in the state. The mix of fuels used by utilities is shown in Table 66 .

TABLE 66

PERCENTAGE MIX OF FUELS USED BY ELECTRIC UTILITIES ${ }^{1}$

OIL GAS COAL NUCLEAR HYDRO

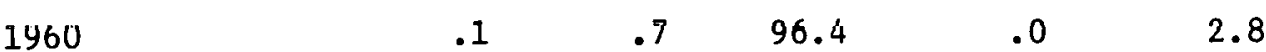

$\begin{array}{llllll}1970 & .8 & .2 & 97.7 & .0 & 1.4\end{array}$

$\begin{array}{llllllll}1975 & .7 & .1 & 98.5 & .5 & .0 & .8\end{array}$

Utilities used about $329 \%$ more coal in 1975 than they did in 1960. Energy Supply

Table 6.7 shows the 1975 resource and production estimates for energy resources extracted in West Virginia. 
TABLE 67

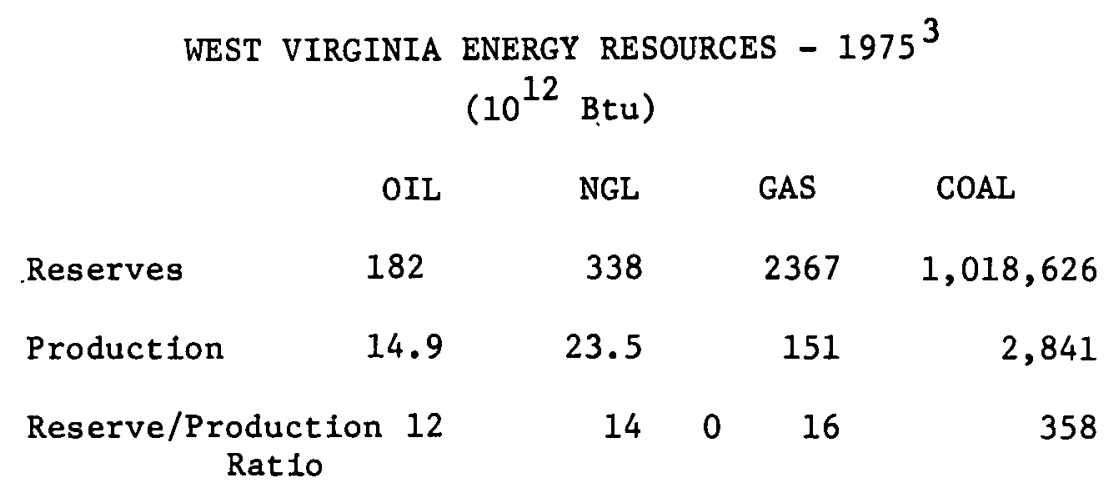

Over $35 \%$ of the coal has a sulfur content of less than $1 \%$. Another $35 \%$ has a sulfur content between 1 and $3 \%$. Coal is the economic lifeblood of West Virginia, directly employing approximately $10 \%$ of the work force in the state. Coal is mined in 34 of the 55 counties with output in 1975 of almost 110 million tons. The potential for coal--and therefore West Virginia--is bright given the growing national recognition that coal will be important in meeting our future energy needs.

\section{Prices}

Prices for selected fuels are shown in Table 68. Residential prices for gas were still below the national average in 1975 . Coal prices to utilities were about $18 \%$ above the national average.

\section{Other Data}

General economic, demographic, and climatic characteristics are shown in Table 69. Per capita income in West Virginia was about $82 \%$ of the national average. The unemployment rate was slightly lower than the national average ( 8.2 vs $8.5 \%)$.

While heating degree days were substantlally above normal this past winter, the change from the previous winter is particularly striking. In Huntington, heating degree days through March were $46 \%$ above their level for the previous winter. 
TABLE 68

A COMPARISON OF AVERAGE PRICESS PAID FOR

SELECTED ENERGY PRODLCTS ${ }^{4}$

WEST VIRGINTA

Fue1

oil

Residential - Retail

( $\$ / 100$ gallons)

Utility

$(\$ / \mathrm{Bb} 1)$

Gas

Residential

$$
\left(\$ / 10^{6} \mathrm{Btu}\right)
$$

Commercial

$$
\left(\mathrm{s} / 10^{6} \mathrm{Btu}\right)
$$

Industrial

$$
\left(\$ / 10^{6} \mathrm{Btu}\right)
$$

Utility

(c/McF)

Sna

- Utility

$$
\text { ( } \$ / \text { ton) }
$$

Gasoline - Regular

(c/gallon)

Electricity

Total Utility Fossil Fuel Costs (c/Kwh)

$$
.34
$$

.93

$174 \%$

Residential

( $c /$ Kwh)

2.32

3.27

$41 \%$

Commercial and Industrial

Small ( $c /$ Kwh)

Large ( $c /$ Kwh)

Total Sales

(c/Kwh)
$-2.12 \quad 3.13$

$48 \%$

$1.05 \quad 2.08$

$98 \%$

$1.54 \quad 2.61$

$69 \%$ 


\section{United States}

Tables similar to those presented for the states and the District of Columbia are given below so that comparisons with national averages can be made.

Gross energy consumption in the U.S. grew at an average rate of $4.8 \%$ per year from 1960 to 1970, and at about 1\% per year from 1970 to 1975. From 1973 to 1975 consumption has declined at about 2\% per year. Energy consumption data is shown in Table 70 . The percentage of total consumption in each sector that was met by a particular fuel in 1975 is shown in Table 71. The mix of fuels used by utilities is shown in Table 72 .

TABLE 70

UNITED STATES ENERGY CONSUMPTION IN $1975^{1}$

$$
\left(10^{12} \mathrm{Btu}\right)
$$

FUEL

ELECTRICITY

PETROLEUM

NAT. GAS

COAL

NUCLEAR

HYDRO

TOTAL
RES. COM. IND.

$$
1999.9
$$$$
2796.9
$$$$
5081.7
$$

81.2

.0

.0

9959.7

1641.3

$$
2109.7
$$

2257.2

6801.8

2588.7

8885.9

43.7

3634.2

$$
.0
$$

.0

$6383.4 \quad 21599.1$
TRAN.

$$
14.6
$$

17170.7

601.6

.0

.0

.0

17786.9

46.7

83.5

3.0

96.9

333.7

*Electriclty omitied to avold double counting. 
TABLE 71

DISTRIBUTION OF ENERGY CONSUMPTION FOR UNITED STATES

(PERCENT)

$\begin{array}{lrrrrrrr}\text { FUEL } & \text { RES. } & \text { COM. } & \text { IND. } & \text { TRAN. } & \text { AGRIC. } & \text { UTIITTY } & \text { TOTAL } \\ \text { ELECTRICITY } & 20.1 & 25.7 & 10.5 & .1 & .0 & .0 & .0 \\ \text { PETROLEUM } & 28.1 & 33.0 & 31.5 & 96.5 & 100.0 & 15.7 & 46.1 \\ \text { NAT. GAS } & 51.0 & 40.6 & 41.1 & 3.4 & .0 & 15.7 & 28.7 \\ \text { COAL } & .8 & .7 & 16.9 & .0 & .0 & 44.8 & 18.3 \\ \text { NUCLEAR } & .0 & .0 & .0 & .0 & .0 & 8.7 & 2.5 \\ \text { HYDRO } & .0 & .0 & .0 & .0 & .0 & 15.1 & 4.4 \\ \text { TOTAL } & 100.0 & 100.0 & 100.0 & 100.0 & 100.0 & 100.0 & 100.0\end{array}$

$\star_{E}$ lectricity omitted to avold double counting.

TABLE 72

PERCENTAGE MIX OF FUELS USED BY ELECTRIC UTILITIES ${ }^{1}$

OIL GAS COAL NUCLEAR HYDRO

$\begin{array}{llllll}1960 & 7.0 & 22.2 & 51.9 & .0 & 18.9\end{array}$

$\begin{array}{llllll}1970 & 12.9 & 24.5 & 45.4 & 1.4 & 15.8\end{array}$

$\begin{array}{llllll}1975 & 15.7 & 15.7 & 44.8 & 8.7 & 15.1\end{array}$

Demand for electricity grew at $7.4 \%$ per year from 1960 to 1970 and $4.5 \%$ per year from 1970 to 1975. From 1973 to 1975 demand has grown at about . $8 \%$ per year.

Price data is shown in Table 73 and general economic and demographic data is shown in Table 74 . 
TABLE 73

A CONIPARISON OF AVERAGE PRICES PAID FOR

SELECTED ENERGY PRODUCTS ${ }^{4}$

UNITED STATES

Fue1

1972

1975

Percent Increase

oi1

Residential - Retail

( $\$ / 100$ gallons)

$19.79 \quad 41.43$

$109 \%$

Utility

$(\$ / B b 1)$

3.78 .12 .24

$224 \%$

Gas

Residential

$\left(\$ / 10^{6} \mathrm{BCu}\right)$

$1.19 \quad 1.69$

$42 \%$

Commercial

$$
\left(\mathrm{s} / 10^{6} \mathrm{Btu}\right)
$$

1.38

$52 \%$

Industrial

$$
\left(\$ / 10^{6} \mathrm{Btu}\right)
$$

.99

$120 \%$

Utility

(C/ḾCF)

31.9

77

$141 \%$

Coal - Utility
( $\$ /$ ton)
$8.69 \quad 18.71$
$115 \%$

Gasoline - Regular

$$
\text { (c/ga11on) }
$$

$36.13 \quad 57.22$

$58 \%$

Elecuricity

l'otal Utility Fossil Fuel Costs

$$
\text { (a/Kwh) }
$$

1.12

$16 U \%$

Residential
(c/kvh)
2.29
3.21
$10 \%$

Commercial and Industrial

$$
\begin{gathered}
\text { Sma11 ( } c / K w h) \\
\text { Large ( } c / K w h) \\
\text { Total Sales } \\
(c / K w h)
\end{gathered}
$$

$2.22 \quad 3.23$

$45 \%$

1.09

1.92

$76 \%$

$1.77 \quad 2.70$

$53 \%$

Consumer Price Index

U.S. SMSA Average

$125.3 \quad 161.2$

$29 \%$ 


\section{TABLE 74}

GENERAL ECONOHIC AND DEMOGRAPHIC CHARACTERISTICS

OF UNITED STATES IN $1975^{6}$

Population (thousands)

Land Area $\left(10^{3}\right.$ Square Mile)

Population Per Square Mile

Labor Force (Thousands)

Employment (Thousands)

Unemployment Rate (\%)

Personal Income $\left(10^{9}-1.975\right.$ Dollars $)$

Per Capita Income (1.975 Dollars)
213,121

3,534

60.3

94,793

84,783

8.5

$1,243.3$

5,834 
References and Notes

1. FEA $1 / 28 / 77$ Strawman data were the principal source of energy consumption data. Coal consumption figures were revised using FEA 3/25/77 data. Feedstocks of oil of $3413 \times 10^{12}$ Btu for the US in 1975 were added by distributing this amount across states in proportion to total personal income in 1975 in "Chemicals and Allied Products" as reported in Survey of Current Business, U.S. Dept. of Commerce, Bureau of Economic Analysis, Vol. 56, No. 8, August 1975, pp. 18-25. Asphalt and Road Dil were moved from the commercial to the industrial sector. Population data were taken from Statistical Abstract of the I.S., Bureau of Census and Dept. of Commerce, 97th edition, Dec. 1976, Table 10, p.11.

2. Statistical Abstract, Table 725, p. 449.

-3. Oil, natural gas liquids (NGL), and natural gas date were taken from Gas Facts, 1975 Data, American Gas Association, Tables 2, 3, and 7.

Coal data were taken from "Coal-Bituminous and Lignite in 1975", Division of Fuels and Data and Division of Coal, U.S. Dept. of Interior, Feb. 10, 1977. Reservye data were adjusted for production in 1974 and 1975. We assumed that reserves were reduced by 2 times the production level for underground production and 1.25 times for surface production. Reserve data for Pennsylvania were assumed to include estimates of anthracite. Anthracite production figures were obtained from L. W. Westerstrom, 202-634-1033, $\Lambda$ pri1 1977.

4. Fuel costs for electric utilities (oil, gas, coal, and total) were taken from the 1972 and 1975 Edison Electric Institute Statistical Yearbook of the Electric Utility Industry, Table 435. Prices for electricity sold to all sectors were calculated from Tables 225 and 365 .

Residential oil prices were taken from "Retail Prices and Indexes of Fuels and Utilities-Residential Usage", U.S. Dept. of Labor, Bureau of Labor Statistics, and from personal communication with M. Witcomb, 202-523-9621, Apri1 1977.

Natural gas prices, except for utilities, were taken from Gas Facts, 1975 Dala, Table 93, p. 112, and frum persunal communlcatlon wich Robert Barlow, April, 1977.

Gasoline prices shown are retail with tax. The 1975 data were ohtained from personal communication with $\mathrm{Mr}$. Lighter at the American Petroleum Institute, Washington, DC, April 1977, and the 1972 data were from Mr. Wager at Platts, New York City, April 1977.

Consumer price index for selected cities or SMSAs were taken from Statistical Abstract, Table 710, p.441. 
5. Per capita income (in current dollars) was taken from Statistical Abstract, Table 664, p. 402. Unemployment dates were taken from Statistical Abstract, Table 583, p. 362.

6. The following data were taken from the Statistical Abstract:

Population - Table 10, p. 11

Land Area - Table 303, p. 180

Labor Force calculated from Table 583, p. 362

Employment - Table 583, p. 362

Unemployment Rate - Table 583, p. 362

Personal Income - Table 643, p. 401

Per Capita Income - Table 644, p. 402

Heating degree day data was obtained from "Weekly Weather and Crop Bulletin", U.S. Dept. of Commerce and U.S. Dept. of Agriculture, Vol 64, No. 13, March 29, 1977, p. 10, and subsequent issues for revisions purposes. 
Chapter IV Environmental Quality and Concerns*

Most environmental concerns related to energy in the region are similar to those found in other parts of the country. They include water pollution and land destruction caused by coal mining, alr pollution from fossil fuel burning, thermal discharges from power plants, radiation from nuclear power plants, destruction of wildlife habitats from large scale energy projects, air and water pollution from oll refineries and other petrochemical facilities, and spills from the drilling and transportation of petroleum products.

Because a large portion of the Regton is densely populated and highly industrialized both air and water quality are below standard in much of the Region. While significant gains have been made in the last few years, energy development without proper regard for the environment could wipe out what progress has been made.

Water quality is still poor in much of the Region. Energy related development's greatest impact will be in the area of thermal discharges from power plants. Rivers in or near the major metropolitan areas are already lined with many power plants. EPA regulations virtually require closed cycle cooling (cooling towers) on new power plants. There is a serious question as to whether rivers near large cities can handle new power plants and the enormous amounts of water which cooling towers require. This is less of a problem in the more rural areas of the Region but must st1ll be considered as a mafor constraint.

Coal mining can also have an adverse impact on water quality. However, the present national permit program on wastewater discharges (NPDES) could keep these to an acceptable level. Strict deep and strip mining laws passed by the states (Table 75) should provide for improved rerlamation and Foderal legislation is expected this year.

Hydroelectric power projects, especially pumped-storage facilities, have the potential to degrade water quality in rivers and streams. New routes for transmission lines and pipelines take land out of productive or recreational use. The coastal or estuarine siting of power plants and *Major portions of this chapter were contributed by Eric Outwater (Reg, II) and Michael J. Chern (Reg. III) of the Reglonal EPA Offices. 
TABLE 75

STATE SURFACE MINED AREA RECLAMATION PROGRAM (December 1975)

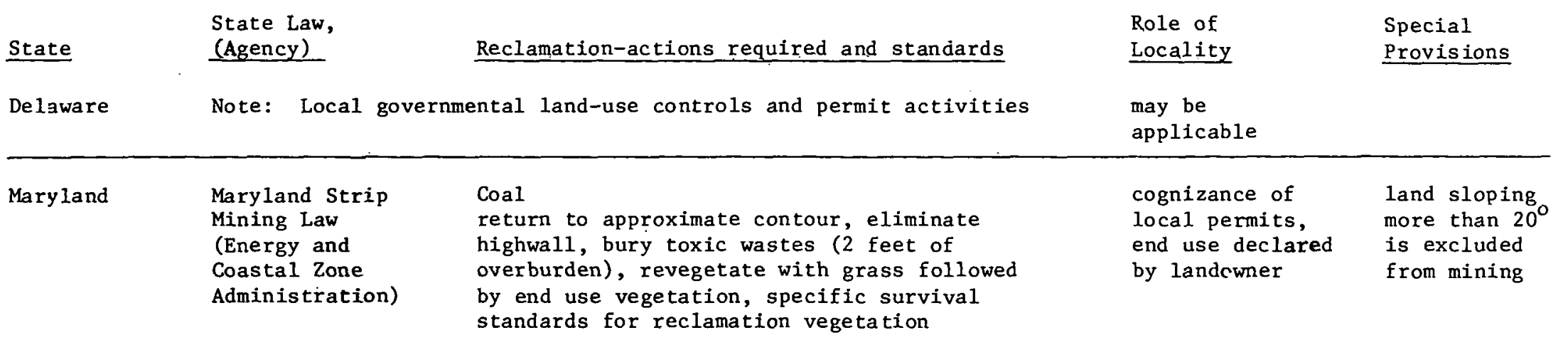

New Jersey Note: Local governmental land-use controls and permit activities

\begin{tabular}{|c|c|c|c|c|}
\hline New York & $\begin{array}{l}\text { New York State } \\
\text { Mined Land Re- } \\
\text { clamation Law } \\
\text { (Dept. of En- } \\
\text { vironmental } \\
\text { Conservation) }\end{array}$ & $\begin{array}{l}\text { covers all minerals and mined topsoil, } \\
\text { highwall and pitwall reduction to be } \\
\text { compatible with surrounding terrain, } \\
\text { mining from submarine lands covered by } \\
\text { another act }\end{array}$ & $\begin{array}{l}\text { local mining } \\
\text { laws and con- } \\
\text { trols stricter } \\
\text { than the Act } \\
\text { prevail (local } \\
\text { enforcement }\end{array}$ & \\
\hline Ohio & $\begin{array}{l}\text { (1) Strip Mine } \\
\text { law and ( } 2) \\
\text { Surface Mine } \\
\text { Law (Dept. of } \\
\text { Natural Resources) }\end{array}$ & $\begin{array}{l}\text { (1) Coal and (2) all other minerals, } \\
\text { topography reclamed to approximate } \\
\text { original contour }\end{array}$ & & $\begin{array}{l}\text { (1) conveys } \\
\text { authority to } \\
\text { delete certain } \\
\text { lands from } \\
\text { surface mining } \\
\text { (2) plan covers } \\
10 \text { year period } \\
\text { (1) applicant } \\
\text { provides } \\
\text { estimate of } \\
\text { reclamation } \\
\text { costs. }\end{array}$ \\
\hline
\end{tabular}


STATE SURFACE MINED AREA RECLAMATION PROGRAM (cont'd) December 1975)

\begin{tabular}{|c|c|c|c|c|}
\hline State & $\begin{array}{l}\text { State LEW, } \\
\text { (Authority) } \\
\end{array}$ & Re:lamation-Actions Required and Standards & $\begin{array}{l}\text { Role of } \\
\text { Loca-ity } \\
\end{array}$ & $\begin{array}{l}\text { Special } \\
\text { Provisions } \\
\end{array}$ \\
\hline Pennsylvania & $\begin{array}{l}\text { Surface mining } \\
\text { Conserva=ion } \\
\text { and Reclamation } \\
\text { Act, as amended } \\
\text { (Dept. c: } \\
\text { Environmental } \\
\text { Resources) }\end{array}$ & $\begin{array}{l}\text { All minerals, Approximate original contour- } \\
\text { terrace; or, serve appropriate end-use, } \\
\text { Eliminate iighwall }\end{array}$ & & $\begin{array}{l}\text { Applicants } \\
\text { provides } \\
\text { detailed } \\
\text { estimate of } \\
\text { reclamation. }\end{array}$ \\
\hline Virginia & $\begin{array}{l}1-45.1-198 \text { and } \\
2-\text { Title } 45.1- \\
180 \text { chap. } 16 . \\
\text { (Dept. a }=\text { Con- } \\
\text { servation and } \\
\text { Economic Dev.) }\end{array}$ & $\begin{array}{l}\text { (1) coal and (2) all other minerals, backfill } \\
\text { and grad tc "retain spoil on bunch insofar as } \\
\text { feasible", reduce highwall or pitwall "to the } \\
\text { maximum extent practizable", bury toxic wastes } \\
\text { with } 4 \mathrm{ft} \text {. of material suitable for plant growth, } \\
\text { sets standards for acoess across highwall }\end{array}$ & $\begin{array}{l}\text { local soil } \\
\text { and water } \\
\text { conservation } \\
\text { districts } \\
\text { advise }\end{array}$ & \\
\hline \multicolumn{5}{|l|}{ West } \\
\hline Virginia & $\begin{array}{l}\text { Art. } 6, \text { Chapter } \\
20, \text { Code of West } \\
\text { Virginia, as } \\
\text { amended idept. } \\
\text { of Natural } \\
\text { Resources) }\end{array}$ & $\begin{array}{l}\text { ali minera-s, jrading and backfill rules } \\
\text { vary by area mining or contour mining, contour } \\
\text { mined areas will be slitable for farm machinery, } \\
\text { tozic materials buries to } 4 \text { ft. with material } \\
\text { suitable for plant growth, revegetation } \\
\text { standards, bazifill s andards }\end{array}$ & & \\
\hline
\end{tabular}

(From: A Guide to State Programs for the Reclamation of Surface Mined Areas, USGS-C 731-1976) 
subsequent thermal effluents poses special problems for those highly

productive areas. Such problems are being confronted more frequently in the region as the development of energy facilities progresses.

To protect the environment while not prohibiting development the states are involved in a variety of planning and regulatory activities. Each state in the region regulates (through legislation or executive agency regulations) the use and development of wetlands and most are participating (with.localities) in the HUD flood plain insurance program. All Atlantic coast states (as well as Ohio, Puerto Rico and the Virgin Islands) are participating in the Department of Commerce Coastal Zone Management Program. While no state in the region has developed a land use policy backed by comprehensive regulations many have initiated the basic inventory effort which, in several cases, includes the designation of critical areas in which development will be prohibited.

\section{Delaware}

Air quality in Delaware is relatively good. Only the northern part of the State near Wilmington (considered part of the Philadelphia metropolitan area) is not attaining standards for particulates and $\mathrm{SO}_{2} \cdot$ Like the rest of the region, however, the entire state is considered non-attainment for oxidants.

Water quality is also relatively good. Only the Delaware River fails to meet standards and most of its pollution is produced upstream in Pennsylvania. Delaware has a very strict Coastal zone law which restricts industrial growth which could degrade the natural environment. This law could have some impact on proposed offshore supertanker ports in the Delaware Bay.

There are presently no nuclear power plants in Delaware. A plant had been proposed for Summit, but the reactor manufacturer was unable to meet his commitments and the project was halted although the utility may ask relicensing of the facility using a different type of reactor.

Delmarva Power and Light is planning to build a new coal fired 400 Mwe plant near Millsboro, Del. This plant has already been approved by EPA under their PSD regulations, 
Under the Energy Supply and Environmental Coordination Act, the Federal Energy Administration (FEA) ordered Delmarva's Edge Moor Station to convert from oil to coal firing. EPA has completed its review and certifled the plant for conversion with the installation of particulate controls. FEA has not yet issued a final conversion order.

Maryland

Air quality in Maryland is mixed. The entire state is well within standards for $\mathrm{SO}_{2}$, but the Baltimore, Cumberland, Washington, and Central Maryland areas fail to meet particulate standards. Again, the entire state is considered nonattainment for oxidants.

Water quality in Maryland is fairly good with only sections of the Potomac, Patuxent, Patapsco and Back Rivers of major concern. Most of these water quality problems are due to urbanization except for the extreme upper portion of the Potomac. which is in the coal mining area of the state.

There is one nuclear power station in Maryland at Calvert Cliffs. Another at Douglas Point is starting licensing hearings. EPA has not started any review of the project. It is interesting to note that both these plants are located on the Chesapeake Bay. With the water supply problems evident on many rivers, the Chesapeake will probably be considered for more power plants in the future. The Federal Coastal Zone Management Program has among its goals the designation of potential sites for power plants, and therefore will have some impact on energy, both in Maryland and in Virginia.

FEA has ordered conversion to coal firing at Baltimore Gas and Electric's Crane, Wagner and Riverside Stations and also Potomac Electric Power's Morgantown Station in Newburg. EPA certified all plants for conversion if particulate controls are installed or upgraded. No final conversion order has been issued by FEA.

New Jersey

One of the main causes of water quality problems in New Jersey is the heavy discharge of organic, oxygen depleting wastes. Characteristic of these discharges, the receiving waters are plagued with low concentrations of dissolved oxygen, high BOD and high bacterial counts. These discharges impalr recreational use of the water by limiting fish populations and by prohibiting human contact. 
The overall water quality of New Jersey varies in different parts of the state. Earlier attempts to evaluate water quality have been hindered by a weak data base. The Federal Water Pollution Control Act Amendments of 1972 requires a state-wide water quality assessment. An improved surveillance network should provide for a better evaluation of trends in 1977. Previous reports have, however, provided several observations.

The urban section of the Northeast Metropolitan area has shown overall signs of poor water quality. The area is characterized by fully developed dense urban and industrial land use. Sections subject to heavy loads from urban runoff and combined sewer overflows during storm conditions show depressed levels of dissolved oxygen concentrations. Other areas, such as the tidal Hackensack Bașin, are anticipated to show increases in dissolved oxygen concentrations as point source discharges are upgraded and improved sanitary landfill control measures are implemented.

In the Raritan River Basin the water quality has been described as good for most industrial domestic and recreational uses. However, there are localized low dissolved oxygen concentration and high fecal coliform concentrations, which may be caused by point source discharges.

For most of the length of the mainstem of the Delaware, the water quality is good. However, water quality in the. Delaware. River Estuary porttion. of the main stem is serlously degraded due to the impact of municipal and industrial waste discharged as the river passes the Trenton, Camden, and Wilmington metropolitan areas. Current discharges in this area are subject to a waste load allocation program which is upgrading this reach to meet water quality standards and to preserve the existing quality where it is currently satisfactory.

The quality of New Jersey's alr has been generally improving. Alr quality improvement trends are evident throughout the state. However, major portions of the area are still experiencing non-attainment of the National Ambient Air Quality Standards: 
Pollutant

Particulate Matter

Sulfur Oxides

Hydrocarbon/Oxidants

Carbon Monoxide

Nitrogen Oxides

*There are four (4) such regions in the state.
\# Air Quality Control Regions Not Achieving NAAQS*

2

0

4

4

1

New York

The quality of New York's waters has been improving measurably. Even as of 1975 less thatn 685 miles of the 7400 miles of stream directly affected by pollution discharges were affected to the degree that use has been impaired.

Water quality improvement trends are evident throughout New York State as indicated by the increase in the National Science Foundation water quality index over a five year period ending in 1974. As a result of efforts over the five years, all but one of the basin segments where data are collected are now in the medium-good range as defined by this water quality index.

In 1976 a New York State report examined the "biological health" of several major waterways. It was shown that major degradation of benthic community structures was associated with the high impact point sources of pollution in urban-industrialized areas. Fortunately, the water quality index of these waters has indicated an improvement response to the billions of local, state and federal construction dollars being expended for capital and operating costs for treatment facilities.

Recent water quality problems in New York State have focused on toxic substances, particularly PCB's. A statewide PCB survey during the summer of 1975 has shown "hot spots" where fish flesh levels exceeded that considered safe for human consumption by the USFDA in several New York rivers. The state has implemented a program to detect discharges of these toxic materials. The plan is to be integrated into an EPA region-wide strategy to deal with such present and future problems.

The quality of New York's air has been generally improving. Air quality improvement trends are evident throughout the state. However, major portions of the area are still experiencing non-attainment of the National Ambient Air Quality Standards: 
$\underline{\text { Pollutant }}$

Particulate Matter

Su1phur Oxides

Hydrocarbon/Oxidants

Carbon Moxoxide

Nitrogen Oxides

*There are eight (8) such regions in the state.
\# Air Quality Control Regions Not Achieving NAAQS*

\section{5}

5

8

3

1

\section{Pennsylvania}

Many areas of Pennsylvania do not meet particulate standards, while the entire state does not meet photochemical oxidant standards. Only the Philadelphia and Pittsburgh areas fail to meet $\mathrm{SO}_{2}$ standards. This means that many new fossil fuel power plants and any petroleum product facilities planned for the state would come under EPA's new offset policy. Briefly this policy requires that the emissions produced by any new facility built in a non-attainment area must be more than offset by a reduction in emissions from existing sources. In addition, any new stationary source of either particulates or $\mathrm{SO}_{2}$ must also be reviewed and approved under EPA's Prevention of Significant Deterioration (PSD) regulations unless the source comes under the offset policy. PSD regulations require the facility to be equipped with pollution control equipment of the best available technology and that emissions from the new source will not increase ambient levels of pollution beyond an approved increment.

Water quality in Pennsylvania is improving but still poor in many areas. Large portions of the Delaware, Susquehanna, and Ohio River Basins either consistently fall to meet water quality standards or occassionally fail to meet standards. A good deal of the problem is connected with water pollution from coal mining. While much of pollution from mining comes from abandoned mines which cannot be controlled under present law, the mere fact of its existence makes resistence to new mining strong among environmentalists. They fear that new mines will increase the problem despite federal and state controls.

No new nuclear power plants have been proposed for Pennsylvania, although several fossil fuel plants are in the early planning stage. Energy parks, combining several auclear and fossil fuel plants in one location, are undergoing feasihility planning. Four nuclear units are now on line at three locations, 
with six new units at four locations under construction. The Limerick stations, north of Philadelphia, may have.some water supply problems. The Station was counting on water being diverted to the Schuylkill River from the Tocks Island Dam on the Delaware River. The Tocks project is now in limbo and will probably not be built. Limerick officials are hoping that several alternatives to Tocks now being considered will be able to provide the water.

The Tocks Island Dam, although primarily considered to be a water supply and flood control profect, would also have provided hydroelectric power. Other controversial hydro projects are the Muddy Run and Stone Creek Pumped Storage projects on tributaries of the Susquehanna. Muddy Run is already operating, with Stone creek proposed.

Another major energy project is the proposed TRANSCo facility in Delaware County. The facility would convert naptha into a synthetic natural gas. Although the project is being fought by some citizens mainly on safety considerations, there are some environmental problems. The plant must undergo PSD review for particulates and $\mathrm{SO}_{2}$ and meet EPA's offset policy for hydrocarbons.

Virginia

Air quality in Viginia is also mixed. The entire stace easily meets $\mathrm{SO}_{2}$ standards, but the Washington, Richmond, and Valley of Virginia areas do not meet particulate standards. The entire state exceeds standards for oxidanes.

Water quality is good through most of the state, except for the highly urbanized east. Major portions of the James, York, Rappahannock and Potomac Rivers do not meet water quality standirds.

There are two nuclear power stations in Virginia. Two units at Surrey are in operation, with two other units under indefinite postponment. The other facility is at North Anna. This facility was strongly opposed by environmental groups because it.was claimed the site was located on a fault line. Nevertheless, the first unit should be on line this year.

FEA has ordered Virginia Electric Power's Chesterfield, Portṣmouth and Yurktuwn Stacions to switch to coal. EPA has certified these stations for conversion if particulate controls are installed. The Yorktown Station, however, is still under a county court ruling requiring it to burn oil. This situation has yet to be worked out by FEA, nor have final conversion orders been issued to any of the facilities. 
The proposed Hampton Roads Energy Company refinery in Portsmouth is one of the most controversial energy issues in the state. Environmentalists have fought the refinery on both air and water pollution grounds. It must pass both PSD review and EPA's offset policy before it can be built. The Commonwealth of Virginia has issued an NPDES permit for wastewater discharges from the refinery, and EPA's review Indicated the proposed discharge should have little if any effect on water quality.

Several highly controversial pumped storage projects have also been proposed in Virginia. Still under consideration are Bath County, Davis, and Randolf. The proposed Blue Ridge pumped storage facility on the New River is apparently dead due to intense pressure by environmentalists and some segments of the press.

\section{West Virginia}

West Virginia's alr quality is also mixed. Particulate standards are not being met in the Welrton-Wheeling, Kanawha Valley, Central and North Central parts of the state. Only the Weirton-Wheeling area does not meet $\mathrm{SO}_{2}$ standards, although the entire state does not meet oxidant standards.

Water quality is poor in many areas, although it is much improved over several years ago. Major stretches of the Ohio, Monongahela, Kanawha, and Little Kanawha Rivers do not meet water quality standards. Most of the pollution is due to elther coal mining or industrial discharges.

There are no nucleap power plants in. West Mirginta and none planned. The reason is coal. Coal is at the root of most environmental-energy issues in the state today. West Virginia has strict regulations on the sulfur content of coal that can be burned in power plants. Just recently Ohio passed regulations that would allow some power plants in Ohio to burn higher sulfur coal than those in West Virginia. A good deal of coal mined in West Virginia cannot be burned there because of 1ts high sulfur content. West Virginia's past Governor Arch Moore ordered the state not to enforce its $\mathrm{SO}_{2}$ regulations because of this situation. He claimed that West Virginia miners were out of work and that it was unfair to allow power plants on the Ohio side of Ohio River to burn coal with a higher sulfur content than those on the West Virginia side. Moore ordered the State Air Pollution Control Commission to do new modeling studies of all West Virginia power plants to determine if the state $\mathrm{SO}_{2}$ 
standards could be relaxed. EPA is also remodeling all $\mathrm{SO}_{2}$ sources in the Ohio Valley. Several other modeling studies have either been done or requested for $\mathrm{SO}_{2}$ sources in the state. This issue is far from resolved, and its outcome will be most important to the energy picture in West Virginia.

The requirement to do a National Environmental Policy Act (NEPA) review on NPDES permits issued to new coal mines could have a delaying effect on the opening of new mines in the state. EPA is working on ways to insure that NEPA reviews can be expedited, but it is hard to estimate what the actual effect will be until the EPA issues discharge guidelines for new coal mines, which is expected shortly.

Puerto Rico

While Puerto Rico lacks an extensive level of historical air quality data, the Environmental Quality Board of Puerto Rico, in conjunction with the Environmental Protection Agency has completed an investigation of present (1974-1975) and future (1978-1955) air pollution levels for 12 designated AQMAs in Puerto Rico using the EPA's air quality display model to predict particulate and sulfur dioxide concentration levels for the entire island. The results of the predicted base year air quality showed that only the San Juan AQMA excepded Federal Air Quality Stanlaids for particulate matter and none of the AQMAs exceeded the standards for $\mathrm{SO}_{2}$. Direct measurements for short-term averaging periods ( 3 hour and 24-hour) were exceeded.

In gum, the icuultg of the experiment to date have shown that present air quality in certain areas of the island was well above ambient standards and expected to worsen and spread. It has been recommended that an air quality maintenance plan to include balancing island-wide activities and changes in emissions regulations be developed.

Puerto Rico lacks an extensive record of historical water quality data. The U.S. Geological Survey, however, maintains a routine monitoring network of some surface waters which provides data for evaluation.

The general trends noted in the surface waters over the last two years Indicate that there has been some improvements in water quality with respect to dissolved oxygen and coliform bacteria. This improvement is attributed to both the sewering of rural areas, the construction of new treatment facilities, and the addition of adequate chlorination facilities at the existing plants. Many monftoring stations, however, still show a contravention of water quality standards. 


\section{Virgin Islands}

Ecologically, small tropical islands may be one of the most fragile of systems. Negative impacts often have irreversible affects. The entire south shore of St. Croix west (i.e., downwind and downcurrent) of the refinery and alumina smelter is destroyed for any future recreation or tourism use. The reef is dead leading to eventual shoreline destruction. To cope with development while protecting fragile systems the Islands are participating in the Coastal Zone Management Program designed to provide clear guidelines for the orderly development and perservation of all coastal areas.

Water quality in the Virgin Islands varies between the three islands of St. Thomas, St. John, and St. Croix. All of the waters, however, have been described as being in compliance with water quality standards by the Virgin Islands Conservation and Cultural Affairs Department. In St. Thomas the construction of the Charlotte Amalie Sewerage System has removed two and a half million gallons per day of raw sewage from the waters of the harbor and produced significant water quality improvements over the last five years.

The greatest increase in water quality has occurred along the south shore of St. Croix. The area in the past had been affected by dredging activities for development and maintenance of shipping channels providing access to major industrial facilities on the island. The water quality data now shows that average levels are approximately equal to average values observed in clean waters elsewhere.

In St. John the water quality that has been characterized as "excellent" has been maintained.

The air quality of the Virgin Islands is meeting National Ambient Air Quality Standards, with the exception of a localized problem in the industrial complex on St. Crolx (for sulfur dloxide). 


\section{CHAPTER V}

\section{ENERGY ISSUES AND ACTIONS}

Four major factors, two related to problems of supply and use in the region and two related to energy planning and management, have interacted to bring energy affairs into the public and political arena to the greatest extent since the OPEC embargo.

First, the severity of the past winter precipitated problems which put tremendous burdens on all levels of government. Critical, though perhaps transitory damage from storm and ice conditions, prolonged cold temperatures, and fuel shortages resulted in major disaster or emergency declarations for 69 counties in Ohiu, New Yurk, Pennsylvania, New Jersey, Maryland and Virginia. Requests for disaster declarations for an additional 65 counties were denied. This was followed early in the spring by flood and storm conditions which initlated action resulting in disaster declarations for parts of Virginia and West Virginia (a similar petition by Gov. Carey for 11 counties in New York was denied).

Estimates of the impacts of the winter are difficult to obtain and substantiate, however, a principal factor in the requests for emergency and disaster assistance was the economic losses to government, business and industry. Lost work time, the diversion of resnurses from regular to emergency duties, the curtailment or shifting of fuel supplies, overtime, storm damage to facilities, and increased demand for people-oriented emergency services placed direct and indirect economic burdens on government, business and industry. Unemployment in the region approached two million persons, implying an increase of four to five times the pre-winter rate. Estimates of direct damage costs resource losses, and unbudgeted obligations to the states range from $\$ 400-\$ 800$ million.

Second, on July 13, 1977, a series of events occurred which caused a total loss of electric power to the Consolidated Edison Company, an area of approximately 593 square miles with a population of 8.7 million people. In the period required for complete restoration of service (approximately 25 hours) reports of the failure of service systems, massive.looting and vandalism, the loss of commercial revenue, and the costs of providing emergency services drew national attention to the trauma of New York City. 
In the weeks that followed record temperatures and record demand for electricity gave rise to concern that similar system failures could be repeated elsewhere. Utility officials, citing the unique series of events leading to Con Ed's problem, including sequential lightning strikes which Isolated the system from 1ts pool suppliers, and the reliability of electric interconnections, hastened to affirm that such system failures could not be repeated elsewhere.

Third, at the end of April President Carter outlined to the nation the National Energy Program developed by Dr. Schlesinger and his staff*. The contents of this program, its manner of unveiling, the reaction of industrial, political and public interest concerns, and the relationship of specific components of the program to existing legislation and policy have kept the Program in the limelight.

And lastly, each state in the region has submitted a Comprehensive Energy Conservation Plan to the Federal Energy Administration pursuant to the Energy Policy and Conservation Act (EPCA). Each plan contains flve mandatory conservation elements required by the FEA (mandatory lighting efficiency standards for public bulldings; carpool, vanpool and public transportation programs; energy efficiency standards and policies to govern procurement practices of the state and its political subdivisions; thermal efficiency and insulation requirements for public buildings; and a traffic law permitting right turn on red lights) and supplemental elements considered appropriate by the agency developing the plan. To be approved, and eligible for federal implementation funds, the Plan must be consistent with FEA guidelines and provide for an overall 5\% reduction of profected energy consumption by 1980 .

As will be discussed later in this chapter many of the elements in each state's plan require supplemental action and support for their jnftiation and management. For example, the designation of agencies to develop and enforce lighting and thermal efficiency codes requires state legislation. Home energy audit programs, developed by several states, require administrative and financial support and intensive staffing. Such needs keep the elements of energy programs and an awareness of many basic issues in the minds of state legislatives and executive officials.

*Wh1 re House Press, Release, Apr11 20, 1977. 
The issues and activities discussed in this chapter have emerged as a result of activities preceeding and following the OPEC embargo and, more recently, the effects of short term problems and changing state and national policies. Current emphasis on energy affairs is largely, although not entirely, a result of the four factors discussed previously. Retention of this generally intense interest depends on the absence of over-riding non-energy related issues such as prolonged debate over the state budget in Pennsylvania which left state employees unpaid for four weeks. 
PETROLEUM

\section{Delaware}

Delaware has perhaps the toughest coastal zone legislation in existence. Its 1971 Coastal Zone Act bans heavy Industry including refineries, milis, deepwater ports and pipelines from a two mile strip along the state's coast. In its final report to the Governor in 1976 the "Delaware Tomorrow Commission" recommended that the Coastal Zone Act be replaced with a comprehensive statewide planning act. In addition the Commission also recommended that the state be alert to and involved in deepwater terminal and offshore drilling activities both to reap the benefits of reyenue and jobiopportunities and maintain control and mitigate undersirable environmental effects. Subsequently two drafts of legislation were prepared for but not presented to the General Assembly. One, prepared by the President of the Delaware Bay Transportation Authority, would permit a superport and alleviate the current ban on heavy industry. Sussex County administrator Joseph T. Conway, who proposed a similar measure, said that any of the county's legislators would be willing to present a bill contalning the concept of a permissable superport. (Land Use Planning Reports, April 18, 1977).

Maryland

In 1974 the state enacted legislation banning oil companies from operating retall service stations. The oil companies went to court and in March, 1977 the Maryland Court of Appeals, In a unanimous opinion, upheld the law noting oll company favoritism in supplying company owned locations during the gas shortage of 1973 and subsequent attempt to eliminate competition from independent dealers by taking over their stations.

In an April 16, 1977 article the Baltimore Sun reported that Federal Judge C. Stanley Blair rejected six independent oll firms' offers to plead no contest to criminal conspiracy charges. The case Involves an alleged seven-year consplracy to ralse prices through a six-state area and the District of Columbia which, according to Mr. Rodney O. Thomson, an assistant in the Antitrust Division of the Department of Justice, was proof 
of the oil companies enormous power over "thousands and thousands of retail gas stations". Judge Blair, in rejecting the companies' pleas, said the case "will be burdensome and costly to thy" but "the public interest in any event, is determined by the type of case." If the companies are guilty, he said, "they have substantially affected the public interest."

\section{New Jersey}

The 0il Spill Compensation and Control Act has sparked controversy in the state. The Law (signed Jan. 6, 1977) orders the Department of Environmental Protection to enact rules and regulations defining hazardous substances covered by the $1 \mathrm{aw}$, set procedures for notification in the event of spills, nequired prevention and control plans, required owners of facilities to monitor for groundwater pollution; and taxed oil transported into the state (such taxes to be used for the creation of an oil spill liability fund).

The New Jersey Petroleum Council. claims the regulations go "far beyond the legislative intent", an allegation supported by $\mathrm{H}$. Donald Stewart (DSalem) who said the regulations exceed the legislative mandate and who may propose changes. The petroleum companies responded in a similar manner: the proposed regulations are "costly, impractical and burdensome" and might prohibit oil companies from siting new facilities in the state.

D. Bardin, Commissioner of the DEP, testified that the Act "passed to protect people and natural resources" was "the most comprehensive state law of lts kind" and designed to prevent, control, and compensate "for spills which could do untold damage...."

\section{New York}

The state joined the Natural Resources Defense Council in filing suit (N.Y. vs Kleppe, No 76-1229. E.D.N.Y.; June 29, 1976) dyalnet the Jcpartment of Interior in an attempt to delay federal oil and gas leasing on the outer continental shelf. Their briefs claimed that the environmental impact statements were inadequate, that DOT violated goyernmental cooperation statutes and regulations, the Coastal Zone Management Act, and a number of wildlife protection laws. 
Federal Judge Jack B. Weinstein of the U.S. District Court volded the sale of leases (permitted by the stay of an injunction by the Circuit Court) finding that there was "considerable evidence that environmental impact statements and public hearings for the issues had been a charade."

Reactions to Judge Weinstein's decision have been mixed. Mayor Abraham Beame (New York City) called it "yet another setback to the urgently needed development of new energy sources for the Northeast." On Long Island several officials noted that compliance with standards set forth in NEPA "is what we have been demanding from the outset."

In August the Federal Appeals Court over-ruled Judge Weinstein's decision, an action which will allow the leasing and exploration of Atlantic ocs areas to proceed.

Puerto Rico

Commonwealth 0 il Refining Company (CORCO) operates the principal petroleum refinery in Puerto Rico ( $161,000 \mathrm{bbls} /$ day). According to newspaper reports the excessive price of crude oil has created an unsupportable situation for the refinery: over the past three years it has lost almost $\$ 78$ million dollars and has continued operation only through subsidies from the FEA and can continue operations only if it is granted additional concessions from FEA.

The refinery is of extraordinary importance to the Commonwealth. Its products are necessary for the operation of homes, commerce and industry. Electricity is generated by the Autoridad de Fuentes Fluviales with fuel supplied by CORCO. Gasoline consumed in transportation is refined by CORCO. While not a monopoly the loss of this refinery would have extensive detrimental impacts on the economy and life of the Commonwealth.

\section{Virginia}

The State Water Control Board has granted a conditional permit to the Hampton Roads Energy Company for the construction of a $\$ 550$ million oil refinery near Portsmouth. The conditions are essentially two: (1) that the company accept all responsibility and llabllity for cleaning up ofl splils 
caused by tankers approaching or leaving the refinery's terminal; and (2) that 180 days prior to its scheduled opening of the refinery the company file with the Board an oil-spill clean-up plan and that the company not begin operations at the refinery until the Board has approved the plan.

Robert Porterfield, Vice President of the company, said he will wait (and watch four bills which would change the responsibility for containment and cleanup of oll spills) before submitting the cleanup plan. "I don't want to have It in the mind of anyone that we're trying to evade responsibility" he sald, and added that lawyers retained by the company feel the Board's stipulations might be 11 legal. 
NATURAL GAS

Shortages of natural gas over the past winter coupled to the sharply increased prices of supplemental gas have led the Federal Power Commission (at the request of Senator Howard H. Metzenbaum, D-Ohio) to order an investigation into allegations that the regions major natural gas company's (Columbia Gas). shortage of natural gas was the result more of bad judgement than of the harsh winter. The company was to come before an FPC tudge in an accelerated hearing process on April 8. To date (August) this case has not been settled. Analysis prepared by Brookhaven National Laboratory (Draft, A Preliminary Assessment of the Impacts of the National Energy Plan on the Northeast) suggests that, as the experience of the past winter demonstrated all too clearly, the accident of geographical location in terms of the dependence on a particular pipeline company that faced differing levels of curtailment resulted in interregional inequities so blatant that the Emergency Natural Gas Supply Act of 1977 finally gave the FPC power to equalize curtailments among pipeline companies. Consequently the NEP proposal to extend this Act a further three years is of vital concern to the region.

At the same time gas producing states in the region are expertencing a surge in exploratory and production drilling. The Oil and, Gas Compact Bulletin (June, 1976) reported that drilling activities had increased in Ohio, Pennsylvania, New York and West Virginia. Renewed interest in Lake Erle exploration has caused considerable controversy in New York, Ohio and Pennsylvania. In all three states bills had been filed which both extended the existing ban on Lake drilling and lifted the ban entirely. Gov. Shapp has lifted the ban in Pennsylvania. In Ohio the House extended the ban prior to recessing but the Senate, which had passed a bill calling for three natural gas test we11s, Immediately refected the House version. In New York a bill allowing natural gas exploration in the Lake awaits Gov. Carey."s signature.

New Jersey

Congressman Bill Hughes (D-NJ) charged that approximately one trillion cubic feet of gas that could be used in the interstate market is being used by producers to run refineries. Hughes sald the use of regulated gas falls 
outside FPC authority as it is within the "gathering facility" exemption which allows up to 50 percent of offshore gas to be reserved to producers. In related findings in a report prepared at Princeton Unviersity for Brookhaven National Laboratory Dr. David Morell said New Jersey's supply of natural gas could be increased by 8 percent if gas could be diverted from refiners to high priority users, that only higher prices will cause consumers to cut down on consumption, and that the natural gas shortage resulted from a actual shortage of reserves.

New York

Legislation regulating the siting of facilities to store and convert natural gas laas beè passed.

Industries in New York seem to be moving towards securing natural gas independence. Exemplary of this is Miller Brewing Company which has an application pending with the PSC to drill gas wells around Auburn, NY, build a compressor plant on a site outside the city, and construct a pipeline to its brewery and can plant. The Auburn Mayor hopes to convince industry that the city and surrounding townships can be established as a center of natural gas reserves--a prime location for Industrial development.

$\underline{\text { Ohio }}$

Governor Rhodes advocates deregulation of prices on gas from new natural gas wells and total deregulation in five years. According to the Columbus Evening Dispatch, Rhodes intends to pursue an aggresive program of energy independence for Ohio including, if necessary, a law to prevent gas stored in-state from moving to other states. Rhodes specific target is an $\$ 80$ million underground storage facility Columbia Gas wants to develop in Fairfield County. Columbia officlals Frederick Laird and Marvin White warned khodes that a parochial approach could backfire in a state which imports over 90 percent of its natural gas. 


\section{$\underline{\text { Pennsylvania }}$}

The Pennsylvania Science and Engineering Foundation is supporting a mining engineering project to test the feasibility of tapping coal seam methane gas resources. The project is seen as having two primary benefits: first, the commercial production of enormous quantities of commercial quality gas; and second, mine safety improvement through degasification prior to mining.

In Philadelphia a decision to construct a $\$ 72$ million synthetic natural gas plant taken by Mayor Rizzo and the Gas Commission has sparked a controversy. According to a report in the Philadelphia Evening Bulletin the plant, for which site clearance is underway, will replace an existing oil-gas plant, and will cost from \$20-30 million more than the price tag on other SNG plants built in recent years. According to the newspaper two reports, one prepared by Loeb Rhodes a New York Investment house and the second by Purvin and Gertz, Inc., Texas engineers, warned the city that it could have access to enough natural gas in the future that the new plant will be unnecessary. City Councilwoman Beatrice Chernack has introduced a resolution calling for a special investigation into the matter.

\section{West Virginia}

Despite the state's role as the largest natural gas producer east of the M1ssissippl River it is expanding efforts to increase production by exploration, research into new techniques of recovery, and legislated incentives. Columbia Gas plans to sink 32 new developmental wells and 8 new exploratiory wells in the state this year. Columbia and ERDA are conducting parallel programs to develop technology for freeing gas in the Devonian Shale and tight sandstone formations. West Virginia Congressperson Robert $\mathrm{H}$. Mollohan has Introduced federal legislation exempting small natural gas stripper wells from federal regulation as a means of increasing production. 
COAL

The states comprising this region are faced with a variety of issues in developing and utilizing coal. Examination of the ESECA experience shows that a disproportionate share of prohibition orders occured in the region: approximately 6150. MW or $43 \%$ of the total national generating capacity under prohibition order is in these Mid-Atlantic states (Table 76). While implementation of the coal policies in the National Energy Plan (NEP) is based, in part, on full implementation of Round 1 and Round 2 ESECA coal conversion the program has had problems. The Federal Register, Vn1; 4?, No. dila roports that Lle Administrator of the EPA has certified that 36 units at 15 plants are ineligible for compliance date extensions, of which, 21 unitg representing $72 \%$ of the regional conversion capacity are in the Mid-Atlantic States. To date the EPA Administrator has not notified the FEA of the date on which these sources can burn coal and comply with all standard conditions and required ifmitations.

At the heart of ESECA conversions in the region lie questions of air quality maintenance and additional pollution control investments. As exemplified by the Ohio debate the utilities take the position that conversion costs are consistently underestimated and it would be unreasonable for them to incur significant expenses for equipment to mpet standarde which may be tightened in the future.

Aggravating the situation is internal interest on the part of the states which would like to benefit from the employment and economic impacts of Indigenous coal resource development. Yet as Brookhaven's analysis of the NF.P indicates it is by no means clear that all producing states in the region will benefit from the presumed substitution of Appalachian for western coal; Ohio and Kentucky are far more likely to benefit. Sccond, it is by nu means clear that burning high sulfur coal with scrubbcro necessarily iesults in lower emissions than burning low sulfur western coal without scrubbers, which raises a number of issues related to the interstate transport of air pollutants and the concommitant environmental and health impacts to the Northeast; and third, the hoped for revitalization of the Pennsylvania anthracite industry is crucially 
UTILITY PROHIBITION ORDERS IN THE REGION, ROUNDS 1,2

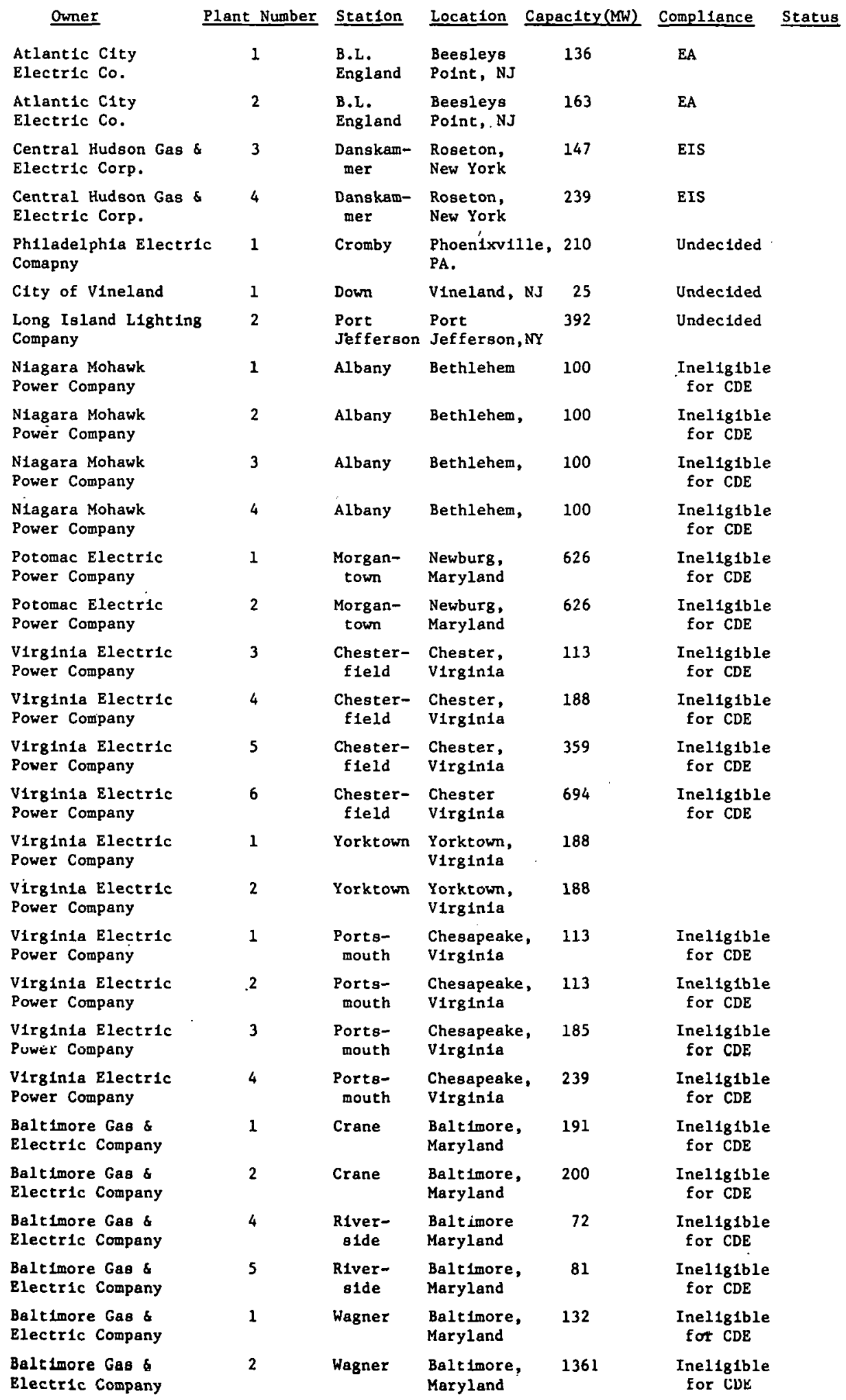


dependent on being able to meet state SIP's without scrubbers, from which follows that if BACT does indeed require scrubbers even for low sulfur coals, prospects for exploiting this resource are considerably dimmed.

Similarly, institutional and labor problems may compound expectations on the balance of eastern versus western coal and the ability to reach NEP. coal utilization goals. Prolonged wildcat strikes such as that which occured in five Appalachian states; which began in West Virginia as a protest over cuts in United Mine Workers health benefits, have idled up to 85,000 miners and reduced 1ndustry production predictions to 1976 production levels.

Ohio

A strident conflict has developed over the use of coal in ohio. On one side stands George Alexander, EPA Midwest Administrator who, on the basis of the congressional Clean Air Act of 1970, informed the state (August, 1976) that stack controls or the use of low-sulfur fuels would be necessary in 55 counties and for 137 specific power plants, factories, and institutions in order to meet clean air standards. Ranged against Alexander are a variety of utilities, labor leaders, legislators, and state agencies. Utility consultants say the EPA has underestimated the capital cost of conversion by approximately $\$ 150$ million and the operating costs by $\$ 164$ million. Mr. Susey of OERDA said the EPA plan would cost 7,100 coal mining jobs and substantially reduce coal produstion. Labor agreed, if wot with the numbers, at least with the concern.

To protect against the importing of coal to the state Ohio Representative Authur Bowers said a House Committee is considering legislatinn wh1ch w111 prohibit utilities from passing on the additional cost of cnal obtained from outside Ohio unless such acquisition is approved by the General Assembly. Violators may be fined or imprisoned or both.

Governor Rhodes reportedly is talking with Ohfo coal producers about a large hike in the states severance tax to finance a $\$ 15$ to $\$ 20$ million a year coal research program, including coal desulfurization research. There are also several legislacive proposals increasing coal taxes. 
The Ohio Energy Resource and Development Authority has funded a variety of coal research projects. Among them are a project to determine the feasibility of using water from abandoned underground mines in coal gasification and a study of the location and composition of deep coal deposits in eastern Ohio.

Pennsylvania

Pennsylvania does not face a similar problem, its regulations control the emissions and not the sulfur content of the fuel. Morris Malin, chief compliance officer of the State Department of Environmental Resources indicated that Pennsylvania coal can be burned in some areas without cleansing or stack collector systems but it cannot be burned in specified air basins without cleansing.

The Governors Energy Council has recommended the following coal policies:

Prompt and equitable administration of laws and policies regulating coal use;

The provision of efficient rall transportation for coal;

Increasing the efficiency of coal combustion;

The cleansing of coal by chemical and mechanical means;

The development and use of new and improved technologies to enhance. the health, safety and productivity of coal miners, and;

National policies restricting petroleum use in industry and protecting development of a U.S. coal Industry. Virginia

The General Assembly has revised Virginias surface mine reclamation law to require a $\$ 200-1000$ hond per acre to Insure that all mined land is returned to productive use. Recent Congresslonal interest in regulating surface mining practices resulted in a bill exceeding the state requirements. Though vetoed by the President, there is still active interest in the bill. The state is concerned that its laws will not be in compliance with such legislation, and that coal demand will be adversely affected by the resulting increase in the price of coal.

Other problems for coal development include the closure of smaller coal mines due to increasing regulatory costs, the coal-haul roads are in poor shape, venting methane is expensive and the gas is wasted, water quality 
problems from strip mining, production in the state is market limited, inflexible federal regulations which do not allow for regional differences, and the lack of federal incentives for gasification and liquefaction.

\section{West Virginia}

The state is currently involved with two important coal technology demonstration plants: 1) a 2-3 megawatt fluidized-bed combustion unit in Reidsville, and 2) a coal liquefaction plant in Creseps. West Virginia University has undertaken a study to determine the feasibility of setting up coal complexes throughout the state that produce natural gas, petroleum liquids, and electric power.

Based on interviews with state officials it appears that environmental constraints are the major issue facing increased coal development in the state. If proposed changes to water quality regulations are adopted in their present form the coal industry will be required to change methods of current operation. Gov. Rockefellar stated before a Senate Committee in March that federal strip mining legislation equalizing reclamation standards would help alleviate the state's distinct competitive disadvantage in the marketplace. While the coal industry in the state is currently suffering from inequitable reclamation standards and may be losing grnind in tarme of watcr pollution control, it is gaining in terms of air pollution control. Action by the W.V. Air Pollution Contrnl Commission (folluwing an execuldve order that state standards be no more stringent than federal standards) was recently approved to relax sulfur-dioxide standards. Principal beneficiaries of the action are producers of high-sulfur coal in the northern counties. 
NUCLEAR

New Jersey

In May of 1971 the Public Service Gas and Electric Company (PSG\&E) announced that it would investigate the feasibility of siting one or more nuclear plants offshore. In March of 1972 the choice of site was completed and Public Service announced that the station would be located approximately 2.8 miles offshore from Little Egg inlet on the coast of New Jersey. The plants, the Atlantic Generating Station as they would become known, provided a radical contrast to the existing pattern of nuclear power development and it was hoped that they would alleviate many of the burdensome constraints which faced electric utilities seeking to site nuclear generating stations. First, the utility hoped that the permitting procedure would be shortened and simplified by the selection of sites offshore. Second, Westinghouse and Tenneco, on receiving a notice of intent from PSG\&E announced the formation of an unincorporated joint venture, offshore Power Systems, to design and construct floating nuclear power stations on a production line basis, thus providing standardization of plants and economies in construction not available to onshore facilities.

Although the reactor design was approved by the Nuclear Regulatory Commission (NRC) and the site selection process reached the EIS stage the project has been at least temporarily delayed. A number of reasons for this have been postulated: lower than expected load growth in New Jersey lessening the need for new capacity additions, financing problems in a joint-capital long term venture and greater than expected local opposition. Whatever the case PSE \&G postponed their order and Tenneco subsequently bowed out of the unincorporated venture. (Electrical World, Aug. 15, 1977)

Two recent developments have also sparked debate about nuclear power In southeastern New Jersey. The first was proposed legislation relating to the creation of a new state agency with powers to locate energy facilities. The second was the final report of a two year study of a hypothetical cluster of twenty nuclear plants in Ocean County. Among the reasons advanced for 11kely opposition to such a plan (cluster siting) are current concerns about past operating problems with the Oyster Creek nuclear plant, the effects of 
nuclear power on tourism-foundation of Ocean County's economy, past opposition by public officials to nuclear power, and major questions about evacuation in case of an accident.

It is unclear whether opposition to a site identified for a generic cluster study can be equated with opposition to existing dispersed siting activities. However, local opposition to nuclear power is great; particularly in those areas with existing nuclear facilities. "Why us?" asked Freeholder Leonard J. Connors Jr. "When is it enough? Energy is everybody"s problem, but all these plants seem to localize in Ocean County in south Jersey" In Salem County the Board of Freeholders has also expressed their feeling that the County has already sited enough nuclear plants.

If Governor Byrne's proposed legislation relating to the dispersal of taxes from generating facilities is passed, local opposition to facility siting may increase. One of the primary benefits of nuclear plants to localities in New Jersey has been revenue derived from the operation of such plants.

\section{New York}

Opposition to nuclear power appears strong in the state but, as with New Jersey, it appears to intensify as one approaches specific proposed sites. On: Long Island local opponents of the proposed Jamesport plant recruited "nationally known nuclear experts" to present opposing testimony to the NRC. Among their numbers were an epidemiologist in the State Health Department, a former AEC "radiation scientist", a Boston pediatrician, and Dale Bridenbuangh formerly a General Electric nuclear engineer.

In August Newsday reported that Suffolk County Executive John H. Klein said Lilco was "going off the deep end" in describing the consequences of not building the plants and accused the company of making unfounded "threats" to the people of Long Island. Meanwhile, the paper reported, otaff of the NRC urged the Commission to issue permits for the construction of the plants and the New York State Public Service Commission refused to reopen hearings on Lilco's application before the state to bulld the two power plants. Meanwhile Gov. Carey is reported to have stated that he will not approve the Jamesport plant until problems of radiological waste disposal have been resolved. 
In Poughkeepsle Mid-Hudson Nuclear Opponents (NO), the reglons principal anti-nuclear organization, in the spring called for public mobilization against tentative plans by Con Ed to bulld a four plant nuclear complex either in Ulster or Dutchess County. "If the Con Ed project is allowed to materialize" said Dr. Peter D.G. Brown (NO Chairman) "by the 1990's there will be no less than 10 nuclear power plants within a 50-mile radius of Poughkeepsie. The net result of all these plants would give the mid-Hudson Valley one of the largest concentrations of nuclear power in the world."

In 1976 the state assembly declined to act on what environmentalists argued was one of the most important bills of the session. The Nuclear Responsibility Act, which would ban the construction on opposition of nuclear plants in the state unless they had "successfully tested" emergency systems and procedures for radioactive waste disposal, were assured of a supply of uranium, and had developed an evacuation plan for nearby residents in case of an emergency, is expected to be a major issue in future sessions.

Responsibility for the Nuclear Fuel Services (NFS) nuclear fuel storage and processing complex in Cattaraugas: County, $N Y$ is of concern in the State. NFS has notified NYSERDA of its intent to surrender responsibility for the nuclear wastes on the site in accordance with applicable agreements and has also indicated its decision not to renew the lease for the site upon its expiration on December 31,1980 . New York maintains that the U.S. Government has an obligation to acquire the site and accept the responsibility for its contents. While this has not yet been accomplished, the U.S. House Government Operations Subcomittee is drafting legislation to provide ERDA with funds so that it can safely decommission the plant. Unanswered questions have made it difficult to estimate clean up costs according the Monte Canfield, an energy authority with the General Accounting office. Among the questions:

-What is the exact composition of high level wastes?

-How should these wastes be disposed of since they will be dangerous for over 250,000 years?

-What should be done with the processing plant, which is contaminated with radioactivity?

-What w111 happen to the 3,345 acre site? 
Ohio

The first commercial nuclear generating unit in Ohio, Davis-Bessie, was scheduled for start-up and trial operations in the first week of August, 1977. The station was not expected to reach its full output of 960 MW until three weeks later. Nearly 10 years in planning and construction, at a cost of $\$ 535$ million the plant will supply power for the Toledo Edison Co. service area. Two additional units, each with a 960 MW capacity, have been approved by the Ohio Power Siting Commission on the Davie-Bcosie site.

Another nuclear station, with two rearter uniton, has boen piupused for adjacent Erie County near Berlin Heights. Administrative Law Judge Ralph E. Risken has granted a request by the Ohio Power Siting Commission for additional time to investigate the two units. In addftion intervenor status has been requested by both pro and anti-nuclear groups. One individual granted intervenor status, Stanley Barylski, is reported as not having the financial requirements nor expertise for effective intervention and will submit a short protest statement in lieu of interrogation.

Voters rejected an initiative measure to ban nuclear power plants unless they proved their safety.

\section{Virglnia}

In the Matter of Virgintn Flectris and Puwer Compuny, Nos $\mathrm{C}_{\bar{P}} \mathrm{PK}-7 \%,-78$ (NRC, Nov. 12, 1976) the NRC reversed the Atomic Safety and Licensing Appeal Board and assessed a fine against VEPCO for material false statements, including omissions, in connection with its application for construction permits for Lhe North Anna, Virginfa nuclear power facflity. While granting that the Commission lacked regulations governing full applicant reporting the Commission found that materiality must be juiged on whether a reasonable staff member should consider the Information in hila jot. Sllence regarding lupurtant lssues, therefore, is covered by the statutory phrase "material false statements".

The material false statements in this case concerned the failure to supply information relative to a geologic fault which had been discovered 
at the North Anna site. The Licensing Board ultimately concluded (June 27, 1974) that the fault was non-capable and without significance for the facilities in question.

More recently, a former employee of the Virginia Electric and Power Co., Nathaniel Hatch Jr., former auditor at the North Anna site, charged that the utflity wasted through mismanagement and poor labor practices more than $\$ 60$ million in the construction of the nuclear station. The Richmond News Leader reported on July 28, 1977 that after a meeting with Mr. Hatch the State Corporation Commission decided to ask for specific audit reports from Vesco relating to alleged discrepencies at the site.

Virginia has passed legislation requiring the bonding of certain facilities handling radioactive material (H488).

\section{Puerto Rico}

Puerto Rico depends, at present, exclusively on foreign oil to produce the electricity it needs. Consequently, the Puerto Rico Waster Resources Authority (PRWRA) had planned for the construction of a $600 \mathrm{MW}$ nuclear plant. The first profect, Aguirre Nuclear Plant, was scheduled for operation in December 1975, but is was abandoned under pressure of the late Atomic Energy Commission (AEC) when no agreement was reached between the AEC and PRWRA technical advisors in regard to undefined geological matters. Due to this unfortunate situation, additional siting studies were performed on and around the Island of Puerto Rico. This caused the project to be rescheduled for construction on the north coast (NORCO Nuclear Plant) to start commercial operation in January 1981.

In 1974, the un1t was deferred to 1985, and on December 1975, it was postponed indefinitely. Cost of the profect had increased from $\$ 140$ million. to over $\$ 600$ milition and its financing is now beyond the Authority capabilities with the present rate structure. 
SOLAR, WIND, SOLID WASTE

Most of the states in the region are advocates of these alternative energy sources but few are expending much financial support for their development. It is felt that without greater federal support development will be dependent on legislated incentives (such as tax breaks outlined below), local action (in the planning of waste utilization systems), and private enterprise to overcome the barriers to development. For solar and wind systems such barriers include high inttial costs, need for conventional back up systems, lack of service personnel, avallability of component guarantees, and the lack of technical expertise in state agencies dealing with solar information requests. The redicion of those states in the region eligible for residential solar grants under the Department of Housing and Urban Development residential solar hot water program (New York, New Jersey, Pennsylvania, Delaware and Maryland) to delays in administration of the grants is not clear. Manufacturers of the systems feel that the delay is necessary for adequate testing of solar hot water systems prior to the establishment and selection of systems meeting HUD grant guidelines.

FOr solid waste or biomass systems the barriers differ. In general they concern the availability of waste or biomass resources, the ability to reach accord between municipalities conperating in the development of such systems, the cost sharing requirements of joint systems, and the siting of plants. Maryland

The state passed legislation (H.B.1644, P.L. Chapter 509) which provides that solar heating and cooling units in residential and nonresidential bulldings be assessed for property tax purposes at no more than the value of a conventional heating and cooling system necessary to serve the building.

New Jeisey

Legislation before the Senate (passed by the Assembly 61-0) exempts solar heating or cooling equipment in any bullding (whether residential, commercial, or Industrial) from taxation. The Senate has forwarded a bill to the Assembly which exempts solar equipment sold in New Jersey from the state sales tax. 
New York

The state is participating in a variety of solar, wind and solid waste research and demonstration projects. For example, the N.Y. State Energy Research and Development Authority has contracted for the construction of a demonstration wind generator on a working dairy farm in St. Lawrence County. The project is designed to examine the technical commercial, and environmental feasability of generating electric power via wind. The farm will operate a part of its dairy barns, feed silos, as well as the family's cooking, bathing and heating needs with wind generated power.

There are a number of active proposals for refuse burning systems in the state. Several have advanced so far as to file an environmental impact statement with the DEC (e.g. a $\$ 48.5$ million refuse facility proposed for Syracuse). Most proposed projects are troubled by several problems including the availability of sufficient refuse to run the plant, opposition of refuse collection contractors and the selection of acceptable sites.

Governor Carey recently signed legislation offering a 15-year tax incentive to any property owner who installs a solar or wind energy system.

$\underline{\text { Ohio }}$

At least two solar energy bills have been filed by legislators. One would offer a sales tax exemption for solar equipment and in income tax credit (up to $\$ 1,500$ ) when such systems are actually installed, another would define solar rights.

Pennsylvania

Three bills have been filed in the House $(334,335,336)$ which would exclude solar energy systems from the sales and use taxes and exclude the value of such systems in determining the value of real estate.

As part of its Energy Conservation Policy the Governors Energy Council has recommended that state contractors demonstrate their efforts to incorporate innovative energy sources such as solar in all work performed for the state and the GEO will work with the Department of General Services to promote demonstrates of the use of ...solar, waste heat, and solld waste generated energy. 


\section{$\underline{\text { Virginia }}$}

An estimated three dozen buildings have been outfitted for solar energy systems. One example is the Terraset Elementary School in Reston which is now under construction. Present plans call for 5-7000 square feet of evacuated tubular glass collectors, three 10,000-gallon storage tanks, and a 40-ton solar-driven air conditioner. The building is set almost completely underground. The use of insulation and sun-shielding properties of the earth is expected to reduce energy requirements to about half those of conventional structures of comparable size. Four contracting firms are participating in a HUD-sponsored program to install solar demonstration units in new and existing residences to provide the public with a first-hand view of the practical application of: solar energy for heating and cooling homes under varying climatic conditions.

By late 1979 an $\$ 8.4$ million trash-fired steam generating plant will be built at Hampton and is expected to save the city $\$ 300,000$ annually in solid waste disposal costs. The 225-ton-capacity plant, RECOUP, will burn garbage from the city, NASA's Langley Research Center, Fort Monroe, and the VA hospital. All steam generated by the plant will be sold to Langley. The project is an unprecedented partnership between local government and federal agencies.

\section{Puerto Rico}

The Puerto Rico Water Resources Authority (PRWR ) recently completed a study for the National Science Foundation (Grant No. APR75-18301) to determine the financial and technical impact on a public utility that may be caused by the intensive use of solar cooling and heating by subscribers. 


\section{ALTERNATIVES}

There is very little interest in long-term esoteric technologies. From the states viewpoint such activities fall entirely into the realm of federal perogative: to the states a 10 year time horizon is long-term planning, anything beyond that is not generally applicable to current policy makers. Thus, the development of alternative energy technologies in the states is a function of improving the use of available in-state resources not covered in previous sections. These are essentially two: blomass utilization and hydro power development.

The potential for developing biomass/energy systems in the region is generally good: extensive tracts of timber are available in N.Y., Pa., N.J., MD., Va., and W.V., and many of these states (as well as Delaware and Ohio) also have extensive agricultural wastes. The incentives for utilization are recognized by most states. They recognize the resource is generally renewable, that it is available for use, that improved utilization can be linked to timber stand Improvement through development of a management system, and that the economic benefits which accrue may be great. But, they also realize that biomass systems have drawbacks which constrain their development: the resource is dispersed and bulky thus expensive to collect and transport; the land ownership pattern is complex and disaggragate thus the purchase of control of resources seems impossible; few landowners seem liable to give long term timber cutting contracts thus the availability of contractual control of resources in an economically discrete area is problematic; there is uncertainty as to the environmental impacts of resource recovery and use systems and the level of regulation to be exerted by federal and state governments thus developers are unclear as to the cost of reclamation and control technology; recent research developments Into the uses of biomass have opened new and potentially economic uses creating an alternative demand for the resource; and, demand for wood resources by the timber industry creates a potential resource conflict. Because of such problems the states do not aggressively encourage biomass utilization but seem to defer to government or private enterprise.

Th1s passivity is not shown in those states with undeveloped hydropower potential. While large scale projects comparable to Tocks Island (on the Delaware River) are not being pursued by the states (because of potential 
environmental conflicts) smaller projects have generally been welcomed. According to newspaper reports Niagara Mohawk plans to ask the FPC for approval to expand or construct 15 hydroelectric facilities including a new power dam across the Hudson. Seventy percent of the proposed installations will be in the upper Hudson Basin. The projects are estimated to have the potential to add 205,000 kilowatts to the utilities generating capacity and to cost between $\$ 150-200$ million dollars. In addition, a recent report in the Watertown Daily Times (N.Y.) stated that the latest Federal Power Cominission (FPC) survey has identified 34 sites (some of which duplicate the sites identified hy Niagara Mohawk) with a potentlal installed capactty of $540 \mathrm{MW}$.

In Virginia the Staunton River hydroelectric project proposed by the Southside Electric Cooperative will require Congressional approval. According to a letter from Major D.B. Bulgar (Corps of Eng.) to Rep. W.C. Daniel, Maj. Bulger said "if the .....studies indicate that success of the projert is dependent upon modification of the Kerr project (a pump storage project) the Corps of Engineers must submit a review report to Congress for approval and authorization.

The Department of Marine Sciences of the Unfversity of Puerto Rico, Mayaguez Campus, performed a study sponsored by the National Science. Foundation (Grant No. AER 75-0014.5) to evaluate the cnergy feaslbility and the environmental impact of the operation of an ocean thermal energy plant at a site located a few miles away from the southeast coast of Puerto Rico. The study showed that the site has excellent characteristics for the operation of such a plant. According to the researchers, the Punta Tuna site offers the best characteristics of all the sites that have been studied in the world to install a land based OTEC plant. 


\section{CONSERVATION}

By far the major state conservation efforts in the region are being carried out under the auspices of the Federal Energy Administration Conservation Program pursuant to the Energy Policy and Conservation Act. The FEA requires that the state conservation plans include five mandatory policies (discussed in the introduction to this chapter) and such other elements as are necessary to achieve a $5 \%$ savings of projected energy demand in 1980 .

As shown in Tables 77 through 82 the policles in the state plans include many elements not required by the FEA.* For the states whose plans (or drafts) were available severable interesting aspects should be noted. First, the mandatory conservation policies alone are not sufficient to approach the required savings and the states have developed elements which, with enhanced support, could develop into major energy demand reduction factors. As the tables show several states have policles which, if applied in other areas, could increase conservation reductions beyond current estimates. Second, as the residential and commercial conservation policles suggest benefits derived from improved energy-efficlency in existing residences and commercial and public buildings are as great if not greater than codes relating to new construction. Third, the Industrial conservation policles seem to imply that the states expect conservation of Industry but, except for utilities, cannot specify what policies need to be implemented and may not have the oversight authority to require improved energy efficlency, Fourthly, of the four conservation sectors discussed, policles in the transportation sector achieved the lowest percentage of demand reduction. Major savings in this category are generally to be met by car and van pooling and enforcement of the $55 / \mathrm{mph}$ speed limit. Finally, as appears in the plans reviewed for this section and other chapters of this document, no recognition is given to the energy conservation and management implications of Improved land use management practices yet the implications of such practices for transportation planning, waste utilization, refuse use, co-generation and district heating are large. *

IVirginia Energy Conservation Plan, Virginia Energy office

2 West Virginia Energy Conservation Plan, WV Fuel and Energy Office

3 New York State Energy Conservation Plan, New York State Energy Office

4 The New Jersey Energy Plan: A Necessary Commltment prepared by Resource Planning, Inc., and Wilbur Smlth and Assoclates under direction of the New Jersey State Energy Office.

5

State Energy Conservation P1an: Governors Energy Counc11 
TABLE 77

Estimated 1980 Conservation Savings

by Sector

(estimated 1980 Savings, $10^{12}$ Btu)

New Jersey New York Pennsylvania Virginia West Virginia

\begin{tabular}{|c|c|c|c|c|c|}
\hline Residential & 54.12 & 91.0 & 67.58 & 14.91 & 5.49 \\
\hline Commercial & 32.4 & 92.2 & 37.5 & 21.31 & 39.53 \\
\hline $\begin{array}{l}\text { Industrial, Agri- } \\
\text { cultural, Ut1lity }\end{array}$ & $37: 5$ & 52.8 & 157.91 & 32.27 & - \\
\hline Transportation & 14.2 & 36.2 & 39.122 & 7.24 & 6.03 \\
\hline Cross-Sectoral & 0.35 & 35.4 & 0.14 & 2.94 & 7.68 \\
\hline Total & 138.57 & 307.6 & 302.52 & 78,67 & 52.73 \\
\hline $\begin{array}{l}\text { Percent of Profecte } \\
1980 \text { Consumption }\end{array}$ & 6 & 7.3 & 6.9 & 5.48 & $5 . \varepsilon$ \\
\hline
\end{tabular}




$$
\begin{gathered}
\text { TABLE } 78 \\
\text { Residential Conservation } \\
\text { (estimated } 1980 \text { savings in } 10^{12} \text { Btu) }
\end{gathered}
$$

Policy

Certification of existing homes

Gas Pilot Light ban

Furnace Inspection and Maintenance

Home Audit, Inc. (and retrofit)

Individual Metering

Weatherization

Thermal Efficiency Standards, New and Renovation

Water Conservation Code

Voluntary Energy

Conservation

TOTAL
New Jersey New York Pennsylvania Virginia West Virginia Total

$18.1 \quad 3.1$

21.2

6.85

a

6.85

$15.4 \quad 5.2$

20.6

$75.2 \quad 54.1^{\mathrm{b}}$

11.3

140.6

0.05

4.5

1.58

0.03

2.11

0.02

3.0

1.66

0.3

0.94

5.92

10.7

10.24

4.55

25.49

3.0

3.0

3.28

3.28

54.12

91.0

67.58

14.91

5.49

229.05

an effected policy but no estimated savings.

${ }^{b}$ Savings from the commercial sector are also included in this estimate. 


$$
\begin{gathered}
\text { TABLE } 79 \\
\text { Commercial Conservation } \\
\text { (Estimated } 1980 \text { savings in } 10^{12} \text { Btu) }
\end{gathered}
$$

\begin{tabular}{|c|c|c|c|c|c|c|}
\hline Policy & New Jersey & New York & Pennsylvania & Virginia & West Virginia & Tota1 \\
\hline Thermal Standards & a & 28.7 & 15.6 & 9.92 & & 54.22 \\
\hline Lighting Standards & 14.4 & 38.5 & 21.9 & 3.68 & 2.1 & 80.58 \\
\hline Code Review & & 25.0 & & & & 25.0 \\
\hline Audits & & & $\mathbf{a}$ & & $36.4^{\mathrm{b}}$ & 36.4 \\
\hline $\begin{array}{l}\text { Retrofit of Pubiic } \\
\text { Bldgs. }\end{array}$ & 18 & & & 3.19 & & 21.19 \\
\hline $\begin{array}{l}\text { Retrofit of Com- } \\
\text { mercial Bldgs. }\end{array}$ & & & & 4.52 & & 4.52 \\
\hline TOTAL & 32.4 & 92.2 & 37.5 & 21.31 & 3.13 & 221.91 \\
\hline
\end{tabular}

\footnotetext{
Estimates for savings in these categories appear in the residential sector $b_{\text {With Industrial Audits }}$
} 
TABLE 80

Industrial/Agricultural and Utility

Conservation

\begin{tabular}{|c|c|c|c|c|c|}
\hline Policy & Jersey & New York & Pennsylvania & Virginia West Virginia & Total \\
\hline Energy Advisory Ser. & & 34.3 & & & 34.4 \\
\hline $\begin{array}{l}\text { Agricultural Esten- } \\
\text { sion Service }\end{array}$ & & 1.5 & a & & 1.5 \\
\hline Utility Efficiency & 5.4 & 17.0 & & & 22.4 \\
\hline Boiler Efficiency & 22.7 & & & & 22.7 \\
\hline Waste Oil Recycling & 0.8 & & 1.03 & & 1.11 \\
\hline $\begin{array}{l}\text { Tank Fuel Evaporation } \\
\text { Limits }\end{array}$ & 8.6 & & & & 8.6 \\
\hline $\begin{array}{l}\text { Load Management } \\
\text { (Utility) }\end{array}$ & & & & 0.65 & 0.65 \\
\hline Gross & & & 156.88 & 31.62 & 188.5 \\
\hline TOTAL & 37.5 & 52.8 & 159.91 & 32.27 & 280.48 \\
\hline
\end{tabular}

aso Estimate 
TABLE 81

Transportation Conservation

Policy

Right Turn on Red

Van pool, Car pool

Transportation System Management

Vehicle Inspection

Speed Limit

Promotion of Public Transit

Bus Replacement

Drag Reduction Devices on Trucks

Efficient State

Vehicles

Drivers Education

TOTAL

No Estimate
New Jersey New York Pennsylvania

0.6

0.7

0.3

5.05

10.2

6.2

19.1

16.3

0.032

0.2

1.0

0.14

17.44

0.27

14.2

36.2

39.122

7.24

0.03
0.832

0.14

17.71

96.192

1.98

18.03

10.2

9.3

37.4

0.2

1.0 
TABLE 82.

Cross Sectoral Conservation

Policy

State Procurement

Practices

Energy Outreach

Services

Ut1lity Conservation

Investment Financing

Natural Gas

Conservation

No F111 Agriculture

Solld Waste Disposal

TOTAL

aNo Estimate
New Jersey New York Pennsylvania Virginia West Virginia Total

$\begin{array}{llllll}0.35 & 1.3 & 0.14 & 0.62 & 1.3 & 3.71\end{array}$

33.6

5.8

39.4

0.5

0.5

a

0.58

0.58

0.22

0.22

2.1

2.1

0.35

35.4

0.14

2.94

7.68

46.51 
Conflicts, where present, seem to occur at some point where voluntary conservation measures developed through demonstration, self-help and education programs give way to economic incentives such as consumption taxes and price increases and regulatory practices such as thermal and lighting efficiency codes, speed limits and individual metering in multi-family dwellings. Many of the conservation activities developed under the FEA program will require legislative approval and such political forums have, in the near past, not approved several of the programs suggested in the state conservation plans.

De1 aware

The state has backed into several forms of conservation activities as a result of its fiscal crises. Among the dual purpose measures proposed in Gov. du Pont's State of the State address (proyiding reyenue for the state while cutting down on energy consumption) are a two cents per gallon tax on gasoline and winter/summer schedules for state museums.

\section{Maryland}

Among the inftlatives which have generated controversy in Maryland are (1) a recommendation by the Energy Policy Office that the state increase the direct tax and impose the state sales tax on gasoline, and (2) conservation legislation tied indirectly to insulation standards and bullding codes. HUD grants under the Energy Policy Act (for inspection training and enforcement) are conditioned on the adoption of such measures.

\section{New York}

The New York Energy Kesearch -and Development Authority has initiated a research program to develop a model energy conservation program for state schools. The agency plans to matrh usage with operating budget.a and potential buvingo through conservation programs.

In a not totally unrelated proposal the State Board of Regents is considering closing public schools in the state for five weeks next winter. Supporters contend that the plan, which w1ll close schools from Dec. 24 to the 
end of January--would save fuel costs and prevent accidents during the winter. Opponents contend that the plan would not produce significant savings and will have a harmful effect on educational programs.

Ohio

Ohio is considering legislation on many issues. Two proposed conservation measures would require businesses to close on Sundays and provide a loan for low income groups for retrofitting with insulation. The state did pass legislation (S299) which gives the Board of Bullding Standards authority to formulate and adopt, among other things, standards relating to energy efficiency.

\section{Pennsylvania}

The Governor's Energy Council in Pennsylvania has prepared a comprehensive Energy Conservation Policy which recommends the following activities (among others):

The implementation of recycling and resource recovery in both public and private sectors;

The revision of building codes to require that building designs incorporate energy conservation techniques and performance'standards;

Legislation exempting purchases directly related to' energy conservation programs for the state sales tax;

The incorporation of energy impact concerns into state developed land use plans;

The prohibition of mass metering in new apartment complexes;

The examination of an exise tax on the purchase of automoblles according to fuel efficiency.

\section{Virginia}

Governor Godwin has proposed a bill accepted by the House Committee on Corporations, Insurance and Banking and sent to the full House (Feb. 25, 1977). The bill authorizes the Housing Development Authority to supervise 
federal loan assistance (no state funds will be dispensed) to persons who want to install insulation, convert to a more economical heating system, install solar energy equipment, or install storm windows and storm doors.

The Virginia Energy Office has initiated a Winterization Program to provide training to local agencies in the installment of thermal insulation, storm windows, etc. These agencies in turn will winterize homes of low income and elderly people in the state.

\section{Virgln Islands}

Because of 1ts unique energy consumption pattern, economy, climate and stnall population traditional energy conservation measures exemplified in, for example, the FEA Conservation Program seem destined to have negligable benefits for the 1slands. At least two programmatis requircments du uul seem appilicable: islanders drive on the left side of the road thus the right turn on red cannot be effected, in addition heating degree days are zero because of the climate thus thermal efficiency and insulation standards would be detrimental (some economic cost for conversion but no induced energy savings). Because of the small share of energy consumed in the residential, commercial and transportation sectors the three remaining mandatory conservation measures in the FEA program w111 provide only a small percentage of the minimum reduction in energy consumption by 1980 required for participation in the FEA program. In fact to reash the $5 \%$ reducilon through conservation from the residential, commercial and transportation sectors alone would require a $47 \%$ reduction in profected energy use, which is, according to data in the Virgin Islands Conservation Plan, less than the current level of consumption in these sectors.

This appears impractical and the conservation program drawn up by the V1rgin Islands calls for a $5 \%$ savings goal acroso all consuming sectors. As shown in Tahie (83) this would mean that azch consuming sectur w111 conserve an amount of energy proportional to projected consumption and that the major industries w1ll be the major conservators. 
TABLE 83

Savings Goals by Sector in the Virgin Islands

Sector

Oil Refining

Other Industry

Electric (WAPA)

Other (Res., Comm., Trans.) Total

\section{Projected Consumption (10 12 Btu)}

103

5.63

7.52

13.75

129.94
$5 \%$ Savings Goal $\left(10^{12} \mathrm{Btu}\right)$

$$
5.15
$$

.28

.38

.69

6.50 
UTILITY REGULATION, RATES

The regulation of rate increases and utility pricing practices is of continuing concern throughout the region. The short term radical increases of emergency fuel prices over the winter are not at issue, rather the continuing periodic escalation of electric and gas prices moves consumers and politicians to take action. Among the state initiatiyes are; actions to regulate. utility pricing (generally through the restriction of factors to be included in the rate base--for example utility advertising practices); changes in the rate structure designed to encourage commercial and industrial conservation while not penalizing residential consumers; consumer protection by regulating utility activities (life-line bills have been introduced in every state which suffered fuel shortages over the past winter) and; providing for improved consumer representation at utility hearings.

Such activities are not without controversy. In Delaware a lifeline bill got little support in the legislature last year. A new bill is being introduced this year and is expected to attract increased attention. Delmarva Power and. Light Co. regards the lifeline concept as "energy welfare" and says the costs would be borne by other customers. Maryland (H17) prohibited the inclusion of lobbying expenses in rate bases and Ohio (S94) limited construction work in progress to those facilities at least 75 percent complete and further sald it can never exceed 20 percent of a utility's valuation. Public Service Electric and Gas has received permission from the New Jersey. Board of Public Utility Commissioner to institute a peak load pricing experiment which Commissioner McGlynn said "has the potential to foster cunservation.... while giving people a choice based on costs, and glvae them more conlirul over the size of their utility bills."

In New York consumer advocates are concerned with the new procedures established by the PUC: partles opposing rate increases must rely on a process known as "discovery" rather than the usual technique of crossexamination to obtain information needed to complete their case. Consumer advocates feel the new procedures impede effective intervention by inexperienced and unsophisticated intervenors. 
Chapter VI The Actors
A. The Governors
B. State Agencies (with Appendix A)
C. State Legislatures
D. Regional Groups
E. The Utilities
F. The Industries 
The Governors

Delaware
Maryland
New Jersey
New York
Ohio
Pennsylvania
Virglnia
West Virginia
Puerto Rico
Virgin Islands

Pierre S. du Pont

Blair Lee III (acting, see Maryland)

Brendan T. Byrne

Hugh L. Carey

James A. Rhodes

Milton J. Shapp

Mills E. Godwin

Julıı D, Ruckfelier IV

Carlos Romero Barcelo

Cyril E. King

The past year has been one of change in most states. Shifting priorities have resulted from the recession, from the severe winter, from fiscal problems in the states, from changes in state governments, and from anticipated changes in national energy policy. Indications of specific programs and the drift of the states policies are available from the Governors' State of the State messages: Delaware

Governor Pierre S. du Pont

March 3, 1977

"Delaware's budget $1 \mathrm{~s}$ awash in a $\$ 56$ million sea of red ink and facing a potential deficit of $\$ 65$ million for the upcoming fiscal year beginning July 1 st......."

"I am proposing today a three point program to rescue Delaware from bankruptcy, to stabilize our finances, and to do so in a way which will begin our economic recovery, provide jobs for Delawareans, and reverse the declining competitive situation of our state:

"First, we must promptly pay off the $\$ 56$ million deficit.....

"Second, reducing next year's $\$ 65$ million deficit by cutting the cost of state government $\$ 40$ million.....

"Third, to solve the remaluing defic1t, I propose to expand the tax base....." 
Among the specific measures Gov. DuPont proposes implementing are the following:

increasing auto registration fees;

increasing auto document fees;

raising gasoline taxes by two cents per gallon;

increasing mercantile taxes an average of 15 percent;

that State museums go to a winter/summer schedule and charge nominal fees;

that the Department of Natural Resources increase user fees;

raising the corporation income tax by $21 \%$, from $7.2 \%$ to $8.7 \%$ on

corporate profits, and;

the reparation of inequities forced upon the states by the Federal government.

Maryland

Governor Marvin Mande1

Jan. 19, 1977

On August 23, 1977 Governor Mandel was found guilty of a scheme to use his office for personal profit. On August 25 Attorney General's opinion advised that Lt. Gov. Blair Lee III would remain acting governor until Mandel exhausts all appeals and that Mandel will forfeit his office but not his title after sentencing on Oct. 1. (State Headlines, the Council of State Governments, Sept. 2, 1977).

In his State of the State address Governor Mandel noted that the Board of Revenue calculated that General Fund revenues available for funding next year.... would be $\$ 9$ million less than current spending. Despite this expenditures are anticipated to increase. To meet anticipated obligations the Governor asked the General Assembly to raise $\$ 175.8$ million in new General Fund Revenues and $\$ 44 \mathrm{million}$ in Special Fund Money. To raise these funds the Governor has proposed an increase in the sales tax (from four to five percent), an increase in the Motor Vehicle Titling Tax (from four to five percent), and a change in the law governing the use of proceeds from the state lottery.

Also Included in the Governor's message was a proposal to allocate $\$ 4.6$ million to support abandoned rall lines in the State, most of them on the eastern shore. 


\section{New Jersey}

Governor Brendan Byrne

January 11,1977

In his address Governor Byrne stated that New Jersey lagged behind the rest of the nation in recoving from the recession of 1972, that this lag reflected major problems in the State's economic structure--particularly its manufacturing sector, and that the embargo triggered recession in 1974 left the State with a badly damaged economy that would acquire years to repair.

To assist in resolving unemployment and economic problems the Governor:

Urges swift passage of legislation arming the Economic Development Authority with powers to designate urban growth zones, to promote their economic development, and to consider the actual development by EDA of urban industrial parks;

Has played a major role in developing the CONEG agenda whose centerpiece is the proposed Regional Energy and Development Corporation;

Proposed the creation of a Public Transit Agency within the DOT to centralize the regulatory functions now performed hy the Commuter operating Agency and the Board of Public Utilfty Commissioners, and;

The creation of a State Science Advisory Councll to provide expert assistance on the complex scientific related questions facing many state agencies.

Governor Byrne is also submitting other types of energy related actions:

A Bill which will enable the PUC to institute a lifeline Rate Structure for gas and electric, as well as telephone services, with the cost to be borne by the existing tax on the gross recelpts of public utilities;

Legislation which will provide a cap on the yleld from the tax to the municipalities in which generating installations and other utility installations are located, and;

A program to assure the future of the Pine Barrens and the huge underground reservolr of water below them so essentlal to New Jerseys future. 
New York

Governor Hugh L. Carey February 3, 1977

In his State of the State message to the legislature, Governor Carey of New York outlined the following energy related initiatives, actions and findings:

- The Governor will make recommendations on the expenditure of approximately $\$ 600$ million by the Port Authority of New York and New Jersey for the revitalization and improvement of mass transportation facilities in the State;

-That it is the legitimate function of Government to rescue the ocean and lake ports of the state and prevent the deterioration of the railbeds upon which its goods are carried. To carry out such actions (among others) Gov. Carey proposes a $\$ 750$ million capital Develop Bond Issue be placed on the ballot next November.

-Centra1 to New York State's economic vitality, is an adequate and economical energy supply. To ensure this the Governor is working at the national level to assure that the emerging energy policy is sensitive to the particular and pressing situation facing the State; at the regional level to further the proposal for a Reglonal Energy and Development Corporation, and; at the State level to develop a comprehensive energy policy, to develop spectfic energy management measures and to develop drilling potential in Lake Erie;

-To assure that the regulatory processes of the Department of Environmental Conservation fulf 111 their intended objective without costly delays the Governor is recommending standardized procedures in the review of permits, 1lcences and other applications, Including specifying time limits for public comments and strict criterla for determining whether or not a public hearing will be held, and;

-The Governor is also submitting legislation to create a Division of Consumer Advocacy and provide for consumer representation on State licensing Boards. 
$\underline{\text { Ohio }}$

Governor James A. Rhodes

January 12,1977

In his address to a joint session of the General Assembly Gov. Rhodes made the following points:

"To reduce that cost to the consumer (of the debt incurred in building energy generation facilities) I have asked the Director of the (Ohio) EPA to develop with the water and air authorities a program for financing the construction of energy facilities."

"The moot valuable and abundant twel to us in ohin is coal."

"We have urged 'U.S. ERDA to allocate $\$ 100$ million to develop shale gas in Ohio and neighboring states' and I will continue my efforts... in urging the Federal Government to develop the vast deposits of shale gas....'"

"To encourage the increased use of alternate fuels I will propose that industrial and commercial users of natural gas be provided a tax exemption for the facilities necessary to convert to alternative fuels."

"I will also submit for your consideration a bill to amend existing Yort Authority legislation to encourage private development of ports along the Ohis River."

"I will propose legislation to require that all bills introduced in the General Assembly contain a cost Impact statement."

\section{Virginia}

Governor Mills E. Godwin January 17,1977

"We began in 1974 in tho midot of dil ellesgy shortage, reminding us that even America has her limitations, which Virginia herself could not escape. Here our perspective has changed from the need for imncdiate action to longer range planning for conservation and greater self-sufficiency."

"As the great migration from the farm to the city and out into the suburbs began to wind down under the impact of new industries in rural areas, there has been emerged the growing problem of mass transit. The perplexing problem of Metro Rail likewise remains."

"Perhaps the most traumatic and persistent problem in all my years of public life has been the contamination with toxic poisons of the 
historic James River..... and the Chesapeake Bay. Circumstances still demand the continued closing of the James River."

"Actual revenue collections during the first quarter of the current biennium and revised estimates for the remainder of the biennium project a shortfall in revenue of $\$ 219.5$ million from State sources. I am glad to report that as a result of further savings and adjustment the gas (between revenues and expenditures has been lowered to $\$ 102.6$ million."

West Virginia

John D. Rockefeller IV February 16, 1977

"Since coming to this office, I really think that I have spent more time in dealing with the energy crisis that $I$ have in any other function in the ordinary conduct of government."

"Natural gas has been in dangerously short supply. I think that you are probably aware of that in this chamber. And I might say that the curtailment of heat in this chamber and the other chamber was not the idea of the governor, but was the idea of the Columbia Gas System. 0il and petroleumbased fuels have been critically scarce in recent weeks."

"Is it any wonder then that we pin our hopes for a healthy economy upon coal--coal, which is the touchstone of prosperity for this state?"

"My administration will foster and assist the coal industry in attaining higher levels of productivity and profit. In return, I expect the coal industry to protect the safety and welfare of our miners and to abide by strong regulations to keep our land, our water, and our air unspoiled."

"Coal may be the base of our economy, but it in fact is too narrow a base for the whole state. Any West Virginian who lived through the fifties and Sixties can vouch for that."

"I have developed a major job-creating program and will deliver to you in this first session the beginning element of that program..."

"My budget proposes a state-community partnership grand fund. The state's share of 25 percent w111 go in outright grants to communities for the tools for economic and community development in such areas as water 
systems, sewer systems and other basic services. When added to the many federal dollars in a variety of federal programs, they will set the stage for a new era of economic growth."

For this program, I ask the sum of $\$ 10,000,000 \ldots$.

"Now in addition to the $\$ 10,000,000$ grant program, I also am seeking an additional $\$ 6,000,000$ for a low-interest revolving loan fund to help localities to by land and to develop land for industrial and commercial purposes, and to build thereon plants and facilities for new industrial tenants..."

"I am well aware that the state is suffering through the hardest winter in memory, and I have asked the Department of Highways to estimate funds which can be spent on projects for immediate relief..."

"For these weather-related programs, $T$ am asking a oupplemeulal appropriation of $\$ 10,000,000$ for fast repair service and an early start on resurfacing our highways. I request that this money be made available at once, so that emergency patching and repairs might begin just as soon as the weather breaks..."

"Our state is not only capable of riding out the current crisis--it actually can benefit from it, because West Virginia is the nation's safe deposit box in the energy bank of the world."

"I can furesee an ever-increasing demand for our coal resources as being the key to a national energy policy."

"And I shall make my own voice heard--not only across this land, but throughout the wor1d--in telling all peoples that we here, in fact, in Appalachia and in West Virginta may have the real answer to a global crisis."

"In our Department of Mines, T expect strong leadership Lu Lmprove and expand our program of minc anfety inspuctiono."

"The tragedies of the past simply must not be allowed to be repeated. A state government which zealously defends the safety of the mines as its prime objective--that is my goal. And I ask full funding of the budget request for this department..." 
Puerto Rico

Governor Carlos Romero Barcelo February 24, 1977

"In the four years following 1972, Puerto Rico fell into a deep economic crisis which is manifested in an oppressively high unemployment leve1, in persistent inflation, in a decrease in the influx of capital investment funds, in diminished real production by our economy, in a decrease in real family income, in a spiraling increase in our public debt..."

"During fiscal year 1975-76, the rate of growth of our gross product held to its declining trajectory, from $6.6 \%$ in $1974-75$ to $4.8 \%$ in $1975-76$, at current prices, or $1.2 \%$ after subtracting the effect of inflation..."

"The losses accumulating steadily in the sugar industry confront us at this moment with a staggering \$232-million in financial obligations. Estimates indicate that, at this rate, the current harvest will saddle us with an additional deficit of $\$ 62.6 \mathrm{million}$. I have ordered that an in-depth study be undertaken to find ways of cutting back our losses as quickly as possible, and to set forth long-range options for dealing with this situation...."

"Because the government's capacity to appropriate funds predicted upon anticipated future income has been exhausted, we are obligated at this time to meet commitments amounting to more than $\$ 527$ million of which $\$ 230$ million must be obtained in the immediate future. A large portion of this obligation will weigh onerously on the next budget which I shall submit to you, and will thus limit our ability to designate how the income of the government will be utilized...."

"I propose that we dedicate this first legislative session to putting our financial house in order, to correcting the most flagrant inequities and to inaugurating our government program with a firm step and a clear sense of direction...."

"One area of concern to the consumer is the rising cost of the energy that serves a multiplicity of daily functions in all of our lives. We urgently need an energy conservation policy based on the maximum utilization of natural energy sources and a decreasing dependence upon fossil fuels. 
I am proposing legislation to redesignate the Office of Petroleum Derivatives as the Energy Sources Development Office, and to give it responsibility for devising a broad and ambitious long-range plan which will anticlpate our future needs and make adequate provision for supplying the resources our development will require. In the meantime, we shall go forward with studies and other pertinent activities related to the question of possible petroleum deposits within our island...."

The Virgin Islands

Governor Cyril E. King February 8, 1977

In his State of the Territory address this year Gov. King announced that a majority of the austerity measures (proposed the previous year) had been implemented, including a Petition for Federal Assistance a suit to secure the return of certain oll customs duties and gasoline taxes retained by the Federal government, and initiating discussions with Hess Oil to modify 1 ts present tax incentive arrangement with the territorial government. In addition Hess $0 i 1$ and the V.I. Government had reached agreement on the containerport for the south shore of St. Croix.

The Governor also proposed a series of actions designed to encourage and provide for increased tourism and industrial development. Such actions would include compaigns to attract. sperifte industries; the crcation of an industrial park system, the eventual establishment of financial incentivas to attract industry, modification of the Industrial Incentive Development Act, and improvement of mainland tariff provisions to facilitate the duty free entry of products manufactured in the Virgin Islands.

Also noted was action on the Coastal Zone Management Program designed to provide clear quidelines for the orderly development and preservation nf a11, goastal aroac. 


\section{State Agencies}

Following on the energy crises of 1973-1974 most states created energy organizations to implement the state allocation program and in many cases coordinate energy planning and policy analysis. With the possible exceptions of the Governor's Energy Council in Pennsylvania and the State Energy Policy Office in Maryland, few of these agencies continue under their original mandate. In several cases follow on legislation has been passed which enhances and expands the original mandate of the initial energy office (for example, The State Energy Office created in New York in 1976 increased the scope of authority of the original Emergency Fuel office), in other cases the original energy responsibilities have been delegated to or been attached to another state agency; in Delaware most energy planning and analysis functions have been shifted to the Office of Management Planning and Budget; in New Jersey the State Energy office was attached to the Department of. Public Utilities by Executive Order.

The maneuvering surrounding the creation of the State Energy Office in New York extends back to the Harris-Padayan Bill of 1275. wiblch proposed an agglomeration of all existing energy related powers in one office. Though this proposal was defeated, legislative recasting produced the Haley-McFarland Bill of 1976 which provided an energy policy emphastzing conservation, alternate energy resources, and a review of executive and municipal operations for compliance with state policy. The Bill also created an Energy office with a variety of regulatory, planning and policy functions. The Governors staff, which had been maneuvering for the creation of an office free of legislative interference, suggested that with certain amendments, the Governor was willing to accept the bill. The B11I, as passed and signed, created an office with no state approprlation, making it dependent on federal grants over which the Governor has complete control. In addition, many of the functions of the office were made permissable rather than mandatory, the language changed from "sha11" to "may".

Simllarly in New Jersey both houses of the legislature, over Governor Byrne's opposition, cleared a bill which would remove the State Energy office from under DPU authority and place it in under. the State Attorney 
General. According to newspaper reports Joel Jacobson (President of the Public Utility Commission) advised the Governor to veto the Bill. Subsequently legislation creating a cabinet level energy department cleared both the house and senate and was signed into law in July, 1977. The Bill disbanded the PUC and made it a subdivision of the new department, required that the new department develop a state master energy plan, that the department report to the legislature on the energy functions of other state agencies and gave the. new department co-extensive jurisdiction over energy facility siting às well as requiring a variety of other energy related activities. Joel Jacobson was appointed to head the department.

Each state in the region differs in its allocation of energy responsibilities among executive agencies. Appendix A outlines the major state energy agencles with energy related functions. Though they conform, roughly, to an existing division of functions (energy, environmental, utility regulation, transportation, labor and industry, and communtry development) there are varlations between States. For example, with the exception of New York (N.Y. State Energy Research and Development Authority), Pennsylvania (the Pennsylvania Science and Englneering Foundation), and Ohio (the Energy Resources and Development Agency) the states do not have agencies exclusively oriented to supporting extensive technical research. In Ohio and Maryland environmental regulation is split between two agencies (the Environmental Health Administration and the Department of Natural Resources in Maryland, and the Department of Natural Resources and the Environmental Protection Agency in Ohio) while in other states such powers accrue to single agencies. In Delaware and New York the transportation departments regulate common carriers, in most other States this is dune by the utilities departments.

The existence of agencies with overlapping or complimentary iespunsabilities means that in considering specific development or regulatory actions several (or many) agencies participate. Table 84 shows some of the agencies which particlpate in a variety of activities at the state level, though the form of particlpation vartes. For example, the Governor's Energy Council in Pennsylvania is the lead agency in developing a coordinated energy conservation policy and program. Other agencies such as the Department of Transportation and the Public Utility Commission are the 
lead agencies in developing program options which fall in their bafliwick (say mass transit and rate structure incentives respectively).

Just as at the federal level, at.the state level there are conflicts between agencies with complimentary activities but conflicting responsibilities. In its five year existence the New York State Board on Electric Generation Siting and the Environment (composed of members from the PSC, the DEC, the Department of Health, the Department of Commerce, and one resident of the judicial district in which the facility is to be sited) has failed to approve the siting of any new power plant. In addition the actions of state agencles are often circumscribed by overriding federal legislation or regulation and by federal funding support. Dissension between federal agencies is often mirrored by executive agencles at the state level. The lack of continuity in federal funding has given rise to actions which would require state legislative review of federal flowing to state government. 
TABLE (84) Participarts in Energy Related Activities

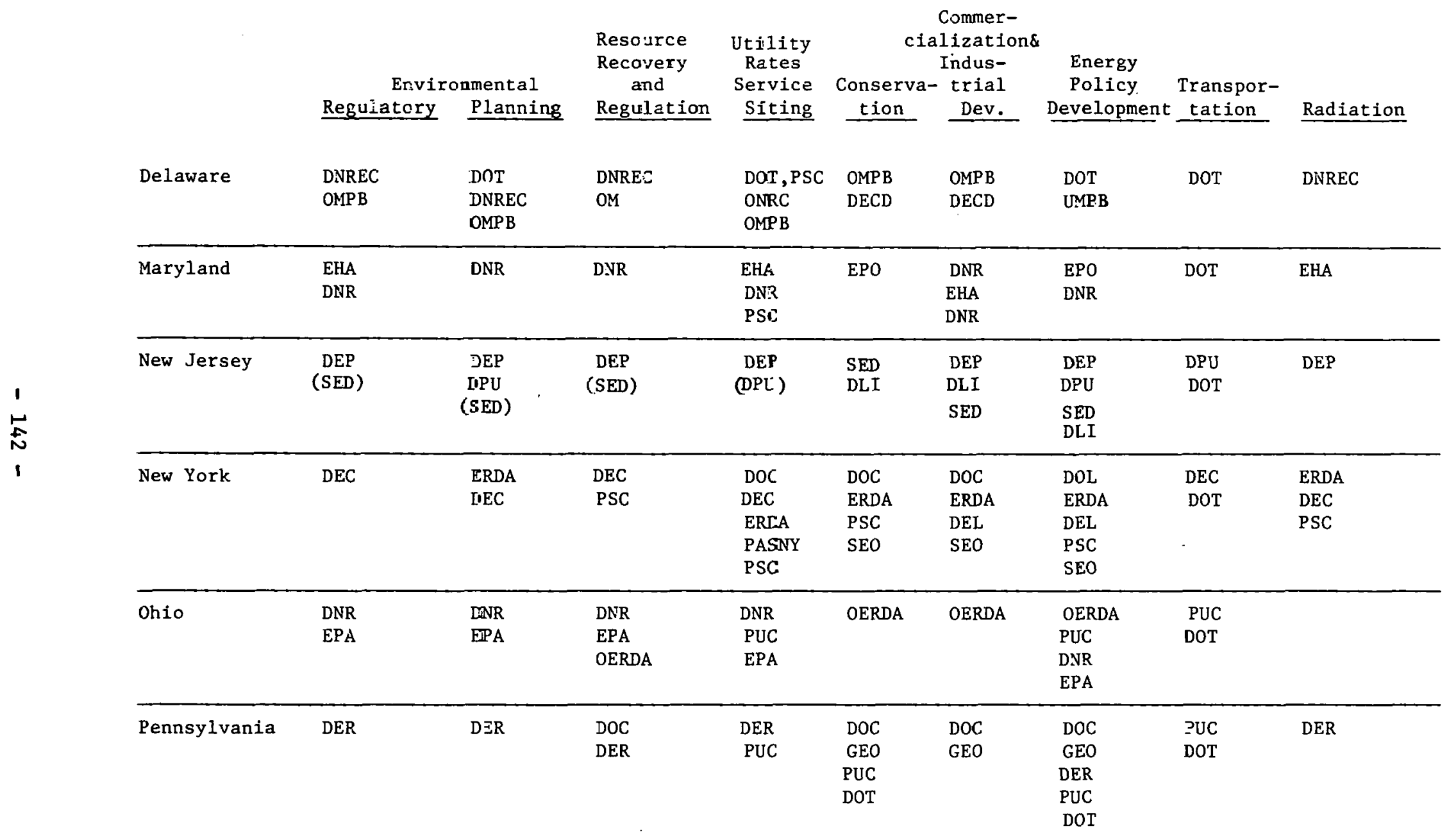

Source: Derived from activities shown in Appendix A. 


\section{State Legislatures}

Despite fiscal crises and elections the past two years have seen an Increasing commitment to participation in energy affairs on the part of state legislatures. While the orientation of effort differs, a few observations may be made:

-Conservation, alternative resources, and solar legislation seem to provide the basis for positive legislative energy policy. Most leglslatures have passed, or have under consideration, several bills in each of these categories. However, no state has passed comprehensive policy oriented bills in any of these categories, their approach is, to date, piecemeal;

-Perhaps the bulk of legislation passed or under consideration relates to utility regulation, rate bases and structure, conservation, and consumer protection. Of particular interest following the severe winter is "life-line" legislation which has been introduced in almost every state and conservation legislation necessary to implement the policies and activities developed under the FEA sponsored conservation program, and;

-The coastal states are concerned with the potential undesirable impacts of fossil fuel facillties and are moving to increase existing regulations to protect against impacts stemming from OCS development, increased coastal traffic, and the uncontrolled use of shoreline. 


\section{Maryland}

House Environmental Matters Chairman: Rep. John Arnick (Staff: John Szymansk1, 301-269-2363

Senate Economic Matters Chairman: Sen. Harry McGuirk

(Staff: W. Porter Ellington 301-269-3296)

Senate Budget and Taxation

Chairman: Sen. Roy Staten

(Staff: Gene Burner, 301-269-3542)

$$
\begin{aligned}
& \text { Address: State House } \\
& \text { Annapolis, MD } 21401
\end{aligned}
$$

New Jersey

Assembly Agriculture and Environment

Chairman: Assm. Donald Stewart

(Staff: Michael Catania, 609-292-9106)

Assembly Energy and Natural Resources Chairman: Assm. John Froude

(Staff: John V. Helb, 609-292-9106)

Senate Energy and Environment

Chairman: Sen John Russo

(Staff: David Mattek, 609-292-9106)

Senale Agriculture

Chaliman: Sen. Raymond Zane

(Staff: Norman Miller, 609-292-7734)

$$
\begin{aligned}
& \text { Address: State House } \\
& \text { Trenton, NJ }
\end{aligned}
$$

New York

$$
\begin{aligned}
& \text { Senate Corporations, Authorities and } \\
& \text { Public Utilities } \\
& \text { Chairman: Sen. James McFarland } \\
& \text { (Staff: David Blavey, 518-472-6084) }
\end{aligned}
$$


New York (Cont'd)

Senate Consumer Protection

Chairman: Sen. Joseph Pisani, 518-472-2127)

Senate Conservation, Recreation and Environment

Chairman: Sen. Barnard Smith

(Staff: Joseph Martino, 518-472-2167)

Assembly Corporations, Authorities

and Commissions

Chairman: Assm. Irwin J. Landes

(Staff: Lawrence 0'Toole (518-472-3050)

Assembly Consumer Protection and Affairs

Chairman: Seem. Harvey Strelzin, 518-472-3800

Assembly Environmental Conservation

Chairman: Assm. G. Oliver Koppell

(Staff: Milton Amgott, 518-472-3040)

$$
\begin{array}{ll}
\text { Address: } & \text { State Capitol } \\
& \text { Albany, NY } 12224
\end{array}
$$

Ohio

House Energy and Environment

Chairman: Rep. Thomas Carney

(Staff: Robert Yaekle, 614-466-7977)

House Insurance, Utilities and

Financial Institutions

Chairman: Rep. William Hinig

(Staff: Michael Lepp, 614-466-7850)

House Agriculture and Natural Resources

Chafrman: Rep. Dale Locker

(Staff: Thomas Altherr, 614-466-7977)

Senate Energy and Utilities

Chairman: Sen. Neal F. Zimmers, Jr.

(Staff: Richard Dreese, 614-466-4977)

Senate Conservation \& Environment

Chairman: Sen J. Timothy McCormack

(Staff: John Bay, 614-466-4977)

Address: State House

Columbus, Oh10 43215 


\section{Pennsylvania}

House Mines and Energy Management

Chairman: Rep. Bernard O'Brien

(Staff: Mr. George Ellis, 717-787-2634)

Senate Environmental Resources

Chairman: Sen Robert Mellow

(Staff: Elaine Brazil, 717-783-1216)

Address: Main Capitol Bldg.

Harrisburg, PA 17120

\section{Virginia}

Assembly Conservation and Natural Resources

Chairman: Rep. John Gray

(Staff: Susan Gill, 804-786-3591)

Senate Agriculture, Conservation \&

Natural R.ecouroeo

Chairman: Sen. Howard Anderson

(Staff: Susan Gill, 804-786-3591)

\section{Address: State Capitol}

Richmond, VA 23219

\section{West Virginia}

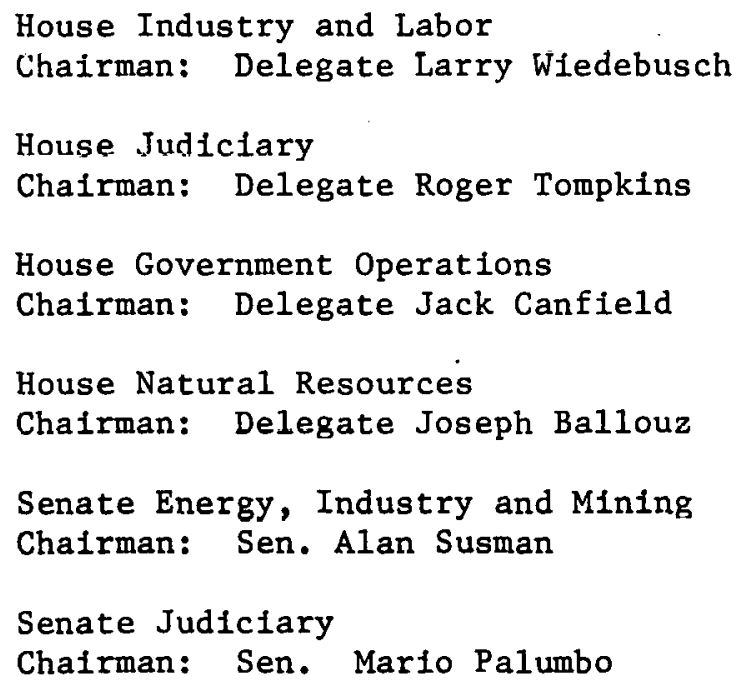


Puerto Rico

\section{Contact: Office of Legislative Services Capito1 \\ San Juan, Puerto Rico 00901 \\ (Telephone 809-725-5200)}

Virgin Islands

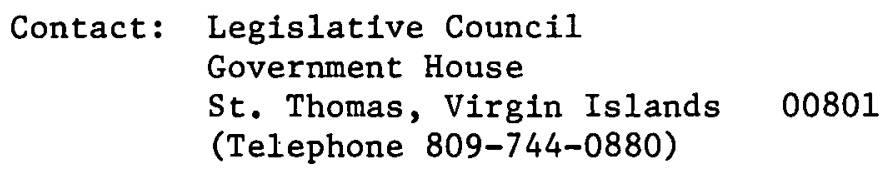


Examples of Legislation Passed in 1975 and 1976

Fossil

N.Y. Chap 892 (1976) Authorizes regulation of liquid natural gas facilities by DEP.

N.J. Spill Compensation and Control Act, Jan. 6, 1977 sets procedures for. liability prevention control and compensation in cases of oil spill.

Pa. Act 103 (H.796) Amends Land and Water Conservation and Reclamation Act to allow State personnel to enter private land to investigate possible pollution from mining: permits emergency expenditures.

Md. Coastal Facilities Review Act (May, 1975) mandates permits for construction of facilities related to crude oil and natural gas in areas adjacent to the Atlantic Ocean and Chesapeake Bay.

Nuclear

N.Y. Chap. 641 (A. 7761-B) grants Comnissioner of the Department of 'rransportation authority to premulgate regulations with respect to transportation of hazardous materials, including radioactive.

Solar

Md. Hi604 (1976) Requiring that snlar energy heating and cooling unils used In cercaln buildings be assessed in a manner so as to not exceed the assessment of conventional heating and cooling units.

Ohio JR88 (1976) directs the Administrative Service Department to examine the possibility of using snlar energy for heating office factlities.

Va. Chap. 331 (1975) creates a solar energy oenter to serve as a clearinghouse for general and technical information on solar energy.

\section{Conservation}

N.J. Chap. 46 (1976) Right Turn on Red

N.Y. Chap 948 Right Turn on Red 
N.J. State Uniform Construction Code (Oct., 1975) empowers the Commissioner of the Department of Community Affairs to promulgate a Statewide building code: including an energy subcode.

Del. H.R.102 (1976) requests Del. Society of Professional Engineers to study relating to efficiency of space heating and cooling equipment within all state owned building.

Ohio S299 (1976) gives the board of building standards authority to formulate regulations related to, among other factors, conservation of energy.

Utility Regulation

N.Y. Chap 556, $1976(8.10675)$ authorizes PSC to order outside audit of public utilities every 5 years, audits to be paid for by utilities.

$\mathrm{Pa}$. Act. 215 revises PUC rate case and consumer cut off procedures and regulates contracts between utilities and affiliated interests.

Pa. Act 145 (s.1219) requires public utilities to file annual conservation reports.

Del. . Bill S7 (May 1976) requires public hearlings on all applications to change the fuel adjustment rate.

Va. S.499 (1976) same as Del. (B111 57)

Md. H220 (1976) mandates the study of alternative rate structures. H17 (1976) prohibits the inclusion of lobbying expenses in rate bases.

Ohio S94 (1976) created separate office of advocacy to represent consumer at electric rate hearings and other proceedings.

\section{Siting}

Pa. Senate Concurrent Resolution 238 directs State Commission to study energy facility siting and report, with draft legislation by March, 1977. 
Institutiona1

N.Y. Chap. 819, 820, 821, 1976 three bill package establishing Energy Iraw and creating a State Energy Office.

$\mathrm{Pa}$. Act 216, makes Public utility commissioners full time, provides for appointment of administrative law judges, establishes various bureaus.

Del. H137 (feb. 1975) removes the oil depletion allowance as a dedurtion nn hoth State corporate and personal taxes. 
$\underline{\text { Regional Groups }}$

To all intents and purposes the states participating in this ERDA public meeting lack a strong regional identity. There are compact organizations whose members are drawn entirely or in part from the region (the Delaware River Basin Commission is one example of the former, the Appalachian Regional Commisssion of the latter). However, in most cases a stronger regional identity is obtained from smaller groupings of states with similar problems or resources: for example, coal producing states with the Appalachian Regional Commission; river basin states with specific river basin commissions, and; those states bordering the New York Metropolitan area with the Tri-State regional planning commission.

That is not to say that regional agencies have little impact. Quite the opposite, they may significantly benefit those states which are a part of their region. The Appalachian Regional Commission has funding capabilities which, linked to its energy program, promises significant benefits for the States. The ARC's energy work is concentrated in four major areas, as listed below:

I. Resources, Markets and Environmental Impacts

A A. Energy Supply and Demand

B. Energy Research and Development

C. Assessment of Western Coal Development

D. Devonian Shale; Coal Seam and Similar

E. NASA Project

F. Assessment of the Impacts of Energy-Related Technology (joint w1th EPA)

G. Natural Hazards

II. Public and Private Controls on Energy Decisions

H. Regulatory Powers

I. Environmental Procedures

J. Energy Dectsion Making in Appalachia

K. Assessment of Public Energy Policies in Appalachia

III. Trnasportation

L. Coal-Haul Roads

M. Regional Energy Transpnrtation

N. Coal-Marketing Options 
IV. Impacts of New Energy Facilities

0 . Siting of Energy Facilities

P. Energy-Related Capital Requirements

Q. Linkages between Environmental Problems and Human Health in Appalachia

R. Impacts of Energy Technology on Water Supplies and Quality

S. Energy Impact Program

(ARC Meeting, March 21, 1977)

While members of the Commission have not established a general energy policy (as has been done by the New England Regional. Commisston) it appears to be growing feeling that the development of energy resources should not be constrainted solely on the basis of environmental impacts, rather energy projects should be judged in light of the range of changes incurred, including the economic and socio-economic benefits.

Two other regional organizations may have a potentially large affect in the conduct of energy affairs in the northeast, largely as a result of their political nature. The first, the Northeastern Legislative Conference was created as an experiment in regional/state legislative staffing. Its primary purpose has been to serve and supplement the needs of the region's (New England, New York, New Jersey, Pennsylvania and Delaware) legislative leadership in the area of energy policy.

The second group is the recently created Coalition of Northeastern Governors (N.Y., N.J., Pa., Conn., Mass., R.I. and Vermont). At its Saratoga Conference on Nov. 13-14, 1976 the Energy Policies Panel to CONEG made the following recommendations:

-A Northeast-Appalachian Coal Tașk Force, with participation of all member states, should be established prior to the creation of a Regional Energy Development Corporation (REDC) as a first step toward Improving our energy program. This group should be charged to begin development of a comprehensive master plan for revitalizing the coal industry in the East which will help gulde the activities of the Regional Energy Development Corporation.

-The Coalition of Northeastern Governors should press for a much stronger national energy conservation effort by: 
A. supporting greatly increased funding and accelerated implementation of energy programs authorized by Congress in the Energy Conservation and Production Act of the Energy Policy and Conservation Act.

B. urging the Energy Research and Development Administration to work with the states in developing a comprehensive research and development program for energy conservation and efficiency that would recelve a level of funding commensurate with its potential impact upon national energy policy.

-A Regional Energy Development Corporation, created under an Interstate compact, should be established to:

A. help implement the loan guarantee program under the Energy Conservation and Production Act.

B. facilitate the introduction and expanded use of financial incentives to provide capital for energy development.

C. facilitate the increased development of Eastern Coal to reduce regtonal dependence upon o11 and natural gas.

-A Regional Energy Policy Advisory Group should be established to report to the Governors on those issues, such as national plpeline location, that merit a regional response or initlative. Such a group could serve as a policy and Information resource for the new Regional Energy Development Corporation.

-The Northeast Governors should continue to strongly urge the Administration, efther directly or through the Congressional Delegation, to give high priority to resolve the health, safety and security issues of the nuclear fuel cycle so that issues like siting of power plants may be resolved.

-The Coalition of Northeastern Governors should support a national application of marginal cost pricing e.g. time-of-day and seasonal variation of rates, to utflity rate structures.

-The Coalition of Northeastern Governors should support a regional approach to reducing energy consumption via improved energy efficlency standards for bulldings, lighting, appliances and many other energy consumption activities and devices. 
-The Northeastern Governors despite continued national resistance should support legislation providing for revenue sharing from the production of ofl and natural gas on the Outer-Continental Shelf. The governors should establish a task force to determine the possible financial arrangements with the ofl companies.

-Federal and/or state income tax. credits for energy conservation and renewable resource alternatives should be instituted, financed by small increases in gasoline taxes or automobile registration fees. Further, states in the region should examine the feasihility nf adnpting a uniform property tax abatement program for energy-saving capital investment by business and industry.

-The Northeast. Governors should support efforts to allow new natural gas.prices to move toward parity with oil so long as an equitable regional distribution of price and supplies is assured.

-The Northeastern Governors should urge ERDA to improve the quantity and quality and distribution of consumer information on alternative energy systems.

Recent reports indicate that CONEG has agreed to seek legislation allowing them to form the Energy Corporation of the Northeast (ENCONO). ENCONO would sell federally guaranteed bonds and use the proceeds to stimulate energy production and conservation through loans, guarantees and grants to private industry. 


\section{Regional Organizations}

Susquehana River Basin Commission Office of the Executive Director 5012 Lenker St. Mechanicsburg, PA 17055

Delaware River Basin Commission Office of the Executive Director 25 State Police Drive (P.0. Box 360) Trenton, New Jersey 08603

Appalachian Regional Commission 1666 Connecticut Ave., N.W. Washington, D.C. 20235

Interstate Commission of the Potomac River Basin 4350 East West Highway

Bethesda, Maryland 20014

Northeastern Legislative Conference c/o Secretary of the Senate (Box 67) Capitol B1dg.

Albany, New York 12224

The Coalition of Northeastern Governors'

Room 243

State Capitol

Albany, New York 12224

The Tri-State Planning Commission 100 Church St.

New York, New York 10007

The Port Authority of New York and New Jersey

1 World Trade Center

New York, New York 10048

The Ohio River Basin Commission

36 E. Fourth St.

Suite 208-220

Cincinnat1, Oh1o 45202
Exec. Dir. Robert J. Bielo tel (717) 737-0501

Exec. Dir. James F. Wright tel (609) 883-4500

Energy Staff Hugh Montgomery tel (202) 673-7893

Exec. Dir. Paul W. Eastman tel (301) 652-5758

\section{Eugene Gleason}

(FTS) 562-4689 Acting Director CONEG Policy Research
Center, Walter T. Kicinski

Exec. Dir. J. Douglas Carro11, Jr.

Acting Executive. Director

A. Gerdes Kuhback

Exec. Dir. Col. Ike Hayes

(FTS) 684-3831 
The Utilities

In order to improve the service reliability and reduce the service cost, nearly every major electric utility system in the United States is connected with neighboring systems to form large interconnected networks and is a member of one or more electrical coordinating organizations. Depending on the participating systems, the degree of joint planning and operation of such coordinating organizations varies. In the case of a formal power pool, a contractual agreement defines each member system's responsibilities for providing operating and malntaining capacity, reserve, transmission, communication faclifties, etc. Transactions such as emergency service and economy energy transfer are important features of formal power pools. Pool members often own generating units jointly.

In the area that interests us, formal power pools include American Electric Power System (AEP), Allegheny Power System (APS), Ohio Edison Company, Ohio Valley Electric Corporation (OVEC) and General Public Utilities (the above are holding company power pools), Pennsylvania-New Jersey-Maryland Interconnection (PJM), New York Power Pool and Central Area Power Coordinating Group (CAPCO).

Among these, the New York Power Pool is in the process of implementing sophisticated pool-wide economic dispatch of power. This is the central dispatch of all sources of generation avallable to meet load changes within the pool from a single control center so that when loads increase on the whole system, the necessary increase in generation will take place on the units with the lowest incremental cost to produce the additional energy needed, regardless of where the increase occurs or ownership of the generating unit. The whole system 1s monitored at 5-minute intervals. In this way, the combined generation of the pool can be operated to meet the combined pool loads at all times at the least cost, including the cost of transmission 1osses. The New York Power Pool is one of the few power pools in the nation with such a sophisticated arrangement.

Besides power pools, most utilities in the nation, big or small, belong to one of nine regional rellability councils which are primarily concerned with improving the adequacy and rellability of bulk power supply. All 
the bulk power systems in New York are members of the Northeast Power Coordinating Council (NPCC), along with those in New England, Ontario and New Brunswick. Utilities in New Jersey, Delaware, Washington D.C., and most of Maryland and Pennsylvania comprise the Mid-Atlantic Area Council (MAAC). Utilities in the remaining parts of Maryland and Pennsylvania, in parts of Virginia, and those in West Virginia and Ohio are party to the East Central Area Reliability Coordination Agreement (ECAR) which also covers all or portions of Indiana, Kentucky, Michigan and a very small portion of Tennessee. The rest of Virginia belongs to the Southeastern Reliability Council (SERC).

It is noteworthy that in Ohio, all the rural cooperatives form a group, Buckeye Power, Inc., which owns a fair-sized generating plant and transmits its output to member cooperatives via the transmission system of the bulk power systems. Furthermore, in 1974, Buckeye Power installed a radiocontrolled system to monitor electric water heaters served by twenty of its member cooperatives. In case of emergencies, the load of the 23000 water heaters controlled by this system can be shed.

Following is a list of all bulk power utilities in the area which concerns us arranged according to the power pools and reliability councils to which they belong. 
New York Power Pool/NPCC

Centra1 Hudson Gas and Electric Corp.

Consolidated Edison of New York, Inc.

Long Island Lighting Company

New York State Electric \& Gas Corp.

Niagara Mohawk Power Corp.

Orange and Rockland Utilities, Inc.

Power Authority of the State of New York

Rochester Gas and Electric Corp.

Pennsylvania-New Jersey-Maryland Interconnection/MAAC

Atlantic City Electric Company

Baltimore Gas and Electric Company

Delmarva Power \& Light Company

*General Public Utilities Corporation

Jersey Central Power \& Light Company

Metropolitan Edison Company

Penneylvania Electric Company

Pennsylvania Power \& Light Company

Philadelphia Electric Company

Potomac Electric Power Company

Pub1ic Service Electric \& Gas Company

UGI Corporation

$\underline{\text { ECAR }}$

*Allegheny Power System

Monongahela Power Company

Potomac Edison Company

West Penn Power Company 
*American Electric Power System

Appalachian Power Company

\#Indiana \& Michigan Electric Company

\#Kentucky Power Company

Ohio Power Company

$* \star$ CAPCO

The Cleveland Electric Illuminating Company

Duquesne Light Company

*Ohio Edison Company

Ohto Edison Company

Pennsylvania Power Company

The Toledo Edison Company

The Cincinnati Gas \& Electric Comapny

Columbus and Southern Ohio Electric Company

The Dayton Power \& Light Company

*Ohio Valley Electric, Corporation

Ohfo Valley Electric Corporation

Indiana-Kentucky Electric Corporation

SERC

Virginia Electric and Power Comapny

*holding company

**power pool

\#not in the area which concerns us 


\section{The Industries}

For the area of interest, coal production is considerably more significant than that of ofl and gas and is an important economic factor in the producing states. While Ohio, Pennsylvania, Virginia and West Virginia have all three resources, Maryland tais only coal and a very small amount of gas and New York produces no coal at all.

The following is a brief discussion of these industries in terms of large produces, employments, revenues and taxes based on the latest figures available to use.

$\underline{\text { Large Producers }}$

At the end of this section, the few largest produces in each state are listed, along with their addresses. It should be noted that these are the largest produces in that particular state and no uniform criterion as to what is big and what is small is applied to all the states involved. Therefore, the largest 1isted coal producer in Maryland, for example, may have a production of only $1 / 7$ or $1 / 8$ that of a unlisted producer in West Virginia. Furthermore, this list is based on 1973 production figures and therefore may not retlect the current situation accurately. Employment

The latest employment figures we have are those of. 1974, and the number of people employed in the fuel sector (excluding processing) is not broken down into coal, oil and gas. Considering the size of oil and gas producing industires in the area, we believe the labor force in the fuel sector is not far from the number in the coal industry with the exception of New York.

State

Md.

N.Y.

Ohio

$\mathrm{Pa}$.

$\mathrm{Va}$.

W. Va.
Total Labor Force (m11110n)

\section{2}

$7.5^{-}$

4.7

5

2

0.7
Fuel Eector 
Taking into account the number of people employed in the servicing and fuel processing industries as well as all the dependents, one can see fuel production is an important factor in the economic life of states like Virginia and West Virginia.

$\underline{\text { Revenue and Tax }}$

Information on revenue, for understandable reasons, is often a trade secret and therefore unavailable. The tax structures of various states are discussed here.

Maryland

Both coal and gas producers are required to pay these taxes: a state corporate income tax at a rate of $7 \%$ of net income, a local real estate tax on the land if it is owned by the producer, and a local tax on tangible personal property, such as equipment and buildings, at a rate of roughly $\$ 2$ per $\$ 100$ of assessed value, depending on locality. Since July 1976 a surcharge of $15 \mathrm{c} /$ ton has been impoased on coal for the explicit purpose of land reclamation.

New York

Oil and gas producers pay the following taxes: a local real estate tax and a state tax. The state tax on an incorporated producer is a corporate franchise tax of $10 \%$ of net income with a minimum annual tax of $\$ 250$. The state tax on unincorporated producer is a business tax of $5 \frac{1}{2} \%$ of net income and no tax if.the annual net income is less than about $\$ 5000$.

Ohio

Coal, oll and gas producers basically pay two kinds of taxes in Ohio: a severance tax collected by the state and a real estate tax by the counties. The former has a unfform rate applied throughout the state: coal at $4 \mathrm{c} /$ ton, ofl at $3 c /$ barrel and gas at 1c/thousand cubic feet. Of the 4 million dollar severance tax the state collected last year from all types of minerals, coal's share 1s about $45 \%$, gas about $20 \%$ and o1l over $6 \%$. The real estate tax rate varies from county to county and no statewide figures are avallable to us. But judging from the overall taxable real estate values of 35 blllion dollars and the total mineral value of coal, o1 and 
gas of 32 million dollars, and from the total real estate tax of 1.6 billion dollars, we believe that coal, oil and gas producers as a whole may be paying one to two million dollars real estate tax a year.

\section{Pennsylvania}

Coal, o1l and gas producers in Pennsylvania pay a $9 \frac{1}{2} \%$ corporate tax on net profit. There is no severance tax.

Virginia

The types of taxes paid by coal, oil and gas producers in Virginia are: corporate income tax, property tax and severance tax. The severance tax is collected at a rate, depending on the county, of up to $1 \%$ of the gross receipts. In 1975, this tax along amounted to $\$ 4$ million.

\section{West Virginia}

West Virginia has a simple tax structure. Coal, oil and gas producers pay a business and occupation tax to the state at a rate of $3.85 \%, 4.34 \%$ and $8.63 \%$, of the gross receipts, respectively. The state then distributes $10 \%$ of such tax revenue to all the counties, $7.5 \%$ to the producing counties and $2.5 \%$ to the non-producing counties. Producers are also required to pay a corpate income tax, which is $6 \%$ of the net income. But due to the business and occupation tax credit, the corporate income tax usually amounts to a very small amount or even nil. No sales tax or severance tax is Imposed.

\section{Bituminous}

Maryland

Buffalo Coal Company

Bayard, W. Va. 26707

Moran Coal Company

Westènport, Md., 21562

Winner Bros. Coal Company

243 Upper Conso1, Frostburg, Md. 21532

Ohio

Consolidated Coal Company

3300 One Oliver Plaza, Pittsburgh, Pa. 15222

Central Ohio Coal Company

P.0. Box 18, Bowling Green Station, New York, N.Y. 10004 
Peabody Coal Company

301 North Memorial Drive, St. Louis, Mo. 63102

North American Coal Corporation

12800 Shaker Blvd., Cleveland, Ohio 44120

Youghiogheny and Ohio Coal Company

4614 Prospect Ave., Cleveland, Ohio 44103

Pennsylvania

U.S. Steel Corporation

600 Grant St., Pittsburgh, Pa. 15230

Bethlehem Mines Corporation

701 E. Third St., Bethlehem, Pa. 18016

C \& K Coal Company

29 North 5th Ave., P.0. Box 69, Clarion, Pa. 16214

Florence Mining Company

P.0. Box 351, Seward, Pa. 15954

Virginia

Pittston Company, Clinchfield Coal Division

Dante, Va. 24237

Island Creek Coal Company

465 East High St., Lexington, Ky. 40508

Beatrice Pocahontas Company

465 East High Street, Lexington, Ky. 40508

West Virginia

Consolldated Coal Company

3300 One Oliver Plaza, Pittsburgh, Pa, 15222

Eastern Assoclated Coal Corporation

Koppers Bldg. Pittsburgh, Pa. 15219

U.S. Steel Corporation

600 Grant St., Pittsburgh, Pa. 15230

Anthrac1te

Pennsylvania

Reading Anthracite Company

200 Mahantongo St., Pottsville, Pa. 17901

Jeddo-Highland Coal Company

800 Exeter Ave., W. Pittston, Pa. 18643 
Blue Coal Corporation

101 S. Main St., Ashley, Pa. 18706

Lehigh Valley Anthracite, Inc.

800 Exeter Ave., West Pittston, Pa. 18643

$\underline{\text { Gas }}$

Virginia

Columbia Gas Transmission Corporation

1700 MacCorkle Ave., S.E.

Charleston, W. Va. 25314

West Virginia

Columbia Gas Transmission Corporation

1700 MacCorkle Ave., S.E. Charleston, W. Va. 25314

Consolidated Gas Supply Corporation

445 West Main St., Clarksburg, W. Va. 26301

Equitable Gas Company

420 Blvd. of the Allies, Pittsburgh, Pa. 15219

$\underline{0 i 1}$

West Virginia

Pennzo11

900 Southwest Tower, Houston, Texas 77002

Quaker Śtate 0il Refining Corporation

11 Center St., 011 City, Pa. 16301 


\section{APPENDIX A}

STATE AGENCIES WITH

ENERGY RELATED FUNCTIONS 
Department of Natural Resources

Te1. 302-678-4506 and Environmental Control

Edward Tatnall Building

Dover, Delaware 19901

Authority

Title 29, Del. Code Chapter 80 - establishment of a

Department of Natural Resources and Environmental Control.

Title 7, Del. Code Chapter 60 as amended July 26, 1974 -

Delaware Environmental Protection Act.

Advisory Councils

Governor's Council on Natural Resources and Environmental Control

Environmental Control

Recreation

Game and Fish

Parks

Soil and water Conservation

Council on Shell Fisheries

\section{Secretary}

Harry E. Derrickson (Acting Secretary)

Appointed by the Governor with the consent of the senate.

\section{Jurisdiction}

The Department is to effectuate state policy by providing for programs for the management of the land, water, underwater and air resources of the state so directed as to make the maximum contribution to the interests of the state, including but not limited to programs for; the control of pollution of land, water, underwater and air resources; for protecting and conservation of land, water, underwater and air resources, and wildife, aquatic life and recreation; fostering research and development to encourage maximum utilization of the state's resources; improving solid waste disposition and; cooperating with federal, interstate, state, local governmental agencies and utilities in the development and utilization of land, water, underwater and air resources.

Planning

Comprehensive water resources plan

Water resources

Quality

Supply

Solid Waste Management

Comprehensive state air pollution control plan

Comprehensive (state) outdoor recreation plan

Hazardous Waste Management

Recreation and park planning 
Research, Management, Monitoring

Develop rules and regulations for the management of:

Solid waste disposal

Water supply and quality

air quality

wetland preservation

beachland preservation

coastal zone management

cooperates with Delaware River Basin Commission in monitoring Delaware River water quality

manages park areas

manages hunting, fishing and shellfishing

radiation

fisheries management

insect control

Regulate, Permit, Certificate

water

Septic tank

Water well construction

NPDES (Federal \& State)

Mineral exploration and exploitation activities

Allocation (withdrawl) wells

Land Use

Coastal construction

Estuarine zone, coastal and tidal wetlands activities Incinerators, process equipment, land clearing, fuel burning equipment

Subaqueous construction and uses

Wetlands

Air

New Source Construction

New Source Operation

Fuel Standards

Radiation control

Boating

Fishing

Hunting

Trapping

Rearing protected game

Dogs

Scientific collectors

Field Trials

(1) Annual Report 1975 
Office of Management,

Budget and Planning

Tel. 302-678-4271

Thomas Collins Bldg.

Dover, Delaware 19901

Authority

Delaware Planning Act of 1961 (29 Delaware Code 4900), Coastal Zone Act of 1971 ( 7 Delaware Code 7001), Executive

order 12 (1 Aug. 1969), and Executive Order 9 (March 9, 1977).

Advisory Council

The Council on state planning

virétor

The Delaware Energy Regource Management Commission ${ }^{1}$

Nathan Hayward III

Appointed by the Governor

Jurisdication

The State Planning office, as part of the Executive Department, is created as the central staff office for state-wide planning in Delaware. Its activities are varied, ranging from Govermental Systems planning, Federal Aid Coordination and Capital Improvements Programming to natural and physical resource planning and local planning aid. In 1976 a variety of energy related activities became part of SPO's responsibilities.

\section{Planning}

Coastal Zone Management

Capital Improvements Program Planning

Human Services Policy and Coordinative Planning

Environmental Policy and Community Development Services

FEA Conservation Program Planning

Research, Management, Monitoring

Energy

Conservation

Technical studies

Federal Aid Coordination (including but not limited to . the following)

Coastal Zone Management

Title IX, Demonstration Cities and Metropolitan

Development Act of 1969 (P.L. 754)

Social and Economic Analysis

Environmental information systems

Land Use

Coastal geology and mineral resources

Hydrology

Regulate, Permit, Certificate

Industrial development in the coastal zone 
This new, 21-member commission's duties include:

-development of a State Conservation Plan;

-development of a educational programs to promote energy conservation

- compiling pertinent data on the State's energy use; and

- recommend changes in State government to effectively coordinate energy policy and plans. 
Public Service Commission

Tel. 302-678-4247

1560 South DuPont Highway

Dover, Delaware 19977

Authority

Title 26, Delaware Code (as amended by Senate Bill No. 469, June, 1974, et sub.)

Commissioners

Lee M. Cassidy

The PUC has five commissioners appointed by the Governor

and confirmed by a majority of the members cleated to the sonate. Each member is appointed to a five year term, no more than three of the members shall be members of the same political party. and, except for one memben at large, the Commissioners shall be selected from (and required to maintain their residence in) different geopolitical units.

\section{Jurisdication}

The Commission has exclusive original supervision and regulation of all public utilities (including water, taxicab, gas, oil, telephone, communications, cable television, and electric companies) and also over their rates, property rights, equipment, facilities, and franchises so far as may be necessary for carrying out the provisions of Title 26.1

\section{Planning}

Nönè

Research, Management, Monitoring

The Commission may promulgate reasonable standards, regulations, practices, measurements and services to be furnished by utilities. It may examine utility property and records and may establish and examine utility accounting procedures.

In establishing rate bases and rate changes llay exallinte alld take into account the efficiency, sufficiency and adequacy of facilities, products and services provided by utilities.

\section{Regulate, Permit, Certificate}

Certificate of Public Convenience and Necessity Initiating Service Extension of Facilities ${ }^{2}$

Approva1

Rates or Tarriffs

Rate or Tarriff changes

Merger, Mortgage or transfer of Property 
Issuance of Securities

Assumption of obligations or debts

1. The Commission has no supervision or regulation over any public utility or over the rates, property, property rights, equipment, facilities or franchises of any public utility that is municipally owned.

2. The Commission may order an extension of utility facilities.

The utilities are not required to secure such a certificate for any extension within the perimeter of the territory already served by $i t$. 
Department of Transportation

Tel. $302-678-4303$

Highways Administrative Bldg.

Dover, Delaware 19901

\section{Authority}

House Bill No. 1230 as amended by House Amendments Nos. 2 and 3, 138th General Assembly, Second Session (Chap. 503, V. 60 signed by the Governor June 30, 1976).

\section{Advisory Council}

The Counc1l on iransportation

Council on Highways

Council on the Transportation Authority

\section{Secretary}

George Jarvis

Appointed by the Governor with the consent of the senate

Jurisdication

The powers and duties of the Department include, but are not limited to, the following activities:

Coordinate in developing, in cooperation with other federal, state and local agencies comprehensive balanced transportation planning and policy for the movement of people and goods within the state;

to be the lead agency for establishing, maintaining and coordinating a comprehensive cooperative transportation planning process;

to be the supervising and responsible staff for all urban and rural transportation studies and programs and enter into any contracts, agreements and stipulations as required;

planning, designing, constructing, operating and maintaining those highways and public transportation systems under its jurisdication and;

establishing, in cooperation with the state Planning office, a rating formula for setting priorities for highways and public transportation projects considering but not limited to the following criteria: sufficiency rating, economic factors, continuity of improvement, social factors, environmental and aesthetic factors, safety factors, and the availability of funds. 
Planning

General transportation program and policy

Safety

Mass transit

Design

Highway

Airport

Research, Management, Monitoring

Safety

Project scheduling

Management systems

Maintenance and specification

design

materials

flow

Subdivision zoning and design

Right of way development (including utility rights of way)

Roadside control

Construction

Environmental review

Contract management

Rail studies

Regulate, Permit, Certificate

hauling permits

outdoor sign permits

junkyard licenses

Public Carriers

Certificate of Public Convenience and Necessity

Rate Approval

Entrance Permits

Utility Permits

Utility Franchise. 
Department of Economic and Community Development Tel: 301-267-5176 2525 Riva Road

Annapolis, MD 21401

Division of Economic Development Industrial Development Financing Authority

Community Development Administration

Division of Housing

Division of Historical and Cultural Affairs

Diviaion of Markel Development

Division of Tourist Development

\section{Associated Boards and Commissions}

Economic and Community Development Advisory Commission

Advisory Commission on Atomic Energy

Commission for Latin American Affairs

Development Credit Corporation

Advisory Commission on Industralized Buildings and Mobil Homes

Code Enforcement Certification Board

ocean City Convention Hall Commission

\section{Interstate Commissions or Boards}

Southern Interstate Nuclear Board

Appalachian Regional Commission

\section{Auliurity}

Ännotated Code of Maryland (1957 and 1974 Cummulative

Supplement) Article 41, Sections 144, 181-181kA, 257-266FF-4, 356, 359A, 364-374, 396-406, 412-429, 438-446; Article 19, Section 42; Nat. Res. Article, Section 3-303, 3-305; Article 78A, Section 13B, 14A-B; Article 880, Sertion 24; Article 66B; Section 8.03, Ref. Chap. 527, Acts of 1970.

Secretary - Joseph G. Anastasi Appointed by the Governor with the advice and consent. of the senate.

\section{Jurisdiction}

The Department was created for the general purpose of advancing the economic and cultural welfare of the people of Maryland. The Department is to investigate and assemble information pertinent to 
Dept. of Economic and

Community Development (Cont'd)

the economic development, industrial opportunities and resources of the State; encourage industrial location or expansion in the State; encourage development of recreation and tourism; and carry out the Governor's policies in such matters (Chap. 527, Acts of 1970).

$\underline{\text { Planning }}$

ODP economic development planning

DMD market development planning

CDA Community project.planning

Energy conservation planning (re. housing codes)

Research, Monitoring, Management

Comprehensive energy data bank

State-wide economic/social energy data center

Economic development studies (gross state and sectoral)

Business opportunity studies

Marketing studies

Housing trend studies

Develop and refine a housing demand model

Administer financial and technical assistance for homes

(Maryland Home Financing Program Article 41, Sections 266FF-266FF-4) and housing (Maryland Housing Fund Chap. 669 Acts of 1971).

Offer financial and technical assistance for industrial Development through the Maryland Industrial Development Financing Authority (Article 41, Sections 266J-266CC) and the Development Credit Corporation Chap. 822 Acts of 1959.

Regulatory

Industrialized Buildings and Mobile Homes Code Div. Housing (Chap. 662 Acts of 1971) Model Performance Code (Chap. 663 Acts of 1971) Code Enforcement - certifies code enforcement Personnel Certification Board 
Energy Policy Office

Tel: (301) 383-6810

Suite 1302

301 West Preston st.

Baltimore, MD 21201

Director - John P. Hewitt

Appointed by the Governor

\section{Jurisdiction}

The EPO was created by executive order ( 1 Nov. 1973) for the purpose of carrying out the mandatory allocation program and a conservation program. The Governor has ingtrueted the office that its duties are to extend beyond short term contingency measures.

Planning and Management

Supply and demand studies

Conservation Programs

Allocation Management

Contingency planning

Operate an Energy Information System

Coordinate related energy activities of other state departments 
Environmental Health Administration (II

Tel: $\quad 301-383-2740$

201 West Preston St.

Baltimore, MD 21201

\section{Associated Boards and Commissions}

Air Quality Control Advisory Council

Radiation Control Advisory Board

Board of Certification of Water Works

Noise Pollution Control Advisory Council

Drinking Water Advisory Council

Authority

- Annotated Code of Maryland, Vol. 4B, 1971 Replacement Vol.

- 1971 Suppl. Art. 43, Health Sec. 114, 2, 690-706 as ammended, Ref. Chap. 77, Acts of 1969.

Director - Donald H. Noren

Jurisdiction

As part of the Department of Health and Mental Hygiene, the Environmental Health Administration is responsible for implementing regulations, plans, programs and policies necessary to maintain an environment free from hazards or nuisances associated with the quality of air, water, food, drugs; the disposal of sewage and solid wastes; and, radiation and other hazardous substances.

Planning

Develop comprehensive air quality plans

Abatement and compliance plans

Baltimore-Washington Regional Plans

Air pollution episode control

Develop abatement schedules

County comprehensive water and sewage plans

County comprehensive solid waste plans

(1) This office has recently been attached to the Department of Natural Resources. 
Environmental Health Admin. (Cont'd)

Research, Monitoring, Management

Air Mon (automated, telemetered, monitoring system)

Emissions Inventory

Air Quality Data Bank

Inspection of emissions sources

Inspection of water supply and wastewater treatment facilities

Inspection of waste disposal facilities

Chemical and biologic surveillance of community water supplies Wastewater treatment inventory

I Aentification of critical water supply dul sewage areas

Environmental radiation surveillance

\section{$\underline{\text { Regulatory }}$}

Emission Source Construction Permit

Emission Source Operation Permit

Construction permits

water supply facilities

wastewater treatment facilities

National Pollutant Discharge Elimination system Permits

Sewage permits

Solid waste disposal permits

Water supply and wastewater treatment plant operators certificate Radioactive materials licensing 
Department of Natural Resources

Tel. $301-267-1230$

Tawes State Office Bldg.

Annapolis, MD 21401

Associated Boards and Commissions

Advisory Boardí(s) to the Secretary of Natural Resources

Land Reclamation Committee

Scenic Rivers Review Board

Environmental Trust

Program Open Space Committee

Boat Act Advisory Committee

Maryland Environmental Trust

Associated Interstate Boards and Commissions

Interstate Commission on the Potomac River

Potomac River Fisheries Commission

Susquehanna River Basin Commission

Ohio River Basin Commission

Atlantic States Marine Fisheries Commission

Interstate Oil Compact Commission

Interstate Mining Commission

Authority

- Natural Resources Article, Sec. 1-10 (inclusive), Chap. 348 Acts of 1972.

Secretary - James B. Coulter

Appointed by the Governor with the advice and consent of the senate.

\section{Jurisdiction}

The intent of the enabling legislation (as revised, Chap. 348 Acts of 1972) was to provide a state agency capable of reviewing all natural resource plans, programs and policies of local, state, regional and Federal agencies; to coordinate all such activities within the State; to provide for state participation in interstate or Federal programs; and, promulgate policies, plans, programs and rules and regulations for the optimal management of natural resources.

Planning

Water quality management plans

Water supply plans

Regional solid waste plans

Power Plant Siting Program

Wildlife Management 
Dept. of Natural Resources (Cont'd)

Coastal Zone Management Program

Wetlands Program

Waterways improvement

Forest management

Fisheries management

Research, Monitoring, Management

Waterway maintenance

Hydrographic monitoring

Power plant site monitoring and assessment

Park and Forest Administration

Aquatic mortality studies

Drainage surveys

Regional studies

Solid waste disposal

Water supply

Water quality surveys

Identification of point and diffuse pollutant sources

sediment control studies

Flood plain management

Coastal zone studies

Identification of biological and physical resources

Identification of critical areas

Identification of estuarine and marine sanctuaries

Requlatory

Wetlands Permits

Dredging

Fishing

water Construction Permits

Navigable waters

Watcrways

Surface Water Appropriation Permits

Ponds

Damo

Reservoirs

Appropriations for use

Water Quality Permits (State and Federal)

Domestic discharge permits

Industrial discharge permits

Toxic materials certification

Oil Permits

Oil handlers permits

Oil terminal facilities license

Oil vehicle operators certificate 
Dept. of Natural Resources (Cont'd)

Commercial Fisheries permits
Boating Permits
Mining Permits (Coal, and other surface mining)
Deep
Strip
Drilling Permits (Gas and oil)
Well drillers license
Well permits

Wildife Permits

(1) The Maryland Environmental Service (Chap. 240, Acts of 1970) is a public utility enterprise created to regionalize (intrastate) the development of water supply and wastewater treatment systems for the localities and industries of the state. It has the statutory authority to plan, design, finance, construct, operate, and maintain the desired facilities.

(2) The Power Plant Siting Program (Chap. 31, Acts of 1971) is responsible for the administration of a long range electric power plant environmental research program, including the monitoring of existing and proposed sites; the evaluation of proposed sites; and the acquisition of land for sufficient standby sites. 
Public Service Commission

Telephone: $\quad 383-2374$

301 West Preston St.

Baltimore, MD 21201

Organization

office of the secretary

Engineering Division

Transportation Division

Accounting Division

Hearing Examiner Division.

Office of People's Counsel

Associated Boards and Commissions

Occupational Health and Safety Board

Energy Advisor Board

Washington Metropolitan Area Transit Commission

Authority

Annotated Code of Maryland

Article 78 Sections 1-107

1975 Replacement Volume and 1976 Supplement

Commissioner's

5 Commissioners, one of whom shall be the Chairman

( 3 Commissioners shall be full time and the remaining

2 need not be full time)

The Commissioners shall each have a 6 year term

The 3 full time Commissioners, one Term

To expire every two years.

Chairman - Honorable Thomas J. Hatem (full time)

Commissioners - William S. Baldwin (full time)

Michael Darr Barns (full time)

Vacant

Vacant

Jursidication

Utilities and Common Carriers

Railroads

Freight and Express Companies

Bus Companies

Steam boat Companies

Ferry Companies

Taxi Companies

Radio Common Carriers

Taxicabs (Selected Political Subdivisions).

Airline Companies

Gas Companies

Electric Companies 
Public Service Commission (Cont'd)

\author{
Telephone Companies \\ Telegraph Companies \\ Water Systems \\ Sewage Disposal Systems \\ Steam Heat Companies
}

Planning

The PSC's jurisdication does not extend to the planning activities of the Public Service Companies, nor does it participate in the planning activities of other state Agencies.

Research, Monitoring, Management

1) tests gas and electric meters before installation

2) tests gas and electric meters at consumers request

3) tests gas and electricity furnished throughout the state

Regulatory

The PSC is authorized to initiate investigations, hold hearings, and certify or permit matters relative to:

Rates - minimum, maximum, reasonable and structure.

Applications to exercise franchises - transfer, abandonment, issue of stocks, bonds, or securities.

Promulgation of rules and regulations relative to utility or carrier operations

Quality of service

Safety of service

Application to build new generating stations*

Major additions.

Transmission lines (over a certain capacity)

Water systems

Transportation of flammable liquids (including gas pipelines).

Concurrent powers of states to regulate interstate commerce.

*The Municipality of Baltimore is exempted from the need for a certificate when building, maintaining, or operating (for other than municipal purposes) plant for supplying gas or electricity Article 78, Section 53. 
Maryland Department of Transportation

(301) 768-9520

P.0. Box 8755

Baltimore-Washington International Airport

Maryland 21240

Associated Boards and Commissions

State Roads Commission (Right of way acquisition)

Transportation Board of Review

Maryland Transportation Commission

Maryland Transportation Authority

Transportation Professional

Services Selection Board

Board of Airport Zoning Appeals

Baltimore Region Transportation

Steering Committee

Washington Region Transportation

Planning Board

Highway Safety Coordinating Committee

Authority

Ref. Chap. 526, Acts of 1970, Annotated Code of Maryland 1957 (1971 Replacement Volume Art. 41).

Secretary - Hon. Harry R. Hughes appointed by the Governor with the advice and consent of the Senate.

Jurisdiction

A result of a governmental reorganization (House Bill 非1000, 1971), the Department of Transportation under the Secretary of Transportation is designed with the authority to administer and plan a comprehensive, balanced, unified transportation system for the state.

$\underline{\text { Planning }}$

Maryland Transportation Plan

Maryland Aviation System Plan

BWI Airport Master Plan

Baltimore Region Rapid Transit_System

Transportation related portions of air quality plans

Port Development Program

State Rail Plan

Regional transportation planning

Airport noise abatement plans

Baltimore Region Phase II Transit Study

Various municipal, county, regional transportation plans 
Department of Transportation (cont'd.)

Research, Monitoring, Management

Periodic Motor Vehicle Inspection study

Commuter Rail Study

Transit studies for small urban areas

Transit studies for non-urban areas

Regional transportation studies

Transportation needs studies

Statewide goods movement study

Social and economic studies

Environmental impact studies

Baltimore rail freight study

State primary and secondary highway systems

Highway project planning studies

\section{$\underline{\text { Regulatory }}$}

Motor vehicle registration

Driver licenses

Hauling permits

Outdoor advertising

Motor vehicle dealers and manufacturers

School bus inspections

State Aviation Administration (1icenses or registers)

Public-use airports

Aircraft

Board of Airport Zoning Appeals

Hears appeals for variances to 1974 Maryland Environmental Noise Act. The noise act establishes airport noise zones, in which land use not compatible with aircraft noise is prohibited. 
Department of Environmental Protection

Tel: $\quad 609-292-2885$

Box 1390

Trenton, NJ 08625

\section{Authority}

New Jersey R.S. 58: 10-12 as amended by the Environmental Protection Act of 1970, A 887 Chap. 33, Laws of 1970 as implemented by Administrative Order No. 5, December 17, 1970 of the Commission of Environmental Protection.

Commissioner -

David J. Bardin

Appointed by the Governor with. the consent of the Senate.

\section{Jurisdiction}

The Department of Environmental Protection was established in April, 1970 to bring together the operations of state government involved in the conservation, restoration and enhancement of the physical environment. Its responsibilities include resource management and, to an increasing extent, regulation (1).

\section{Planning}

water resources (2)

quality

supply

sales

Comprehensive state air pollution control plans

Comprehensive (State) outdoor recreation plan

Develop an environmental design for coastal areas CAFRA

Major nuclear facility incident response plan

\section{Research, Management, Monitoring}

Develop rules and regulations for the management of:

water supply and quality

air quality

noise (commercial and industrial sources)

radiation 
Department of Environmental Protection (Cont'd)

Coordinator of the Federal Flood Insurance Program Control of oxidants study (with Bell Labs)

Administer Green Acres Program (recreation and conservation) Test and register pesticides

Acquisition of reservolir lands

Manages recreation areas

Manages hunting, fishing and shellfishing

Conducts shellfish and shellfish area surveys

Requlate, Permit, Certificate

Water

Pollution treatment systems and control projects Supply systems

Construction encroaching on the high water mark Riparian use

Land use

In dilineated floodways

Coastal construction (under CAFRA)

Riparian land conveyance

Estuarine zone, coastal and tidal wetlands activities

Air

New source construction

New source operation

Fuel standards

Solid waste disposal

Radiation control

Boating

Fishing

Hunting

Pesticides (use, transportation, storage, sale, disposal)

(1) Annual Report 1974, NJ - DEP pp. 2,4.

(2) Northeastern NJ Metropolitan Water Quality Management Plan. 
Department of Labor and Industry

John Fitch Plaza

Trenton, NJ 08625

Organization

Human Resources Development

Income Security

Labor Relations and Workplace Standards

Administration

Econoinic Development

Business Advocacy

Authority

Title 34, New Jersey Statutes Annotated

Commissioner

John J. Horn (Acting).

Appointed by the Governor with the advice and consent of

the senate.

Jurisdication

The Department was created for the general purpose of advancing the economic welfare of the state by; encouraging commercial growth; providing employment opportunities and security; and, providing for the occupational health and welfare of the people of the state.

Boards and Commissions

E'conomic Development Authority (Ch. 80, P.L. 1974)

Economic Development Council

N.J. Area Redevelopment Authority (Ch. 204, P.I. 1962, C.h. 33, P.L. 1970)

Employment Security Council

N.J. State Board of Mediation (Ch. 100, P.I. 1941, Ch. 32, P.L. 1945)

Public Employment Relations Commission (Ch. 303, P.I. 1968)

Board of Boiler, Pressure Vessel \& Refriqeration Rules (Ch. 134, P.L. 1960, Ch. 213, P.L. 1967)

Advianry noard Carnival Imuscment Ride salety (Ch. 105, P.L. 1975)

Planning

Program Planning

Economic Development

Manpower Development

Wage Replacement

Employment Standards

Policy Development Integration and Implementation 
Department of Labor and Industry (Cont da)

Research, Management, Monitoring

Studies (data)

Economic

Demographic

Labor Market

Energy Supply

Manpower development and training

Vocational rehabilitation and prevention

Unemployment and workmen's compensation

Employment security and labor relations

Tourist promotion

International trade,

Economic Development ${ }^{1}$

Regulates, Permit, Certificate

Employment practice permits

Child labor

Handicapped

Industrial homeworkers

Boiler and pressure vessel permits

Power plant engineer and firemen permits

Manufacture, sale, storage, transportation and use of explosives permits

Carnival - Amusement rides permits

Ski-Life registration

1 In 1974 the New Jersey Economic Development Authority was created for the purpose of providing low interest loans to companies wishing to build new or expanded facilities in New Jersey. 
Department of Public Utilities

101 Commerce st.

Newark, NJ 07102

Tel: (201) 648-2409

Organization

Board of Commissioners

Engineering Division

Division of Rates and Accounts

Division of Common Carriers

Dityision of Audits

Office of Cable Television

Authority

New Jersey Revised Statutes - Title 48 as Amended and

Supplemented (See N.J.S.A. 48:1, et seq.), S.B.3179, July 1977.

\section{Commissioners}

Joel R. Jacobson (Commission President)

Stewart G. Pollock

George H. Barbour

Three, appointed to six year terms by the Governor with advice and consent of the senate.

\section{Jurisdiction}

The Department (through the Board) has general supervision, regulation, and control over all the Public Utilities as defined in N.J.S.A. 48:2-13, and their property, property righta, equipment, facilities and frănchises, as well as mnvers, solid waste, and cable television. ${ }^{2}$

\section{Planning}

Use and conservation of energy

Alternate methods of use of fuel

Long-term plans for storage, use and conservation

of encrgy

Research, Manage, Monitor

sturies and Data supply and demand statistics

state power requirements

solid waste disposal

public movers service

cost of eervice

fuel adjustment

rate and adequacy of service

surveillance of utility earnings

Investigates utility complaints

Requires a uniform system of accounting and periodic audit 
Dept. of Public Utilities

Regulate, Permit, Certificate ${ }^{3}$

Solid waste collection

Enforces emissions standards for autobus diesel engines

Land fill operation

Power plant construction

Transmission line construction

Pipeline construction

public movers operation

cable television

1) As of July, 1977 this Department has become a subdivision of the State Department of Energy.

2) Where a public utility is defined as any individual, company, association, corporporation or joint stock company, their lessees, trustees or receivers appointed by any court whatsoever, their successors, heirs or assigns, that now or hereafter may own, manage, operate or control within the state pipeline, gas, electric, light system, plant or equipment for public use, under privileges granted or hereafter to be granted, by this state or by any political subdivision thereof. (Title 48, Chap. 2, Sec. 13, N.J.S.A.). DPU also has jurisdiction over cable television $(48: 5 \mathrm{~A})$, solid waste $(48: 13 \mathrm{~A})$, and public movers industries, $(48: 22)$.

3). The Commission has explicit authority to certificate by N.J.S.A. 48:2-14 to approve the grants of franchises and privileges by municipalities when it is necessary and proper for public convenience and serves the public interest.

Another interesting aspect of the commissions power is its authority to override local zoning regulations and ordinances, or its (the Localities) refusal to locate a utility, when it is found to be in the best interest of the state. 
State Department of Energy

(201) $648-3290$

101 Commerce St.

Newark, New Jersey 07102

Authority

Senate Bill \#3179 signed July, 1977.

Administrator

Joel Jacobson

Appointed by the Governor with the advice and consent of the Senate.

Jurisdiction

The Department was created at the central state energy agency its specific and complete functions have not been delineated. It is to report back to the legislature by January 1978 on the necessary and proper functions of the Department and other agencies.

Planning

State Master Energy Plan

Conservation Plan

Rcacarch

Undefined, but certainly including energy information systems.

Regulatory

Co-extensive jurisdication over energy facility siting

(See the Department of Public Utilities) 
State Energy Office

429 E. State Street

Trenton, New Jersey 08625

Tel: (609) 292-5733

Authority $^{1}$

P.L. 1974, Chap. 2 and 5; Executive Order No.1, Feb 5, 1974.

\section{Administrator}

Burt Ross

Appointed by the Governor with the advice and consent of

the senate.

\section{Jurisdiction}

The office is responsible for; administering state Fuel Allocation programs; identify and analyzing energy problems and recommending policy actions; coordinating energy policy and planning through the various departments of state. (2)

$\underline{\text { Planning }}$

State Energy Master Plan (1974)

Allocation

Standby energy programs

Research, Management, Monitoring

Monitor government conservation programs

Energy Conservation programs (development)

Allocation

Utility rate structure study

Develop supply and demand projections

Regulate, Permit, Certificate

The office's enabling legislation allows for broad regulatory powers relative to the distribution and sale of gasoline and other forms of fuel. 
1) The State Energy Office was placed in the Puc by Executive order. There is currently a legislative bill, making the office autonomous, awaiting the Governor's signature.

2) The SEO serves as a research and management body for the Cabinet Energy Committee: Chairperson Governor

Vice-Chairperson - Attorney General Department of Environmental Protection Department of Labor and Industry Department of Transportation Department of Community Affairs Public Utilities Commission

State Energy office 
Department of Transportation

1035 Parkway Avenue

Trenton, New Jersey 08625

Authority

Title 27, New Jersey Statutes Annotated, Cumulative Pocket part (The Transportation Act of 1966).

Commissioner

Alan Sagner

Appointed by the Governor with the advice and consent of the Senate.

Jurisdiction

The Department is to develop and maintain; a comprehensive master plan for transportation; efficient and economic transportation services; plans for the preservation and improvement of the commuter rail system; and, cooperate and coordinate transportation activities with those of other public agencies and authorities.

Planning

Transportation Master Plan

Commuter Rail planning

Public Transportation Planning

Facility Planning

Inter-Intra Modal planning

Highway Planning

Research, Management, Monitoring

Studies

Economic

Environmental

Drainage

Hydraulic

Soil

Relocation

Safety

Capital Programs

Mass transit

Operation

Construction

Maintenance

Highway

Design

Construction

Maintenance 
Department of Transportation (cont'd)

Aid to local governments

Commuter Services

Materials control and testing

Requlate, Permit, Certificate (1)

\author{
Licenses \\ Airports \\ Heliports \\ Fixed-base operators \\ Rlght of way acquisltiun \\ Public Transportation Facilities \\ Highway and Transportation. Property Access \\ Outdoor Advertising \\ Junkyard Control
}

1) Title 27, Chap. 1A, Sec. 24.

The Department has authority in respect to the exercise of franchises, including extension, abondonment, enlargement, or curtailment of service, and fares of cärriers under contract to the state.

Title 27, Chap. 1A, Sec. 62.

The powers of the $Y \cup C$ in respect to the elimination of railroad grade croesings and the regulation of bridges over or under rights of way are transferred to the Department of Transportation. 
Department of Commerce

90 Washington Ave.

Albany, New York 12245

Tel: $\quad 518 \rightarrow 474-4100$

Organization

Administration

Division of Economic Development

Division of Economic Research and Statistics

Division of Industrial Sciences and Technologies

Division of International Commerce

Division of Metropolitan Area Operations

Division of Public Information

Associated Boards and Commissions

New York State Science and Technology Foundation

Advisory Council for the Advancement of Industrial Research

and Development

Atomic Energy Council

New York State Job Incentive Board

Office of Minority Business Enterprise

New York Job Development Authority

Economic Development Board

Authority

Chap. 4, Laws of 1944 - Chap. VII-a Cons. Laws; as amended

by Chap. 947, Laws of 1968 .

Commissioner

John S. Dyson

Appointed by the Governor with the advice and consent of the Senate.

Jurisdiction

The Department is responsible for administering the state

Commerce Law, which provides for the general promotion of

business and industry; research and compilation of statistical

data on the economy of the State: development and promotion

of industrial or commercial activities; and applied research

in the fields of atomic energy, space development, marine

sciences, ocean engineering, environmental activities and

other science oriented or advanced technology industry. 
Department of Commerce (Cont'd)

Planning

Industrial Development

Commercial Development

Tourism Development

Small Business Development

Research, Management, Monitoring

Assists in Industrial Location and Expansion site identification

identification of environmental and energy problems coordination with other agencies

Manpower training programs

Job Incenlive pruyralls

Conducts Industrial conservation seminars

Develops and analyzes economic statistics

Performs related studies

The economic impact of rail service loss on industrial

and commercial users.

Evaluation of the affects of energy shortages on business and industry.

Participates as a full party in construction permit and operating license hearings for Nuclear Generating Facilities.

statutory Party to the siting of major generating and transmission facilities.

Performs technical evaluation of safety related systems

and components incorporated in Nuclear Power Facilities.

Coordinates activities of State agencies having

regulatory responsibilities for radioactive materials control.

Provides staff services for New York state Atomic

Energy Council.

1) Page 639, Legislative Manual - New York, 1974, Prepared by the Secretary of state.

This description is rather grandiose, as are others of the

same genre, nonetheless the Department does participate in all

such areas where it serves their over-riding interest - the promotion of business and industry in the state. 
New York State Energy Office

Swan St. Bldg.

Empire state Plaza

Albany, NY 12223

Authority

The Energy Law, Chapter 819, Sec, 2. (Laws, 1976)

Consists of twelve members, five appointed by the. Governor from among persons who are not holders of public office. The other members are the commissioners of the Dept. of Commerce and the Dept. of Environmental Conservation, and the Chairmen of the Consumer Protection Board, the Energy Research and Development Authority, the Public Utility Commission, the Power Authority of the State of New York and the State Energy Office (who shall also serve as the Chairman of the Councill.

Commissioner

James Larocca

Appointed by the Governor with the consent of the senate

Jurisdication

The State Energy office shall:

formulate (and revise) a state energy conservation plan to be submitted pursuant to the Federal Energy Policy and Conservation Act of 1975;

and (upon a finding and declaration by the Governor of an existing or impending energy or fuel supply emergency) allocate energy or energy resources with priority to uses essential to public health and safety, impose restrictions on any wasteful, inefficient, or non-essential use of energy or energy resources, and waive (subject to certain limitations) state and local environmental protection requirements to the extent necessary for emergency use of energy resources not meeting. such requirements.

In addition SEO may:

Promulgate energy use standards for the purchase, lease, use or maintenance of state equipment and buildings;

coordinate state administration of any energy or energy resource programs of the federal government (other than those conducted by NYS ERDA);

act as a central repository and clearinghouse for information on allenergy related matters within the jurisdiction of the office; 
New York State Energy Office

prepare an index of the functions of state agencies relating to energy and energy resources; and;

undertake studies and analysis to determine present and projected energy use, supply and demand within the state. 
New York State Energy Research

and Development Authority

230 Park Avenue

New York, New York 10017

Authority

Title 9 of Article 8 of the Public Authorities Law as amended by Chaps. 366 and 830 of the Laws of 1964; Chaps. $294 ; 420$, and 467 of the Laws of 1968; Chap 976 of the Laws of 1969; Chap. 272 of the Laws of 1970; Chap. 751 of the Laws of 1971; Chap. 402. of the Laws of 1974; Chap. 864 of the Laws of 1975; Chap. 482 of the Laws of 1976.

\section{$\underline{\text { Director }}$}

N. Richard Werthamer appointed by Governor Hugh I. Carey. Confirmed by New York State Senate June 28, 1976.

Members

eleven (three of whom shall serve ex officio), eight of whom are appointed for staggered terms of six years each by the Governor with the advice and consent of the Senate, and two of whom were members of the Authority's predecessor, the ex officio

Commissioner - Department of Environmental Protection Chairperson - Public Service Commission

Chairperson - Power Authority of the State of New York of the eight appointed members; at least one shall be an engineer or research scientist; an economist; a member of an environmental group, a member of a consumer group, and, an officer of an electric utility.

The members are:

Honorable Peter A. A. Berle

Dr. Duane Chapman

* James G. Cline

Honorable James A. FitzPatrick

Honorable Alfred $E$. Kahn

William A. Lyons

David Joseph Richardson

*Dr. David Z. Robinson

Dr. John C. Sawhill

Daniel Schuman

David Sive, Esq.

Dr. N. Richard Werthamer

*Atomic and Space Development Authority and serve as additional members for the duration of their terms. 
Organization

Research, Development and Demonstration

Administration

Pollution Control Financing

Facilities

Jurisdiction

The enabling legislation charges NYSERDA with performing research and development on energy efficiency improvements, and on alternative energy supply technologies, particularly from renewable sources such as solar and wind. The development and utilization of these technologies are designed to "promote the State's economic growth, protect its environmental values and be in the best interests of the health and welfare of the state's population." The goals of the Authority are to obtain and maintain safe, dependable, and economic power and energy for the people of New York State.

Divisions

I. Research

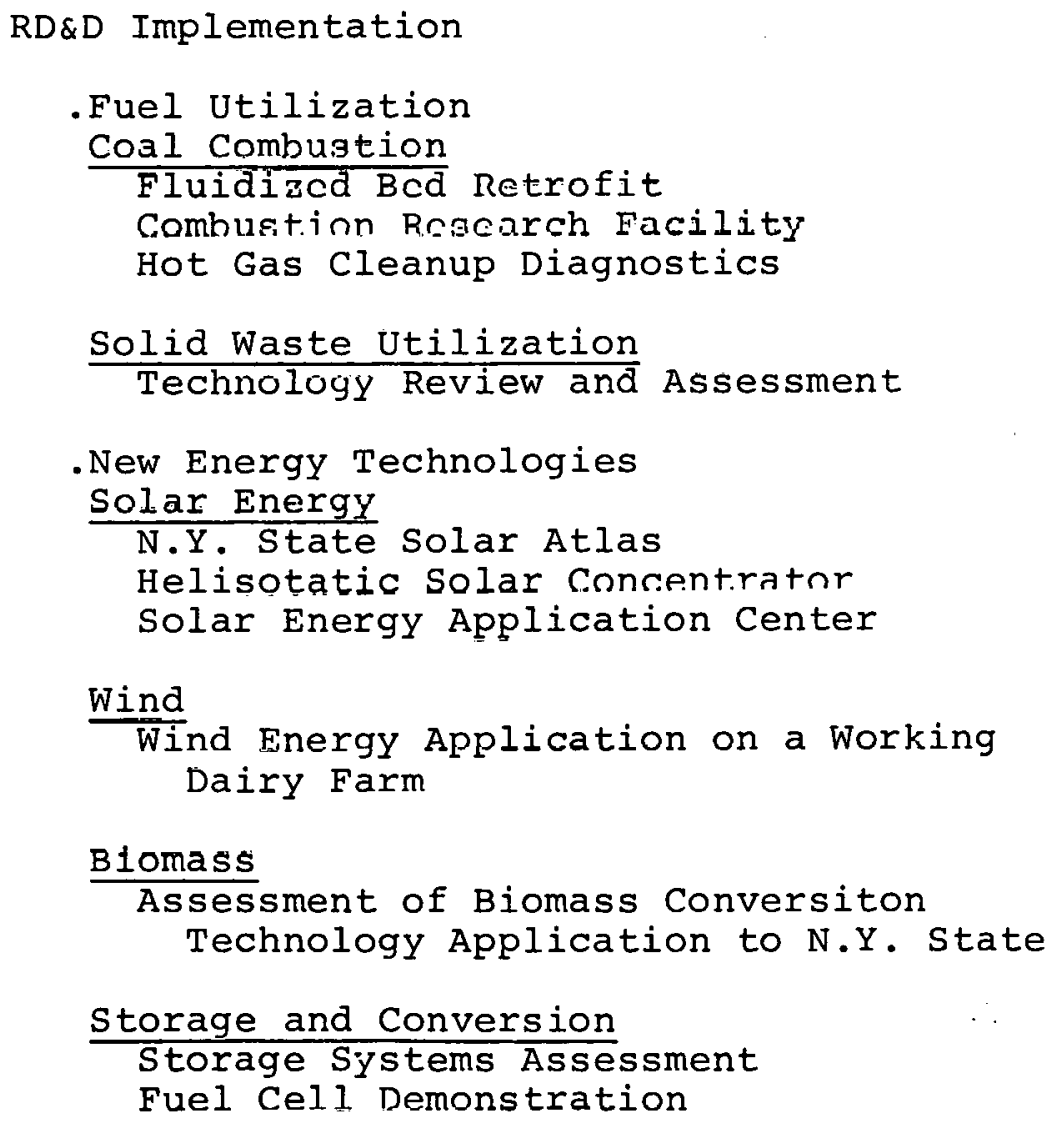

Solid waste Utilization

Technology Review and Assessment

- New Energy Technologies

Solar Energy

N.Y. State Solar Atlas

Helisotatic Solar Concentrator

Solar Energy Application Center

Wind

Wind Energy Application on a Working Dairy Farm

Biomass

Assessment of Biomass Conversiton Technology Application to N.Y. State

Storage and Conversion

Storage Systems Assessment

Fuel Cell Demonstration 
Transmission and Distribution

600 KVDC Cable Development

Compressed Gas Insulation Transformer

Energy Efficiency and Conservation

Technologies

Buildings

Solar Assist Heat Pump Demonstration

Demonstration of Energy Conservation Techniques in a Restaurant

Ballston Spa Central School District

Solar Heating and Hot Water Demonstration

Westchester Solar Hot Water Heating Demonstration

City Wide Retrofit Demonstration

Energy Conservation for N.Y. State Schools

Air to Air Solar Collector Demonstration

Evaluation of Add-on Devices to Existing Gas Fired Equipment

Energy Management Conservation

in Office Buildings

Energy Management Demonstration in

High Rise Residential Buildings

Transportation

Assessment of Energy Conservation

Potential in the Transportation Sector

Industry and Utilities

Low Level Heat Recovery

Combined Electric and Heat Generation

. by a Public Utility

Grid-Connected Integrated Community

Energy System

.Environmental, Health and Safety

Technologies

Power Plant Heat Rejection

Remote Sensing Research

Hydrological Analyses

Thermal Discharge Evaluation

Cooling System Impacts-Power Plant

Intake Structure

Cooling System Impacts -Condenser

Tube simulator

Coal Waste Disposal

Coal Waste Disposal at sea 
Environmental Geology

Seismic and Tectonic Investigations

Radioactive Waste Management

Low Level Radioactive Waste Management

Air Quality

Air Quality Coal Emissions Assessment

Environmental Audit

\section{Planning}

R\&D Planning Analysis and Energy Systems Studies

R\&D Assessment Phase T

$R \& D$ Assessment Phase II

Electric Supply Alternatives Model

for N.Y. State

R\&D Program Planning

R\&D Technical and Information

Dissemination Consultants 
Department of Environmental Conservation 50 Wolf Road

Albany, New York 12233

Telephone: 518-4561754

Associated Boards and Commissions

Council of Environmental Advisors

State Environmental Board

Agricultural Resources Commission

NYS Soil and Water Conservation Committee

Associated Interstate Boards and Commissions

Interstate Sanitation Commission

Ohio River Basin Commission

Great Lakes Basin Commission

Delaware River Basin Commission

Susquehanna River Basin Commission

New England River.Basin Commission

New England Interstate Water Pollution Control Commission

International Joint Commission

Authority

New York State Environmental Conservation Law, Ch. 140,

Laws of 1970, as amended by $\mathrm{Ch} .277$, Laws of 1971 .

Commissioner

Peter A. A. Berle

Appointed by the Governor with the advice and consent of the Senate.

Jurisdiction

DEC is charged with conserving, enhancing, and protecting the State's natural resources by carrying out the environmental policy of the state and preparing an Environmental Plan for the future which will establish clear priorities.

\section{Planning}

State Environmental Plan

Air

Quality Maintenance

Contingency Control

Complex Source Control

Sound and Vibration 
Dept. of Environmental Conservation (Cont'd)

Water

Quality

Supply

Basin studies (small and Level "B")

Land

Waste treatment management

Mined land reclamation

Recreation (area) management

Solid.Waste Management

Coastal Zone

Wetiands (freshwatar and tidal)

Research, Management, Monitoring

Air

Monitoring

Radiation monitoring

Source inspection

Vehicle emissions testing

Noise monitoring

Water

Dispersion, transport, and chemical studies

Resources studies

Treatment studies

Chemical monitoring

Biological monitoring

Discharge inspection

Set water quality standards and discharge limits Land

Pesticide, toxic substanres, and heavy metol monitoring

Forest land management

Forest insect and disease control

Review of proposed development and facilities

Reviews the siting, of energy generation and transmission facilities

Wetlands

Coastal zone

Flood plain assistance

Wetlands studies and inventories

Administers Llie $\Lambda$ gricultural Districts Law

Fish and wildlife habitat and mortality studies

Wildlife habitat management

Regulatory

Air

New source construction permits

New source operation permits

Variances

Indirect sources 
Dept. of Environmental Conservation (Cont'd)

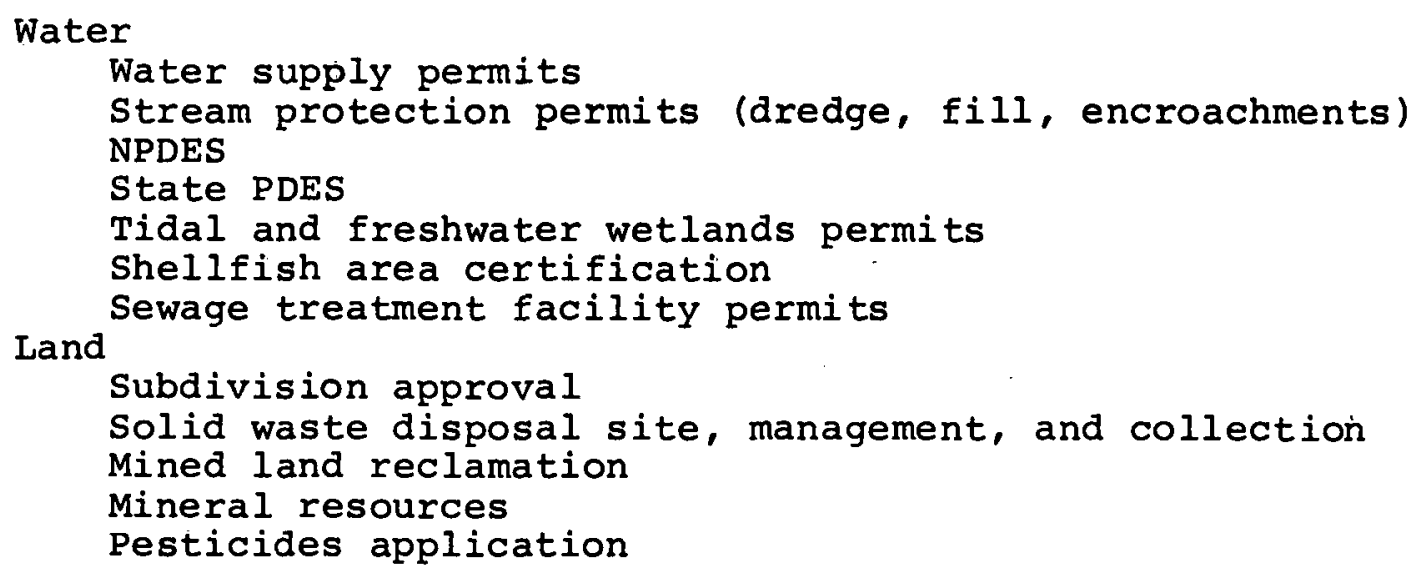

\section{Permits}

New Oil and Gas Well permits

oil and Gas well abandonment permits

Underground Gas Storage permits

Fish and Game Regulation Enforcement

Pesticide Registration

Pesticide use and application permits 
Power Authority of the

State of New York

Rm. 1800

10 Columbus Circle

New York, NY 10019

\section{Authority}

Power Authority Act (Title 1, Article 5 of the Public Authorities Law, Chap. 772, Laws of New York, 1931; last amended by Chap. 482, Laws of New York 1976.) Ma jor amendments: L. 1951, c. 146 authorized construction of Niagara Prnjert; L. 1968 , c. 294 authorized construction nuclear and pumped storage plants; L. 1972, C. 489 authorized construction of base-load plants to serve the Metropolitan Transportation Authority and New York City Transit Authority; L. 1974 C. 369 , 370 authorized acquisition of base-load plants to serve public bodies in the New York City metropolitan area; L. 1975 c. 864 authorized construction of facilities to demonstrate new electric energy generating techniques.

Niagara Redevelopment Act (P.L. 85-159, 71 Stat. 401, 16 U.S.C. $\S \S 836,836 \mathrm{a})$ directed the Federal Power Commission to license the Niagara Project.

\section{'l'rustees}

Appointed by the Governor with the advice and consent of Senate (overlapping five year terms)

James A. FitzPat.rirk - Chairman

George L. Ingalls - Vice-Chairman

William J. Ronan

Richard M. Flynn

Vacant

\section{Jurisdiction}

PASNY is a public corporation of the state created to finance, construct (or acquire) and operate power plants and transmission facilities for purposes sperified in the Power Authority Art and the Niagara Redevelopment Act, which are to assist in maintaining an adequate and reliable supply of electricity for the state of New York and particularly to supply the needs of municipal and rural cooperative electric systems (including some in neighboring states). certain high load factor industries, publit transportation agencies and other public bodies in the New York metropolitan area and other utilities in New York state. 
Power Authority of the state of New York (Cont'd)

Research, Management, Monitoring

Operational Facilities

Niagara Project (hydroelectric)

St. Lawrence Project (hydroelectric)

Blenheim-Gilboa Pumped Storage Power Project

James A. FitzPatrick Nuclear Power Plant

Astoria 6 (oil fired)

- In ia point 3 (nuclear)

Construction program

Arthur Kill (fossil fuel, application filed with NYPSC)

Greene County (nuclear, applications file with NRC and NYPSC)

Prattsville (pumped storage, application filed with FPC)

Transmission facilities - $765 \mathrm{kv}$ transmission line and related facilities to import hydroelectricity from Quebec (under construction)

Safety and environmental studies related to plant design and siting

Radiation, water quality and air quality monitoring (on and off site)

\section{$\underline{\text { Planning }}$}

Site selection

Transmission planning

Participaton with other utilities in state-wide long-range planning pursuant to \$149-b of the New York Public Service Law and in regional planning through the Northeast Power Coordinating Council and the National Electric Reliability Council.

\section{Regulatory}

Regulation: of the rates, services and practices of municipal electric and rural electric cooperative customers. 
Public Service Commission

Empire State Plaza

Albany, New York 12223

Telephone: 518-474-2528

\section{Organization}

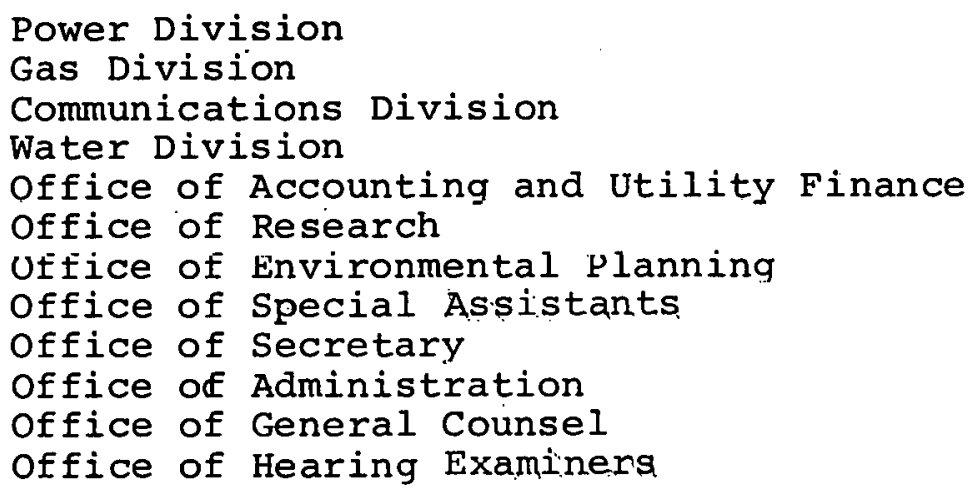

\section{Authority}

Consolidated Laws of the State of New York, Chap. 48, The Public Service Law.

Commissioners - 7, six year terms. The Commission is bi-partisan, with no more than four of its members to be from the same party (1). The Commissioners are appointed by the Governor with the advice and consent of the Senate.

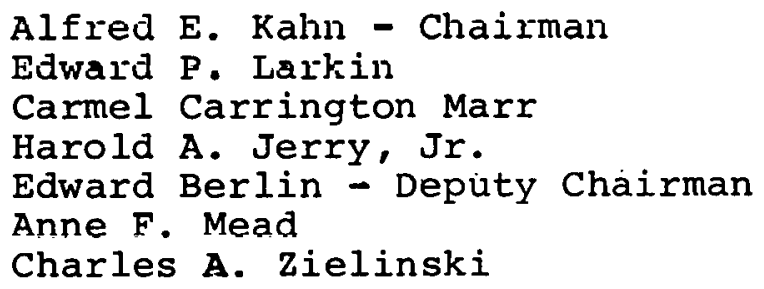

\section{Jurisdication}

'lhe PSC regulates public utilities operating within the state and has jurisdiction over the rates, service and planning of all electric, gas, steam, telephone, telegraph and water works corporations. 
Public Service Commission (Cont'd)

Planning (2).

Requires long range (10 yrl planning for state wide electric generating and transmission facilities (1.49 B) and gas and telephone utilities by the utilities.

Requires the development of contingency plans

Sponsoring conservation studies

Conducting a power plant site survey

Conduct hearings on economics of fossil vs. nuclear

fueled generating facilities

Analyze present and future capability of transmission. systems

Evaluate generation reserve margins

Investigate the adequacy of utility fuel storage capacity

Evaluate emergency procedures for load shedding.

Research, Monitoring, Management

The Commission may hold hearings and initiate investigations in matters related to:

Safe and adequate service

Rate changes

Accounts and audits

Routing or undergrounding of transmission lines

The exercise of franchise

Rules and regulations (established by the Commission)

Regulate, Certificate, Permit

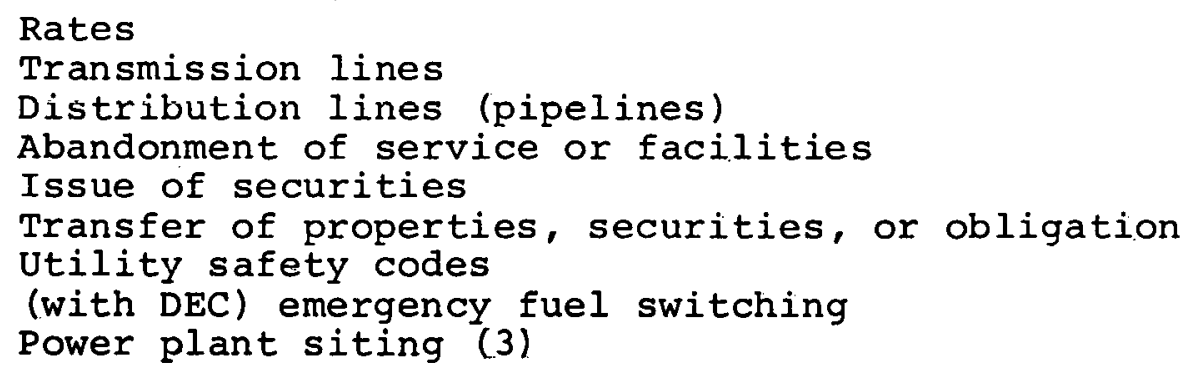

(1) The membership of the Commission has been increased from 5 to 7 members to provide for consumer representation. I. presume the restrictions on political party membership reflect that change. The commission shall consist of five members, to be appointed by the governor, by and with the advice and consent of the senate. A commissioner shall be designated as chairman of the commission by the governor to serve in such capacity at the pleasure of the governor or until his term as 
Public Service Commission. (Cont'd)

commissioner expires whichever first occurs. No more than three commissioners may be members of the same political party unless pursuant to action taken under subdivision two, the number of commissioners shall exceed five and in such event no more than four commissioners may be members of the same political party.

(2) With the exception of the Power Plant Siting survey most of the planning is done by the utilities and subject to review by the Commission. Acceptance by the Commission of the utilities plans does not constitute endorsement which comes only on a project basis.

(3) The Plant Siting Law (Art. VIII of the Public Service Law) established the N.Y. State Board on Electric Generation Siting and the Environment (membership PSC Chairman, DEC, Commerce, Health, one representative from the site locality) in an effort to consolidate the licensing procedure. 
Department of Transportation

State office Bldg. Campus

Albany, NY 12232

Authority

Chapter 717 Laws of 196i, Chapter 267 Laws of 1970.

Boards and Commissions

Metropolitan Planning Organizations

Commissioner

Raymond T. Schuler

Appointed by the Governor with the advice and consent of the Senate.

Jurisdication

The Department is to; coordinate and develop comprehensive, balanced transportation policy and planning for the state coordinate and assist in therdevelopment and operation of transportation services and facilities; and formulate and revise a comprehensive state-wide master plan for the development all modes of transportation, both public and private administer a public safety program for rail and motor carriers in intrastate commerce; and to direct state regulation of such carriers in the public interest in the matter of rates and service.

\section{Planning}

Statewide Master Plan - State Policy, integrating regional and interregional plans for primary and secondary highways (including automobile traffic, public transit, bikeways and freight servicel, waterways and ports, railroads, and aviation facilities.

Intercity/Interregional studies - concerning the above modes of transportation.

Regional/Metropolitan Studies (Upstate and New York City) predominately highways and public transit planning.

\section{Coordination and Assistance}

Federal Program administration and evaluation Operating and capital assistance

Local financial and technical assistance 
Dept. of Transportation (Cont'd)

Research

Safety Studies (all modes).

Energy Conservation

Environmental Analysis

Design and Construction Studies.

Management and Monitoring

Desiyn, Construction and Maintenance (all modes)

Supervision, inspection and analysis

Regulation and Permit Activities

Property acquisition

Common and Contract Carriers

Safety

Service

Entry

Rates 
(PLEASE CONTINUE ON NEXT PAGE)

$-215-$ 


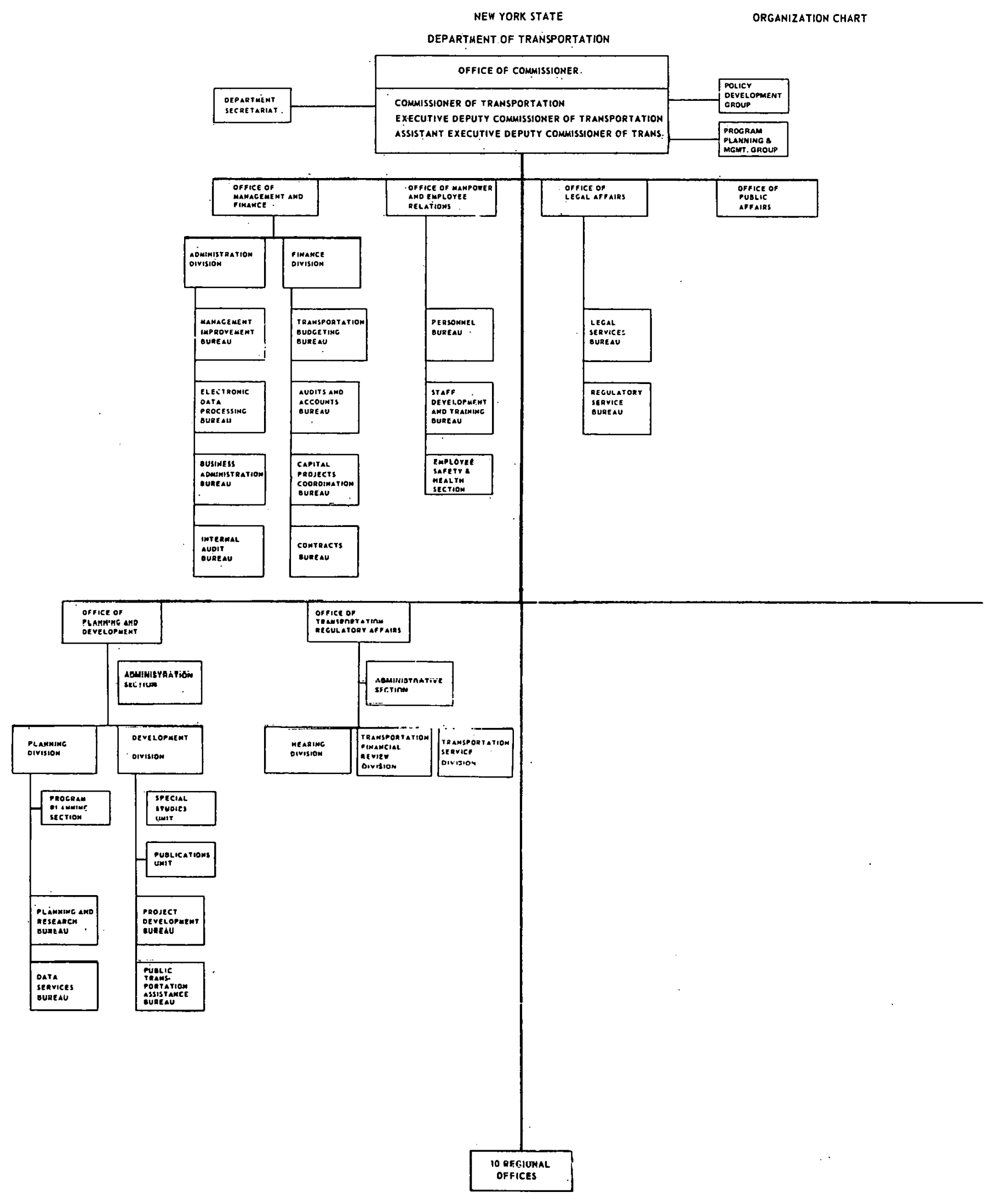




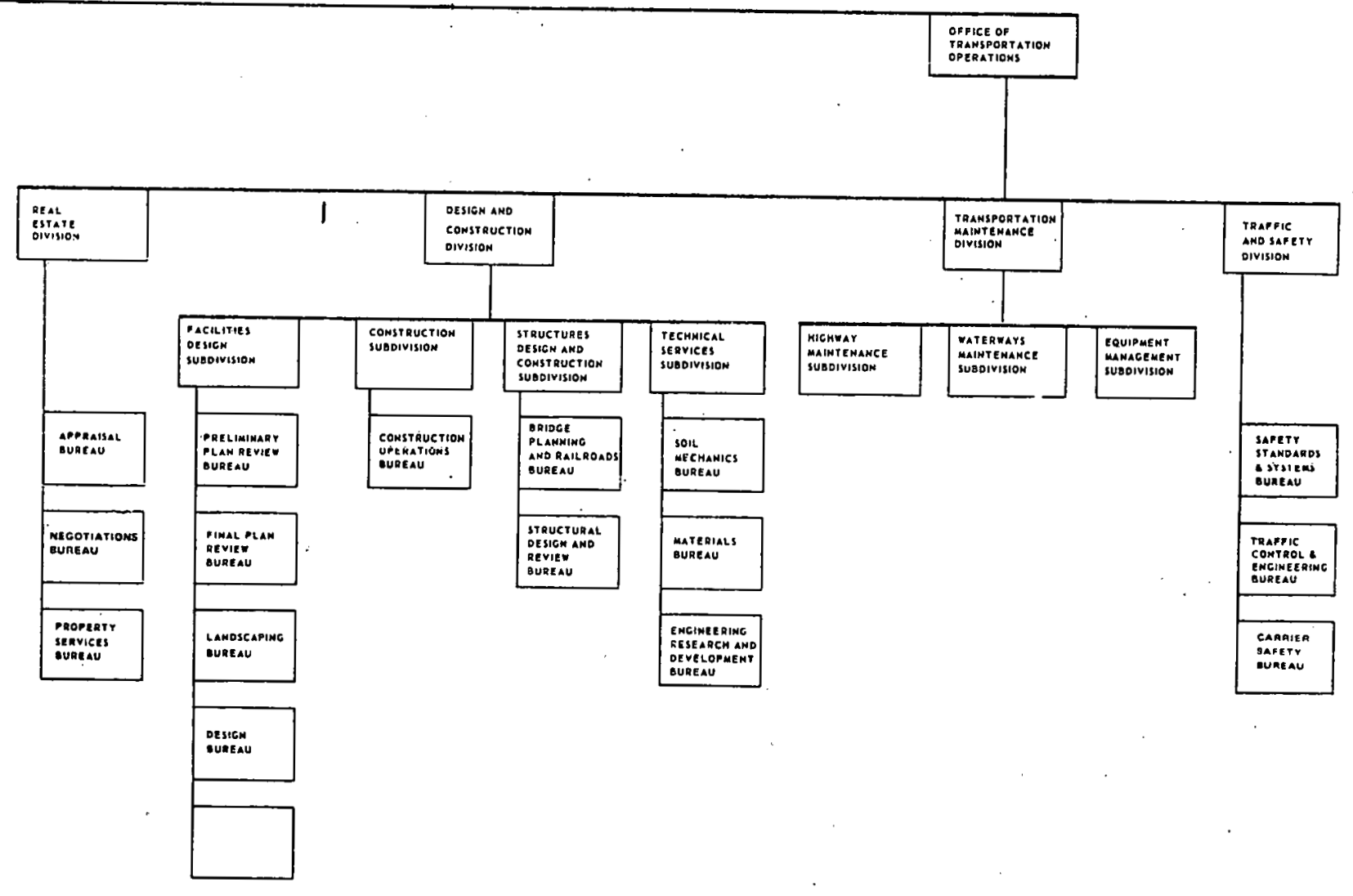


Department of Economic and

Community Development

State office Tower

30 East Broad Street

Columbus, $\mathrm{OH} \quad 43216$

Telephone: (614) 466-2480

Authority

Boards and Commissions

Ohio Development Financing Conulission

Director

James A. Duerk

Appointed by the Governor

Jurisaietion

- The Department shall develop, implement and promote plans and programs designed to ensure that the state resources are efficiently used, economic growth is properly balanced, community growth is developed in an orderly manner, local governments are coordinated with each other and the state, and that community problems are adequately solved.

Divisions

Office of the Dircctor

office of Communications

Office of Program Analysis

Administration of Justice Division

Community Development Division

Economic Development Division

Human Resources Development Division

Planning

Research, Management, Monitoring

Regulate, Permit, Certificate 
Ohio Energy and Resource

Development Agency

30 E. Broad St.

25th Floor

Columbus, OH 43215

Telephone: (614)466-6797

Authority

H.B. 584, signed by Gov. Rhodes on August 25, 1975.

Advisory Councils

Oil and Natural Gas

Utilization and Conservation

Coal

Director

Robert S. Ryan

Jurisdiction

OERDA was created to pull together the fragmented energy responsibilities of various state agencies into a cohesive and comprehensive program to meet Ohio's specific energy problems.

H.B. 584 invested OERDA with a number of substantive responsibilities, including the authority to:

-make grants and enter into contracts for research and studies, or for the construction and operation of energy facilities;

establish an office for energy planning;

collect and analyze energy related data;

develop energy emergency and crisis contingency plans:

give priority to the establishment of one high-

Btu and one low-Btu goal gasification facility;

serve as liaison and advisor on energy matters;

administer the ohio allocation program;

issue energy and resource development revenue bonds and;

seek and receive federal, state, and private funding

for energy programs.

Research Activities

Natural gas stimulation by massive hydraulic fracturing

Shale gas stimulation

Gas and oil exploration in the Cambro-ordovician formations

Shale characterization

Low and medium Btu gas from coal

Statewide energy conservation

Energy seminar for science teachers 
Ohio Energy and Resource

Development Agency (Cont'd)

Program Activities

Implement the Energy Policy and Conservation Act

Energy Data Base (computerized EIS)

Fuel Allocation and energy management

Contingency Planning 
Ohio Environmental

Protection Agency

361 E. Broad Street

P.O. Box 1049

Columbus, $\mathrm{OH} \quad 43216$

Telephone: (614) 466-8565

Authority

PL-92:500, USEPA-Title 40. CFR, National Environmental

Policy Act, Ohio Revised Code

Advisory Councils

Ohio EPA Public Response Group

Director

Ned E. Williams (Appointed by the Governor).

\section{Offices}

Director's office

Assistant Director's office

Environmental Legal Advisor

Environmental Legislative Liaison

Emergency Response

Public Interest Center

Environmental Planning Coordinator

Office of Air. Pollution Control

Office of Wastewater Pollution Control

Office of Operational support

Office of Public Water supply.

office of Land Pollution Control

Office of District Operations

Jurisdiction

The Ohio EPA is the state regulatory agency responsible

for the enhancement and protection of ohio's environment for

the benefit of human health and welfare.

Planning

Contingency planning for pollution emergencies

Public water system

Solid waste recycling

Short and long term environmental planning

Continuous planning process

(208) planning

Research, Management, Monitoring

Evaluation of source performance to support permit system air, water, and sanitary landfill

Mathematical modeling

Field surveillance services

Environmental and technical review (of air, water and solid waste systems). 
Ohio Environmental Protection Agency (Cont'd)

Research, Management, Monitoring (cont'd)

Development of an integrated environmental data base Review of Environmental Impact statements and rules, regulations and standards

Regulate, Permit, Certificate

Air - New Source Permits, Operating Permits, Variance Permits

Water - New Source Permits, NPDES Permit Program

Sanitary landfill licenses

Water Treatment Operator Certificates 
Department of Natural Resources

Fountain Square

1952 Belcher Drive

Columbus, Ohio 43224

Telephone: (614) 466-3770

Authority

Advisory Councils

Forestry Advisory Council

Natural Areas Council

Oil and Gas Board of Review

Parks and Recreation Council

Reclamation Board of Review

Recreation and Resources Commission

Soil and Water Conservation Commission

Technical Advisory Council on Oil and Gas

Unreclaimed Strip Mined Lands

Waterways Safety Council

Wildlife Council

\section{Director}

Robert W. Teater

Appointed by the Governor

Divisions

Forestry

Geological Survey

Lands and Soil

Natural Areas and Preserves

Oil and Gas

Parks and Recreation

Reclamation

Soil and Water Districts

Water

Watercraft

Wildlife

\section{Offices}

Chief Engineer

Business and Finance

General Services

Employee Services

Real Estate

Public Information and Education

Outdoor Recreation Services 
Department of Natural Resources

Page 2

Jurisdiction

The Department is to formulate and put into execution a longterm comprehensive plan for the development and wise use of the natural resources of the state.

\section{$\underline{\text { Planning }}$}

Environmental

Land Use

\section{Research, Management, Monitoring}

Operates and manages state forests, natural areas, preserves and scenic, wild and recreational rivers

Inventories and analyzes state mineral resources including surface and ground water

Soil conservation

Maintains and operates State Park system

Inspection of strip-mine operation and reclamation

coordinates the implementation of agricultural and urban pollution abatement standards

Dam inspection

Acquires land under the Capital Plan

Is responsible for the preservation, propaqation and protection of fish and game

\section{Regulate, Permit, Certificate}

Implements, administers and enforces rules and regulations pertaining to oil and gas field operations

Implements and enforces strip mining laws, issuance of strip mine licenses

Enforces Chapter 1514 of the Ohio Revised Code which rclatea to surface mining of minerals other than cual

Issues dam construction permits (with the exception of those under 10 feet in height or constructed by conservancy districts)

Administers boat licensing and titling laws

Issues hunting and fishing licenses 
Department of Transportation

Transportation Bldg.

25 South Front Street

Columbus, $\mathrm{OH} \quad 43215$

Telephone: (614) 466-2200

Authority

Director

Richard D. Jackson

Appointed by the Governor with the approval of the Senate

Divisions

Finance

Design

Administrative Affairs

Operations

Construction

Research and Development

Field Districts

Jurisdiction

The Department is charged with planning, constructing and maintaining a balanced system of transportation.

\section{Planning}

Transportation

Aviation

Urban mass transit.

Rail transportation.

water transportation

Research, Management, Monitoring

Regulate, Permit; Certificate 
Public Utilities Commission

180 East Broad street

Columbus, Ohio 43215

Telephone: (614) 466-6332

466-3016

Authority

Ohio Revised Code Section 4901.02. Title XIIX of the

Ohio Revised Code.

Commissioners

William S. Newcomb, Jr.

David C. Sweet

C. Luther Heckman, Chairman

Three Commissioners, each serving staggered six year terms

appointed by the Governor with the approval of the Senate.

Divisions

Legal Department

Office of Administration

Utilities Department

Transportation Department

Public Interest Center

Public Information Office

Media Liason

Jurisdiction

The general provisions contained in Title XLIX of the Revised

Code vests the Public Utilities Commission with power and jurisdic-

tion over the following types of utilities: railroads, telegraph and telephone companies, electric liqht companies, gas companies, heating or cooling companies, messenger companies, suburban railroad companies, interurban railroad companies, motor carriers, both common and contract, waterworks companies and sewage disposal system companies.

Planning

Is incorporated within the Utilities Department staff organization.

Research, Management, Monitoring

Conducts rate case hearings

Reviews and analyzes comprehensive utility and transportation policies, proposals and procedures

provides an information clearinghouse for legislative, industrial and consumer advocate groups

Initiate rate investigations 
Requlate, Permit, Certificate

Certificate of convenience and necessity for: initiating electric and gas service

Abandonment of telephone service

Allocate unincorporated territory among utilities

Regulate or control rates to: 1

private consumers (electric, gas and telephone)

suspend proposed rate changes

1

Municipal corporations and utilities can negotiate rates and if they agree, the Commission cannot interfere. If no agreement is reached either party may appeal to the commission which thereafter has complete jurisdiction. 
Department of Commerce

Tel: $\quad 717-787-3003$ 420 South Office Bldg.

Harrisburg, PA 17120

\section{Organization}

Bureau of Economic Development

Bureau of International Development

Bureau of Travel Development

Bureau of Appalachian Development

Bureau of Minority Business Vevelopment

Bureau of Scientific and Technological Development

Bureau of Economic Assistance

Bureau of Personnel and Management Services

Bureau of Fiscal Management

Bureau of Public Information and Advertising

Bureau of Statistics, Research and Planning

Associated Boards and Commissions

Anthracite Committee

PA Council on Urban Economic Development

PA Industrial Development Authority

$\mathrm{PA}$ Science and Engineering Foundation

\section{Authority}

The Commerce Law (P.I. 111), May 10, 1939; Act No. 537, May 17, 1956; Act No. 61, May 6, 1968; Act No. 635, May 31, 1956; and the Community Facilities Act (P.L. 1978), Dec. 22, 1959.

\section{Secretary}

Nancy B. Mawby (Acting)

Appointed by the Goyernor with the adyice and consent of the Senate.

\section{Jurisdiction}

The Department of Commerce is the agency responsible for maintaining Pennsylvania as a ranking industrial state by advancing the growth and stability of business and industry; by preserving and creating working and business opportunities; by improving the states communities as living and working areas; and by assuring that the commonwealth fully shares in the nation's economic growth and expansion. 
Department of Commerce (Cont'd)

Planning

Short term industrial development planning stressing location and site development.

Research, Management

Industrial facilities location

Industrial census

Public utilities census

Energy survey - industrial (fuel, use, amount)

Mining technologies (PSEF)

New coal technology (PSEF)

Coal efficiency studies (PSEF)

Integrated gasification and generation (PSEF)

Coal Information Project (2)

Pennsylvania Technical Assistance Program

(PennTAP BSTD)

(3)

\section{Requlatory}

None

(1) Act No. 416, January 3, 1968 (P.L. 922) authorized PSEF to promote, stimulate, and encourage basic and applied scientific research and development in Pennsylvania.

(2) Under the aegis of BSTD, the Coal Information Project (located at the Penn State Campus); is to computerize technical information in an effort to stimulate and facilitate clean coal fuels development and improved coal combustion systems.

(3) PennTAP offers technical and business information to small businesses. Some emphasis has been placed on energy and a proposal is being prepared to expand this energy service. 
Governors Energy Council

Tel: $\quad 717-787-9749$

410 Payne-Shoemaker Bldg.

Harrisburg, PA 17101

Authority

Executive Order No. 2, February 11, 1974

Membership

Lt. Governor Ernest P. Kline, Chairman

Hon. John O'Connor, Sec. of Commerce

Hon. Louis J. Carter, Chairman, Rublic Utility Commission

Uí. 'I'homas F'ox, Chairman, Governor's Science Advisory Comt.

Hon. Maurice K. Goddard, Sec. of Environmental Resources

Mrs. Katie Everett Johnson, Consumer Relations Officer,

Alleaheny Port Authority

George F. Pulakis. Sec. of Transportation.

Hon. R. Kerstettef, Sec., of Agriculture

Dr. N. J. Palladino, Chairman, Energy Management Panel of Governor's Science Advisory Comt. and Dean of the College of Engineering, Pennsylvania State Univ.

Dr. Rosalind Schulman, Professor of Economics, Drexel Univ. Jack A. Brizius, Director, Office of State Planning and Dev.

Hon. Paul J. Smith, Sec. of Labor and Industry

Hon. William H. Wilcox, Sec. of Community Affairs

Prof. Timothy Scully, Univ. of Scranton, Dep. Pol. Sci.

Hon. John $O^{\prime}$ Connor, Sec. of Commerce

\section{Executive Director -}

William B. HarraI

appointed by the Governor (with the advice and consent of the Council.)

\section{Jurisdiction}

The Council is charged with implementing the control and coordination necessary to insure the proper management of energy use and conservation through the Commonwealth.

\section{Plamning}

Energy system studies

Policy studies

Technical Research 
Department of Environmental Resources

Tel: $\quad 717-787-2814$

P. O. Box 2351

Harrisburg, Pennsylvania 17120

\section{Authority}

Act $275(12 / 3 / 1970)$, Act $222(7 / 31 / 70)$, P.L. 372 (1975), Air Pollution Control Act, as amended, Purdon's Pennsylvania Statutes Annotated, 71 P.S., 1972-1973 Cum. Ann. Pocket Part.

\section{Secretary -}

Maurice K. Goddard

Nominated and appointed by the Governor with the consent of two-thirds of the senate:

Jurisdiction

DER is the central agency responsible for the regulation and development of the Commonwealth's natural resources. The Department combines and coordinates the natural resource planning, management and regulatory responsibilities of several boards, commissions, departments and bureaus under one administration.

\section{$\underline{\text { Planning }}$}

Commonwealth environmental master plan

Comprehensive air pollution control

Comprehensive water quality management planning

Water resourcés management plaps

Coastal zone management plans

Sewage Facilities planning

Solid waste management plans

Soil conservation plan

Forest resource planning

Recreation and park planning

\section{Research, Management, Monitoring}

Coal, oil and gas resounce studies

Alternatiye energy resource development studies

Radiological surveillance program

Air quality monitoring

water quality. monitoring

Reviews (and comments onl. enyironmental imnact studies for federal agencies 
Department of Environmental Resources (Cont'd)

Reviews local water, waste, and solid waste planning

Land acquisition

Forest and recreation management

Develop baseline data for planning activities

Regulate, Permit, Certificate

Air quality and Noise Control ${ }^{2}$

Temporary Operating

Operating

Land Protection

Coal Refuse Disposal Area

Solid Waste Processing and/or Disposal Facilities

Bituminous Coal Mine Surface support

Well Drilling

Well Pillar

Well Plugging

Radiological Health

Use or Possession of non-NRC licensed materials

Use of Radiation Producing Equipment

Surface Mine Reclamation

Drainage

Blaster's Examination

Surface Mining (Coal and non-coal

Water Quality Management

Encroachments

Water Allocation

Dam Construction and Maintenance

Deep Mine Operation

Industrial Waste

Sewerage

Resource Management

occupancy Agreements

Forestry

Prospecting

Seismic Survey

Right-of-way

Fuel Wood

Stone 
Department of Environmental Resources (Cont'd)

Community Environmental Control

Campground and registration

Public Eating or Drinking Place

Bottled Water Dealer

Shellfish Dealer

Migrant Labor Camp

Mobile Home Park

$I_{\text {The Department has the authority to require agreement among }}$ municipalities concerning the joint use of sewerage systems or treatment facilities.

${ }^{2}$ Philadelphia and Allegheny Counties have autonomous air pollution control authorities. 
Public Utility Commission

Te1: $\quad 717-787-5207$

North office Building

Harrisburg, PA 17120

Authority

P. L. 1053, May 1937, Public Utilities Law

P. L. 160 , March 1937

P. L. 215 , Uctober 7, 1976

P. L. 216 , October 7, 1976

Public Utility Law \& Rules contained in Title 52 of Pennsylvania Code

\section{Commissioners}

Five, ten year terms, appointed by the Governor with the advice and consent of two-thirds of all the members of the Senate

Louis J. Carter, Chairman

Robert K. Bloom, Commissioner

Helen B. O'Bannon, Commissioner

Michael Johnson, Commissioner

(Vacancy - as of $4 / 1 / 77$ )

\section{Jurfsdiction}

Companies, corporations or persons engaged in furnishing and of the following services for compensation: natural or manufactured gas, gas and ofl pipeline transmission, water sewerage collection and disposal, electric, steam, telephone, telegraph, radio-telephone communications, common carriers of passengers or property, motor contract carriers and wharf facilities.

\section{Planning}

Requires from the utilities contingency and curtailment planning.

Prepares annual electrical supply forecasts (including customer load, utility capacity, and utility reserve) on a ten year basis.

Requires electric and gas companies to file annual conservation reports.

Commission reviews all proposals for electric and gas company plant expansion. 
Public Utility Commission (cont'd)

Research, Management, Monitoring

Inspection or examination physical properties, materials and facilities gas, water and electric meters operations

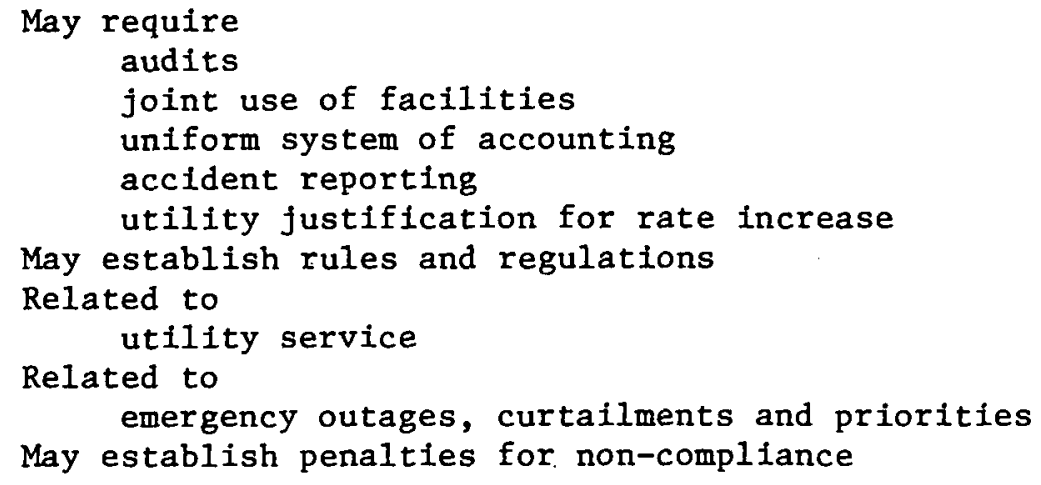

Regulate, Certificate, Permit

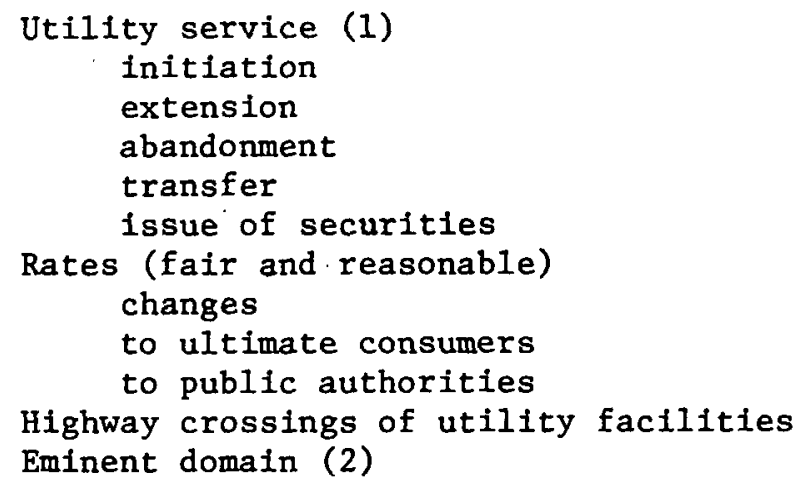

(1) "The history of the PUC has shown that its sole basis for granting certificates has been power supply, rates, and service... There is no requirement for a certificate to be obtained before construction".

Environmental Legislation of Public Utilities (1971), Marjorie Bride, University of Pittsburgh, Graduate School of International and Public Affairs.

(2) After a certificate of necessity has been issued by the regulatory comisision, the landowner may appeal the granting of that certificate to Commonwealth Court, otherwloc, initial condemnation action is taken by the utilities. If any dispute arises between the parties, as to damages, the action is then taken before the Court of Common Pleas. 
Commonwealth of Pennsylvania

Governor's office of State

Planning and Development

510 Finance Building

P. O. Box 1323

Harrisburg, PA 17120

Telephone: 717-787-2086

\section{Authorization}

Established by the Governor in 1971. Subsequently the General Assembly has made annual appropriations to the office, in effect giving it official recognition.

Boards and Commissions

The Pennsylvania State Planning Board is associated with the Office of State Planning and Development. After several years of inactivity the state Planning Board is being reactivated by the Governor and it is his intention that the Board serve in an advisory capacity to him and to the staff of the office of State Planning and Development.

\section{Director}

Jack A. Brizius, appointed by the Governor.

Jurisdiction

The Office of State Planning and Development has statewide jurisdiction as the official state planning agency for Pennsylvania. As a part of the Governor's Office it has contacts with other state agencies and undertakes projects and activities as requested by the Governor.

\section{Divisions}

The Office of state Planning and Development is organized with the following divisions: Administrative Services Division, Economic Development Planning Division, Human Resources Planning Division, Special Projects Division, Natural Resources Planning Division. In addition, there are individuals assigned to the functions of State Planning Board Liaison, Economic Liaison, and Rural Coordinator.

\section{Planning}

The major planning activities of the office of state Planning and Development include the preparation of a State Land Use Policy, the maintenance of the state Recreation Plan, economic development planning, economic and demographic projection studies, human resources planning, and special projects planning based on specific special assignments given to the office by the Governor. 
Commonwealth of Pennsylvania

\section{Research}

Research activities carried on by the Office of state Planning and Development include items relevant to the planning responsibilities listed above.

Regulations

The Office of State Planning and Development has no regulatory activities. 
Department of Transportation

Tel: $\quad 717-787-7357$

Transportation and Safety Bldg.

Harrisburg, PA 17120

Associated Boards and Commissions

State Transportation Commission

State Transportation Advisory Committee

Navigation Commission

Railroad Advisory Committee

Aviation Advisory Committee

\section{Authority}

Act No. 120, May 6, 1970; the Act of April 29, 1959 (P.L. 58); Act No. 7, January 22, 1968; and Act No. 8, January 22, 1968.

\section{Secretary -}

George F. Pulakis (Acting)

Appointed by the Governor with the advice and consent

of the Senate.

Jurisdiction

The Department of Transportation is to develop programs and to assure; adequate, safe, and efficient transportation facilities and services at reasonable costs to the citizens of the commonwealth; and that the planning and development of such services and facilities shall be coordinated by the Department with overall responsibility for balanced transportation policy, research, planning and development.

\section{Planning}

Transportation Policies for Pennsylvania (1970)

Mass transit

Port planning

Prepare six year capital construction plan

Commuter rail system planning

Urban trainsportation planning

State (and Regional) highway planning

Railroad reorgan ization planning

Aviation (and regional air) development planning

Reseärch, Management, Monitoring

General transportation and operator management safety statistics (accident)

Traffic volume studies 
Department of Transportation (Cont'd)

Flow and shipping studies

Railroad and aviation studies

Supervise and control transportation related construction work Enter into contracts for transportation related construction, maintenance and repair

car pooling

\section{Requlatory}

PenDor may promulgate rules and regulations pertaining to intrastate transportation and shipment of hazardous materials

Regulate shipment of hazardous materials

Register motor vehicles, tractors, trailers and semi-trailers

Licenses motor vehicles; tractors

Licenses operators

Licenses river pilots

Licenses aircraft and airports

Establishes size and weight limits (shipping)

Eminent domain (derived from the Constitutional Powers of the State) 
Public Utilities Commission

Tel: $\quad 717-787-5207$

104 North office Bldg.

Harrisburg, Pa. 17120

Authority

P. L. 1053, May 1937, Public Utilities Law

P. L. 160, March 1937

Commissioners -

Five, ten year terms, appointed by the Governor with the advice and consent of two-thirds of all the members of the Senate.

\author{
James M. Kelly - Chairman \\ Robert Bloom \\ Louls J. Carter \\ two vacancies
}

Jurisdiction

Companies, corporations or persons engaged in furnishing any of the following services for compensation: natural or manufactured gas, gas and oil pipeline transmission, water sewerage collection and disposal, electric, steam, telephone, telegraph, common carriers of passengers or property, motor contracl carriers and wharf facilities.

\title{
Planning
}

Requires from the utilities contingency and curtailment planning.

Prepares annual electrical supply forerastis (including customer load, utility capacity, and utility reserve) on a ten year basis.

Resedrch, Manāgement, Monitoring

Inspection or examination

physical properties, materials and facilities

gas, water and electric meters

operations 
Public Utilities Commission (Cont'd)

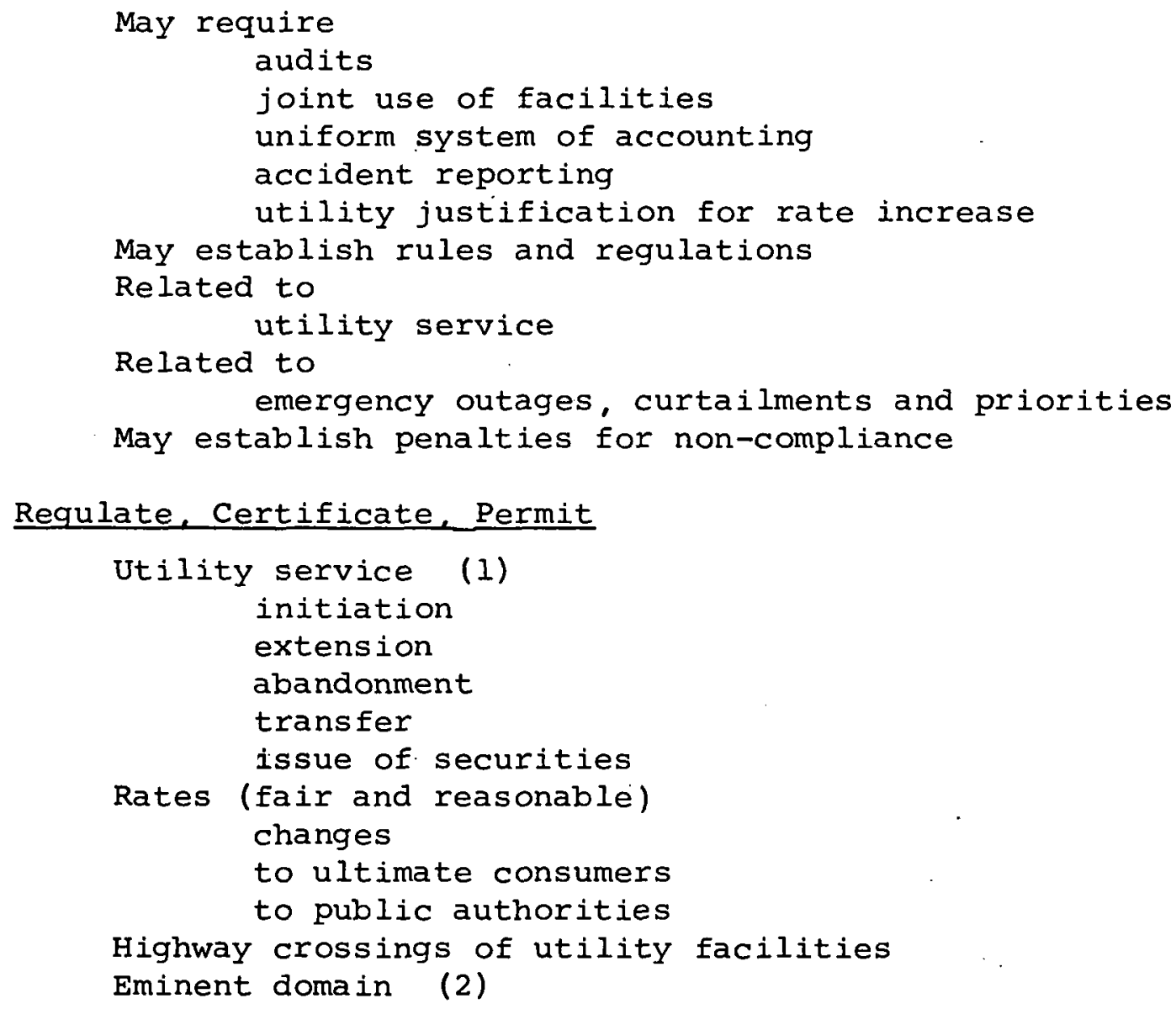

(1) "The history of the PUC has shown that its sole basis for granting certificate has been power supply, rates, and service... There is no requirement for a certificate to be obtained before construction".

Environmental Legislation of Public Utilities (1971), Marjorie Bride, University of Pittsburgh, Graduate School of International and Public Affairs.

(2) After a certificate of necessity has been issued by the regulatory commission, initial condemnation action is taken by the utilities. If any dispute arises between the parties the action is then taken before the court of Common Pleas. 


\section{State Energy Office}

Virginia Energy Office

$823 \mathrm{E}$. Main Street

Room 300

Richmond, VA 23219

Louis R. Lawson, Jr.

$804-770-8451$

State Government Contact For Energy Facility Siting

Division of Public Utilities

State Corporation Commission

P. O. Box 1197

Richmond, VA 23209 .

Ernest Jordan, Ir.

804-786-3614

State Government Contact For Comprehensive Land

Use Planning

Division of State Planning $\&$

Community Affairs

1010 James Madison Building

109 Governor Street

Richmond, VA 23219

Stanley kidwell

804-77 $\theta 4966$

State Government Contact. for Coastal Zone Management

Division of State Planning $\varepsilon$

Community Affairs

Richmond; VA 23219

B. C. Leymes, Jr.

$804-770-7652$

State Government Contact For Environmental Impact

Assessments:

Council on the Environment

Ninth Street State Office Building

Richmond, VA 23219 .

Ms. Susan Wilburn

804-770-2189. 


\section{Virginia (Cont'd)}

State Government Contact For Public Utility Regulation

State Corporation Commission

P. O. Box 1197

Richmond, VA 23209

Ernest Jordan, Jr.

$804-786-3614$ 


\section{West Virginia}

State Energy Office

West Virginia Fuel \& Energy Office

$1262 \frac{1}{2}$ Greenbrier Street

Charleston, WV 25311

John D. Anderson

304-348-886I

State Government Contact for Energy Facility Siting

Department of Planning \& Development

Capitol Building

Charleston, WV 25205

Jeff Herholdt

$304-348-2300$

State Government Contact for Comprehensive Land

Use Planning

Department of Planning \& Development

Robert Gall

$304-348-2246$

State finvernment Contact for Environmental

Impact Assessment

State Clearinghouse

Capitol Building

Charleston, WV 25305

Robert V. Barill

$304-348-3878$

State Government Contact for Public

Utility Regulation

Public Servie Commission

Capitol Building

Clarleston, WV 25305

Brooks [. $3 \mathrm{mit} \mathrm{ll}_{1}$

$304-348-2163$ 


\title{
Virgin Islands
}

\author{
Director of the Budget \\ Justin Moorhead \\ Administers the Virgin Islands Energy Program \\ VI Planning office \\ Director, Thomas Blake \\ Administers Land Use planning, Coastal Zone planning \\ and the Antillean Regional Commission. \\ Department of Conservation and Cultural Affairs \\ Commissioner, Virdin Brown \\ Administers shoreline and earth change permits, \\ environmental assessments, and is scheduled to become the \\ implementing agency for the Coastal Zone Management Plan.
}

* U.S. GOVERNMENT PRINTING OFFICE:1978-0.714-079/11 